\title{
Assessment of Westinghouse Hanford Company Methods for Estimating Radionuclide Release from Ground Disposal of Waste Water at the N Reactor Sites
}

Golder Associates, Inc.

Richland. Washington

Date Published

September 1988

\section{DISCLAIMER}

\begin{abstract}
This report was prepared as an account of work sponsored by an agency of the United States Government. Neithe! the United States Government nor any agency thereof, nor any of their employees, makes any warranty, express or implied, or assumes any legal liability or responsibility for the accuracy, completeness, or usefulness of any information, apparatus, product, or process disclosed, or represents that its use would not infringe privately owned rights. Reference herein to any specific commercial product, process, or service bf trade name, trademark, manufacturer, or otherwise does not necessarily constitute or imply its endorsement, recommendation, or favoring by the United States Government or any agency thereof. The views and opinions of authors expressed herein do not necessarily state or reflect those of the United States Government or any agency thereof.
\end{abstract}

Prepared for the U.S. Department of Energy

Assistant Secretary for Defense Programs

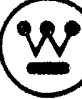

Westinghouse Hanford Company

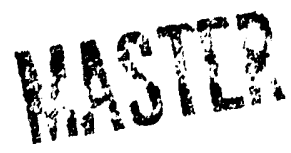

Hanford Operations and Engıneering Contractor for the

U.S. Department of Energy under Contract DE-AC06-87RL10930

\footnotetext{
Purpose and Use of Document This document was frepared for use within the U S. Department of Energy and lls contractors. It is to be used only to pertorm direct, or integrate work under USDOE contracts. This document is rot approved for public release until reviewed.

Patent Status This docimint copy. siyeery is transmilhed in bovance of ortent clearance, is mede avallable in

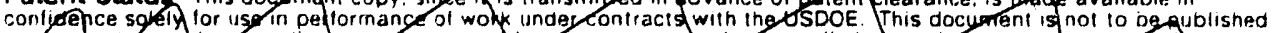

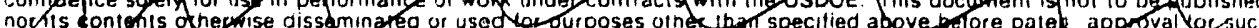
rease by se has been secured. Upon request Irom the USDOE. Patent Attorney. Richland Operationseffice.

Ricnland, WA
} 


\section{CLASSIFICATION/UCNI REVIEW}

TO:

Document Clearance/Processing and Distribution

SUBJECT: Review of WHC.SP-0377

(1) This document contains neither CLASSIFIED nor UCNI material.

This document is CLASSIFIED at the following level and category and may not be released:

$\begin{array}{lc}\stackrel{\text { Level }}{\text { Category }} \\ \square \text { Top Secret } & \square \text { Restricted Data } \\ \square \text { Secret } & \square \text { Formerly Restricted Data } \\ \square \text { Confidential } & \square \text { National Security Information }\end{array}$

This document contains UCNI material and any release must be in accordance with DOE approved distribution lists.
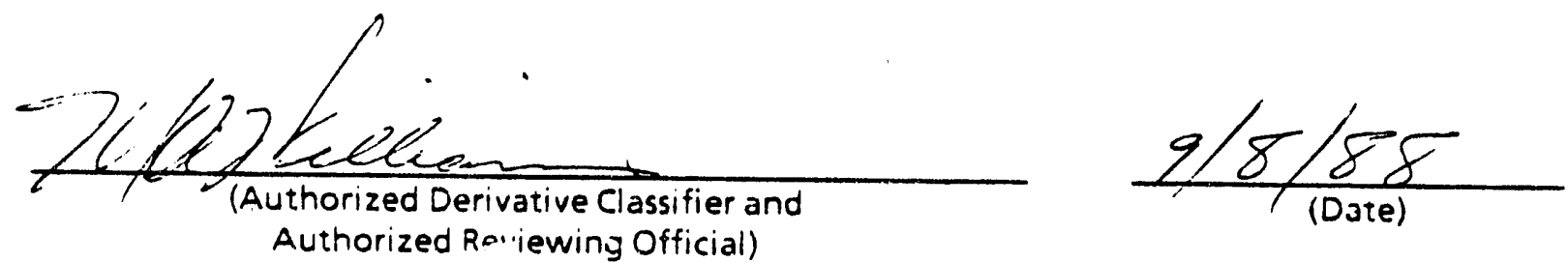

Please submit this completed form and document for distribution to:

Document Clearance/Processing and Distribution

L8-15 


\begin{abstract}
The U.S. Department of Energy has established requirements for the disposal of liquid effluents on the Hanford Site and requires compliance with applicable U.S. Environmental Protection Agency and State of Washington regulations. Although current liquid effluent disposal practices at the Hanford Site are conducted in accordance with U.S. Department of Energy requirements, the continued use of the soil column for the disposal of liquid effluents and the protection of surface and groundwaters are concerns of the U.S. Department of Energy. It is the policy of U.S. Department of Energy to replace the use of soil column disposal practices for radioactively contaminated effluents with alternative waste treatment and disposal methods (U.S. Department of Energy Order 5820.2, 1984).
\end{abstract}

Since monitoring of the release of radionuclides to the Columbia River will continue, Golder Associates was requested to evaluate the current monitoring and calculational method used to determine the release of radionuclides to the river and propose another calculational method for checking the current method for use in the future. They were also asked to propose how the accuracy of the release calculational method could be improved. Finally, they were asked to evaluate the impact of disposal of a lower volume of treated effluent having a reduced temperature and a lower total dissolved solid content at or near the current disposal site. 


\section{EXECUTIVE SUMMARY}

Golder Associates independently assessed the method used by Westinghouse Hanford Company and its predecessors to estimate the annual release of radionuclides to the river from ground disposal of $N$ Reactor plant effluent.

Two alternative and more refined approaches to estimating offsite radionuclide release are presented. The first approach is based on identifying flowpaths from the crib to the river. The second approach is based on a direct computation of flux across a reference release surface. A simplified version of the first approach is applied to a base period of data. The current method estimates a release of $8.6 \mathrm{Ci} / \mathrm{yr}$, whereas the proposed alternative estimates a release of $4.4 \mathrm{Ci} / \mathrm{yr}$. Based on these estimates and the best hydrogeological and engineering judgement, the current calculational method is assessed to be conservative. Recommendations are provided to reduce present uncertainties in estimating radionuclide releases. Most recommendations involve relatively simple field tests and extensions of current activities. They include the following: (1) Obtaining additional hydraulic conductivity information near the river shore in three specific locations, (2) installing two multilevel wells at specific locations, (3) increasing radionuclide sampling on some wells, (4) increasing monitoring of groundwater elevations, (5) expanding $N$ Spring seepage monitoring, and (6) increasing the number of developed monitoring wells, particularly those between the 1325-N facility and the river. 
WHC-SP-0377

The effect of future operational changes on release calculations is evaluated. Discharge of lower flow, lower temperature, and lower total dissolved solids effluent to the far end of the 1325- $\mathrm{N}$ crib has been proposed after the currently designed effluent treatment facility is operational. This would probably reduce the amount of waste water passing beneath the old 1301-N facility, where currently absorbed radionuclides could be readsorbed. It could also increase the ability (because of decreased) of the waste water to mobilize presently adsorbed radionuclides. 


\section{CONTENTS}

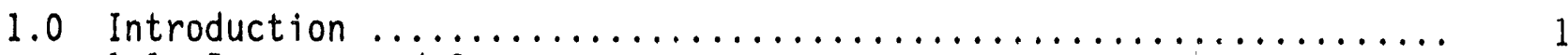

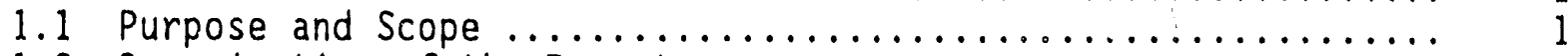

1.2 Organization of the Report $\ldots \ldots \ldots \ldots \ldots \ldots \ldots \ldots \ldots \ldots \ldots \ldots, 1$

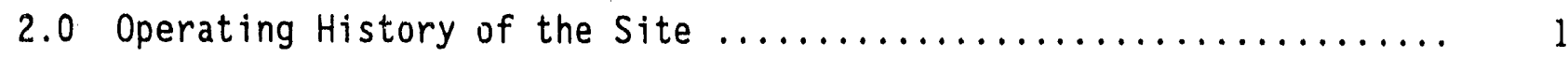

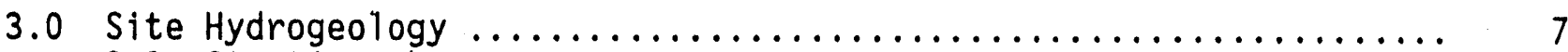

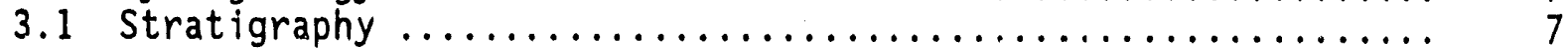

3.2 Hydrology $\ldots \ldots \ldots \ldots \ldots \ldots \ldots \ldots \ldots \ldots \ldots \ldots \ldots, g$

4.0 Assessment of Current Release Calculations .................. 12

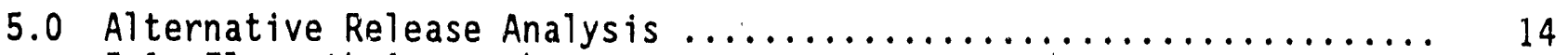

5.1 Flowpath Approach $\ldots \ldots \ldots \ldots \ldots \ldots \ldots \ldots \ldots \ldots \ldots \ldots \ldots \ldots \ldots, 15$

5.1 .1 Analys is of Flux $\ldots \ldots \ldots \ldots \ldots \ldots \ldots \ldots \ldots \ldots \ldots \ldots \ldots, 15$

5.1 .2 Analysis of Activities .......................... 15

5.1 .3 Example Application .......................... 17

5.1 .4 Uncertainties in Analysis ...................... 18

5.1.4.1 Uncertainties in Flux Calculation ........... 18

5.1.4.2 Uncertainties in Activity Calculations ........ 29

5.2 Flux Approach ...................................... 20

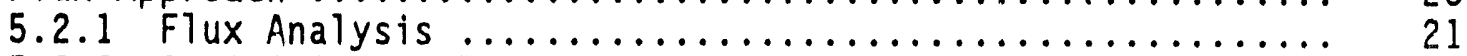

5.2 .2 Activities Analysis $\ldots \ldots \ldots \ldots \ldots \ldots \ldots \ldots \ldots \ldots \ldots \ldots \ldots \ldots, 21$

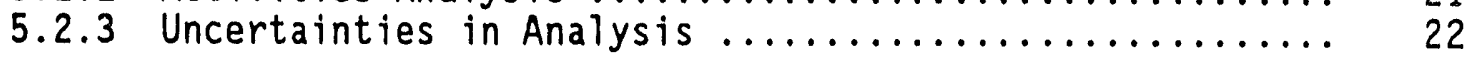

6.0 Recommendations $\ldots \ldots \ldots \ldots \ldots \ldots \ldots \ldots \ldots \ldots \ldots \ldots \ldots, 22$

6.1 Release Calculations $\ldots \ldots \ldots \ldots \ldots \ldots \ldots \ldots \ldots \ldots \ldots, 22$

6.2 Actions to Reduce Uncertainties .......................... 22

6.2.1 Pump Testing .................................. 23

6.2.2 Radionuclide Monitoring Expansion ..................... 23

6.2.3 Radionucl ide Sampling Frequency .................... 23

6.2 .4 Groundwater Monitoring Frequency....................... 23

$6.2 .5 \mathrm{~N}$ Springs Moritoring Network Expansion ............... 23

6.2.6 Water Level Munitoring Network Expansion ............... 24

6.2 .7 Documentation ............................... 24

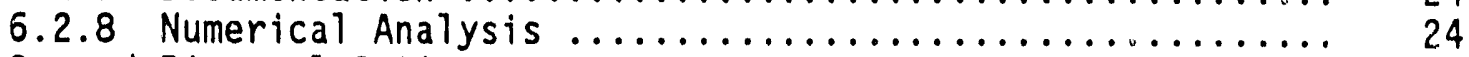

6.3 Ground Disposal Options ................................. 24

6.3 .1 Structurar Options .............................. 24

6.3 .2 Operational Options............................ 25

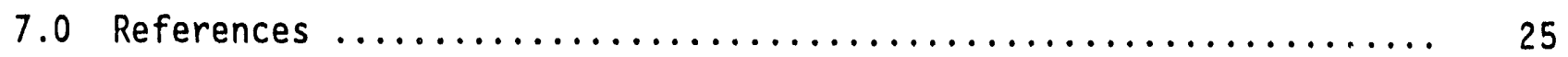

Appendices:

A. N Springs Vertical Profile $\ldots \ldots \ldots \ldots \ldots \ldots \ldots \ldots \ldots \ldots, \ldots, \ldots \ldots \ldots$

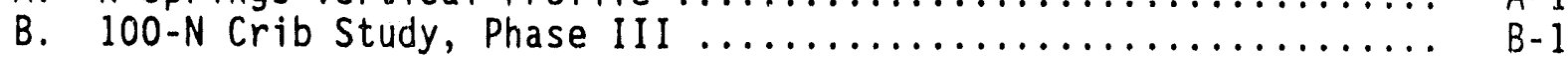




\section{LIST OF FIGURES}

1 Plan of $N$ Reactor Site and Waste Water Disposal Facilities ........ 2

2 Waste water Flow to the $1325-\mathrm{N}$ Facilit! ..................... 3

3 Total Activity in Waste Water Released to 1325-N Facility

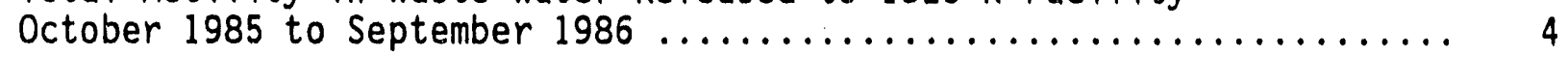

4 Total Activity in Well 8T October 1985 to September $1986 \ldots \ldots \ldots \ldots$

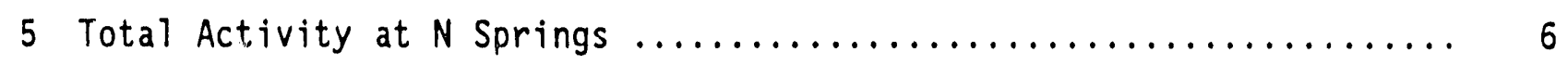

6 Generalized Geologic Cross-Section of $N$ Reactor Area ............. 8

7 Historic Groundwater Tables on the Hanford Site ............... 10

8 Groundwater Levels in the Vicinity of the $N$ Reactor $\ldots \ldots \ldots \ldots \ldots \ldots 11$

9 Potential Groundwater Flowpaths from the $1325-N$ Facility ......... 16

\section{LIST OF TABLES}

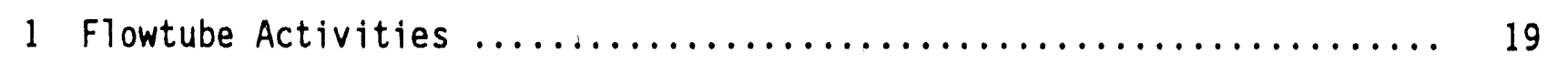


WHC-SP-0377

\section{ASSESSMENT OF WESTINGHOUSE HANFORD COMPANY METHODS FOR ESTIMATING RADIONUCLIDE RELEASE FROM GROUND DISPOSAL OF WASTE WATER AT THE N REACTOR SITES}

\subsection{INTRODUCTION}

\subsection{PURPOSE AND SCOPE}

This report summarizes the results of an independent assessment by Golder Associates, Inc. of the methods used by Westinghouse Hanford Company (Westinghouse Hanford) and its predecessors to estimate the annual offsite release of radionuclides from ground disposal of cooling and other process waters from the $N$ Reactor at the Hanford Site. This assessment was performed by evaluating the present and past disposal practices and radionuclide migration data within the context of the hydrology, geology, and physical layout of the $\mathrm{N}$ Reactor disposal site. The conclusions and recommendations are based upon the available data and simple analytical calculations. Recommendations are provided for conducting more refined analyses and for continued field data collection in support of estimating annual offsite releases. Recommendations are also provided for simple operational and structural measures that should reduce the quantities of radionuclides leaving the site.

\subsection{ORGANIZATION OF THE REPORT}

Historical background information for this study is presented in Section 2.0 as a chronology of key process water disposal events at the $\mathrm{N}$ Reactor. Ser:ion 3.0 describes the generalized near-surface stratigraphy and groundwater conditions at the reactor site. Section 4.0 describes the current analytical methods used to estimate the annual offsite release of radionuclides through the soil-water system and discusses the principal assumptions made. Section 5.0 presents an alternative approach to estimating offsite releases that can serve as a preliminary basis for assessing the adequacy of the methods used by Westinghouse Hanford. Conclusions and recommendations regarding the release calculations are presented in Section 6.0, along with suggestions for future sampling, analyses, and alternative structural and management options that could reduce offsite radionuclide release.

\subsection{OPERATING HISTORY OF THE HANFORD SITE}

The $N$ Reactor is located on the south bank of the Columbia River in the northern part of the Hanford Site in Washington State. Water for reactor cooling, spent fuel storage basins, peripheral coolant systems, and other process systems is drawn directly from the river at the site and is discharged to a covered liquid waste disposal facility. This facility is designed to percolate the waste water into the ground. A plan view showing the pertinent components of the $N$ Reactor facility is presented in Figure 1. 
WHC-SP-0377

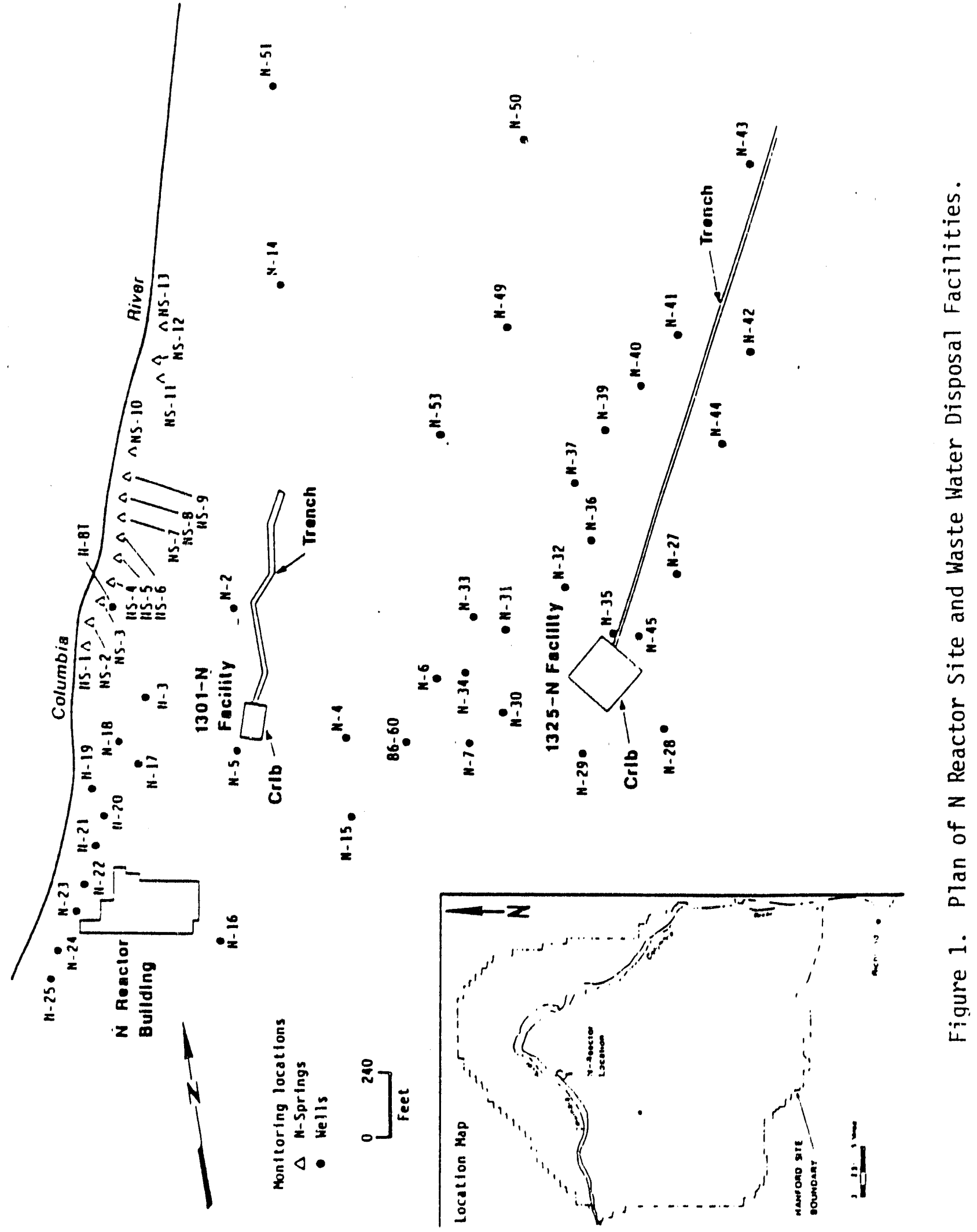


Two liquid waste disposal factlities have been used at the $N$ Reactor. Each facility consists of a pond-like rectangular "crib" with a trench extending from one side. The oldest is the 1301-N facility, which was used from the time the reactor went on line from 1963 unt 11 September 1985. The 1301-N extension trench was built in 1965 because the waste water volume exceeded the capacity of the crib. Boulders were placed in the crib, and later, a concrete cover was placed over the trench to minimize wildlife access and airborne contamination. In 1983, the 1325-N crib was built to augment the original 1301-N facility and started receiving part of the waste water discharge. This new facility was located approximately twice as far from the river as the old facility and is completely covered. In 1985, a covered extension trench was added to the $1325-\mathrm{N}$ crib to increase the capacity of that facility. To enhance percolation, the 1325-N trench and crib were sited in an area that borehole geophysical logs suggested would have a relatively high permeability. Since September 1985, the 1325-N facility is reported by Westinghouse Hanford to be the only facility in use.

The average monthly waste water flow into the $1325-\mathrm{N}$ facility during the 12-mo period from October 1985 through September 1986, when the $N$ Reactor was in normal operation, is shown in Figure 2. This is the base period for comparative analysis of release calculations in this report. During this period, the average waste water flow to the $1325-\mathrm{N}$ facility was $1,410 \mathrm{gal} / \mathrm{min}$ $(5,337 \mathrm{~L} / \mathrm{min})$. Composite sampling is conducted on the waste water discharged into the disposal facility on a weekly basis to determine the activity of the radionuclides in picocuries $\mathrm{ger}$ lifer ( $\mathrm{pCj}$ / $\mathrm{L}$ ). Actiyjty releases are determined for ${ }^{60} \mathrm{Co}, 90 \mathrm{r}, 1{ }^{\circ} \mathrm{Ru}, 106_{\mathrm{Ru}}, 125 \mathrm{Sb}$, and $13 \mathrm{I}_{\mathrm{I}}$. A plot of the total activity of these radiotiements in the 1325-N influent water for the base period is shown in Figure 3. The total dissolved solids (TDS) of the influent water is $-135 \mathrm{mg} / \mathrm{L}$. The temperature of the water ranges from $83^{\circ} \mathrm{F}$ to $105^{\circ} \mathrm{F}$ $\left(28^{\circ} \mathrm{C}\right.$ to $\left.41^{\circ} \mathrm{C}\right)$ and averages $-94^{\circ} \mathrm{F}\left(34^{\circ} \mathrm{C}\right)$.

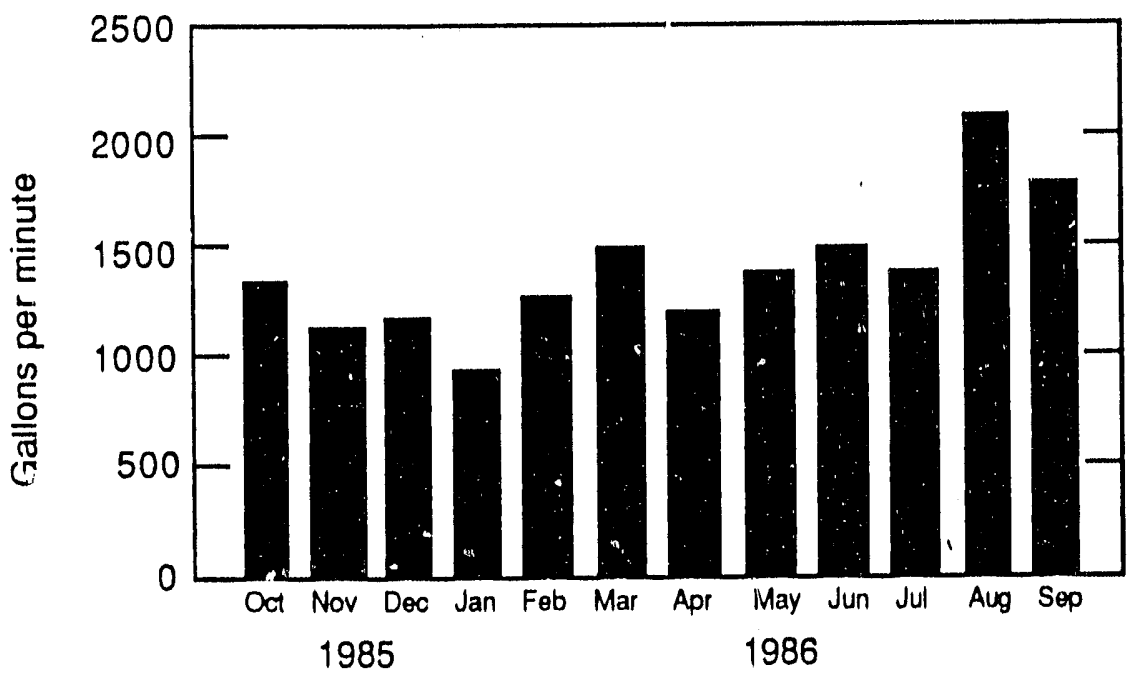

$38804 \cdot 0.33 .2$

Fiaure 2. Waste Water Flow to the 1325-N Facility. 


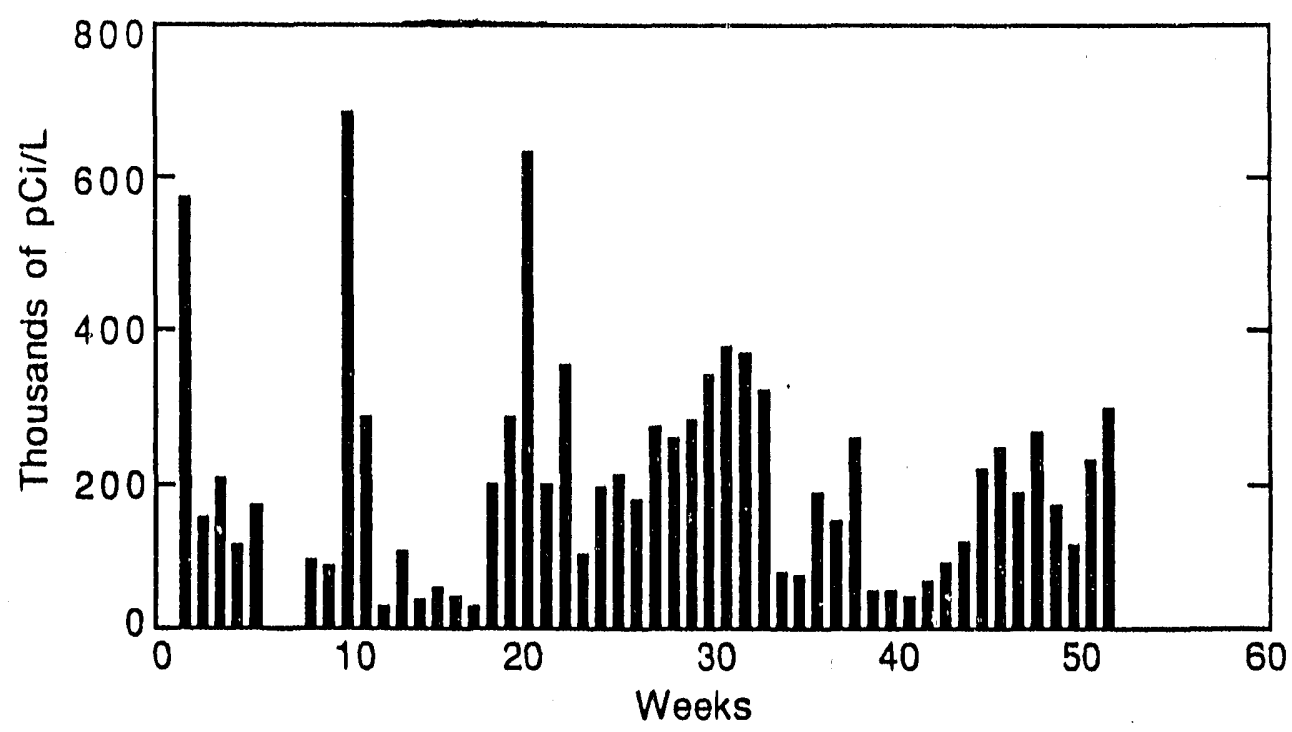

$38804 \cdot 053.4$

Fiqure 3. Total Activity in Waste Water Released to $1325-\mathrm{N}$ Facility October 1985 to September 1986.

Ground disposal of liquid waste permits removal of radionuclides from the waste water through the natural ion exchange and sorptive capacity of the soil and provides retardation time for radionuclide decay. The effectiveness of the soil system in removing radionuclides varies by radionuclide and length of flowpath and decreases over time. Groundwater seeps were observed along the -iver shore near the 1301-N facility after that facility had been placed in operation. These seeps are now known as the $N$ Springs. In 1973, groundwater samples showed that some radionuclides had nigrated through the soil system along the shorter pathways and were entering the Columbia River.

A composite sampling system was installed in 1973 at well $8 T$, which is located $-15 \mathrm{~m}(50 \mathrm{ft})$ inland from the largest of the $N$ Springs. The activities of the six long lived radionuclides measured in the crib influent water are also measured in this well. Radionuclide acti.ities in the well were observed to increase steadily through the years. In 1982, the rate of increase of lodine and strontium activities accelerated, suggesting that the soil was losing its capacity to retain radionuclides and prompting construction of the $1325-\mathrm{N}$ facility in the following year. Once the $1325-\mathrm{N}$ facility was fully used and discharge to the $1301-\mathrm{N}$ facility ceased, radionuclide concentrations in wel1 $8 \mathrm{~T}$ generally decreased. Total activities from the weekly measurements made during the aforementioned October 1985 through September 1986 base period are shown on Figure 4. The TDS of the well water is $-200 \mathrm{mg} / \mathrm{L}$ and its temperature is $-22^{\circ} \mathrm{C}\left(71^{\circ} \mathrm{F}\right)$.

The early sampling wells were periodically supplemented by other monitoring points, which presently total more than 50 (see Figure 1). Some of these wells have been located farther ialland than well $8 \mathrm{~T}$ to provide hydrologic, hydrochemical, and stratigraphic information around the disposal facilities and between the facilities and the river. For example, 10 additional test wells were installed in April 1984 to a depth of $\sim 21 \mathrm{~m}(70 \mathrm{ft})[\sim 6 \mathrm{~m}(20 \mathrm{ft})$ 


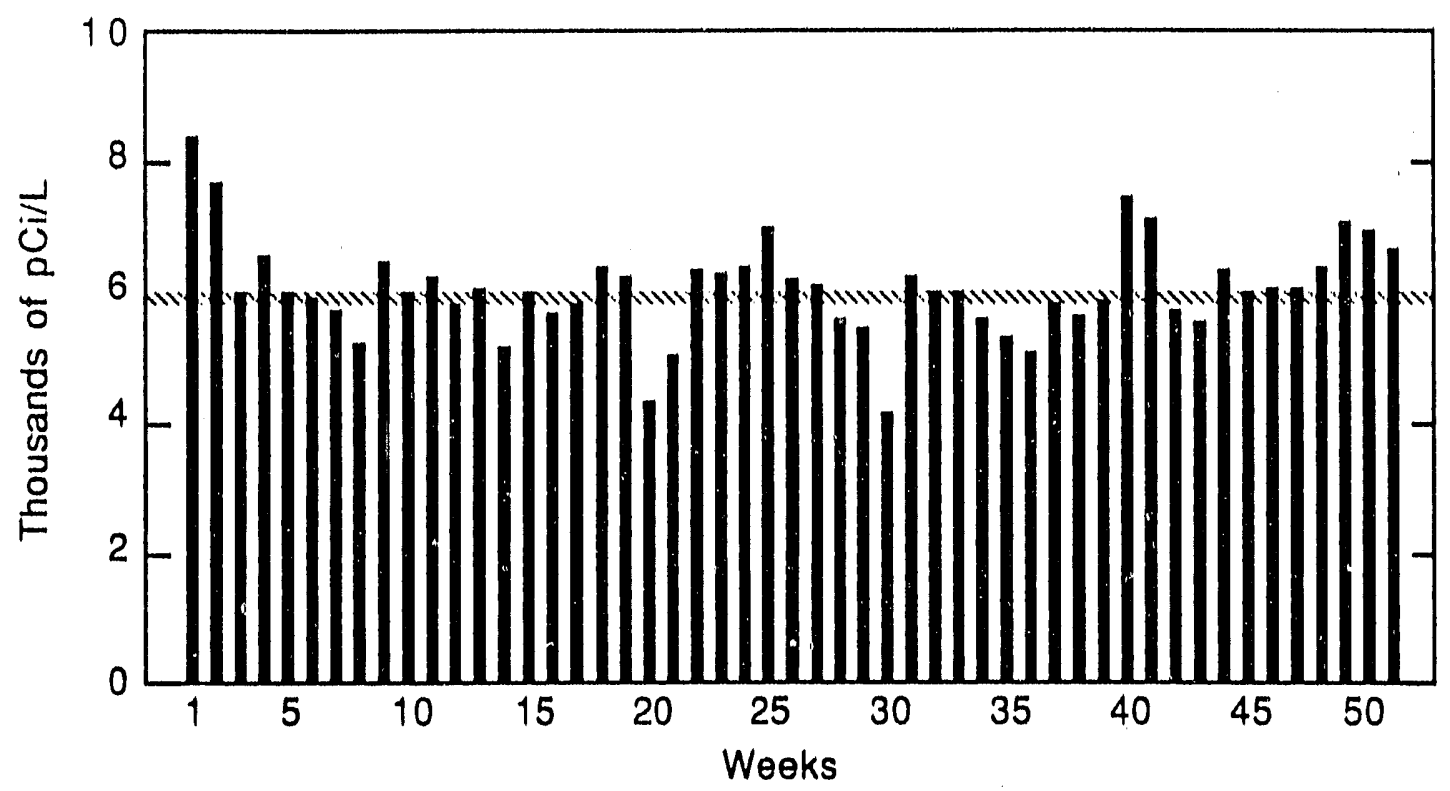

$38804 \cdot 053.3 \mathrm{M}$

Figure 4. Total Activity in Well 8T October 1985 to September 1986.

into the satur?ted zone] in the area immediately adjacent to the $1325-\mathrm{N}$ facility (we1ls N-36 through N-45 in Figure 1). The purpose of these wells was to aid in siting the 1325-N trench and to assure percolation rates would be adequate.

The monitoring points include the $N$ Springs shown in Figure 1 along the shoreline. The total activities of the six aforementioned radionuclides from samples taken in the $N$ Springs in 1984, 1985, and 1986 are shown in Figure 5. Total activity measured in the $8 \mathrm{~T}$ well on the date of $\mathrm{N}$ Springs measurement is also shown on Figure 5 for comparison. These results indicate that radionuclide concentrations in the $8 \mathrm{~T}$ well are among the highest measured along the shoreline. Concentrations of radionuclides in samples collected upstream and downstream from the $8 T$ well are generally lower than those measured in the well itself. The 1984 samples were taken directly from shallow depressions hand dug into the soil at each spring, whereas the 1985 and 1986 samples were taken from shallow wells installed at the spring locations. The distributions of activities along the shoreline appear to be reasonably consistent from year to year, particularly for 1985 and 1986, when essentially identical sampling procedures were used. 
WHC - SP- 0377
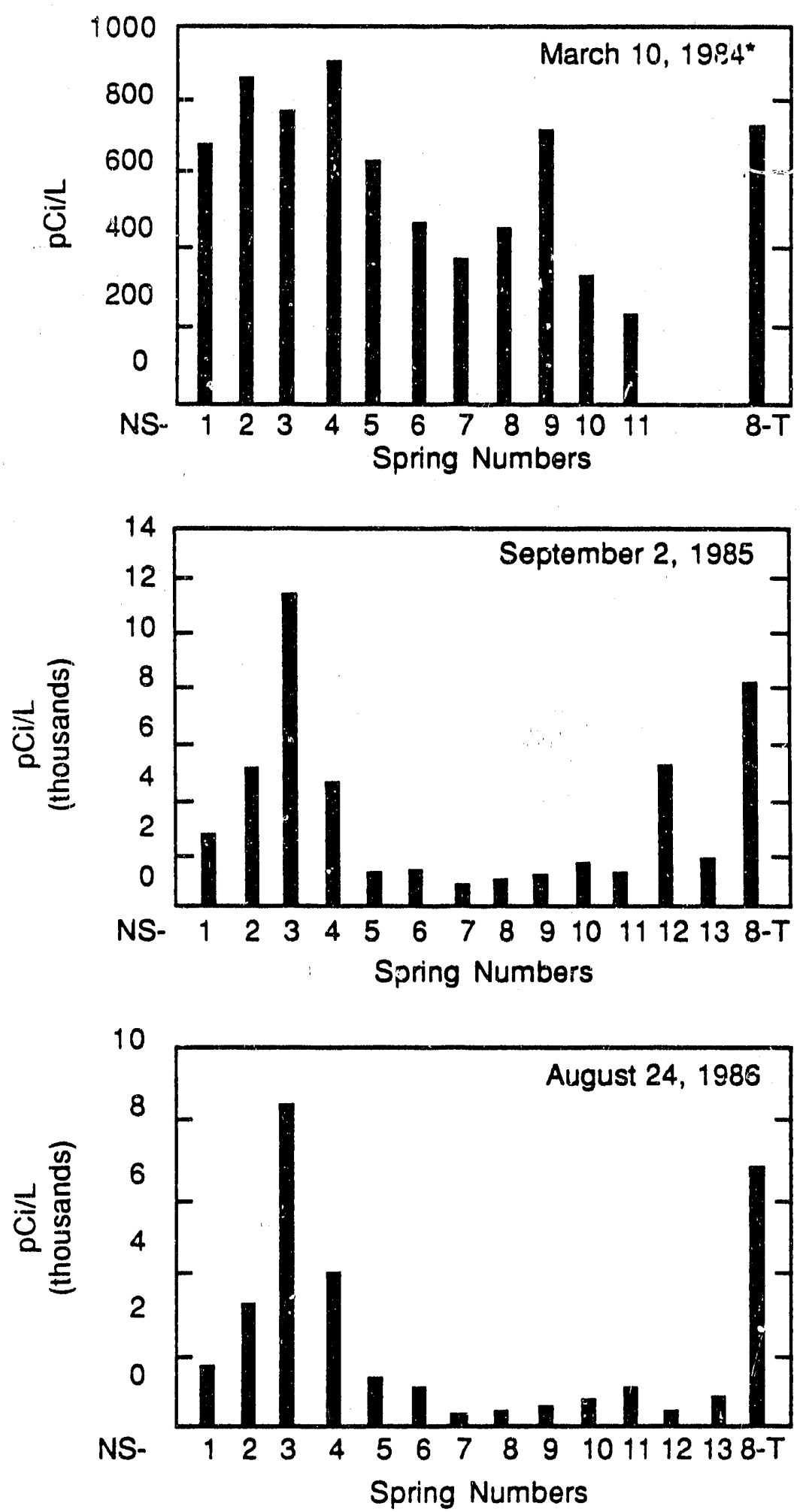

" not included in 1984 analyses.

38804-053.1M

Figure 5. Total Activity at N Springs. 


\subsection{SITE HYDROGEOLOGY}

\subsection{STRATIGRAPHY}

The Columbia River Basalt and the Ringold Formation and Hanford Site sediments underlie the reactor area. The Columbia River Basalt series forms the bedrock at a depth of $\sim 52 \mathrm{~m}(170 \mathrm{ft})$ beneath the $\mathrm{N}$ Reactor site. The basalt is generally compact, hard, and dense. The surface of the basalt reflects the structure of the flows and is only locally modified by erosion. The Ringold Formation overlies and is largely conformable to the basalt. The Ringold Formation is an extensive lacustrine and fluvial deposit of sand, silt, gravel, and clay. A sedimentary deposit of fluvial and glaciofluvial outwash sands and gravels of the Hanford Formation unconformabiy overlies the Ringold Formation. The coarse materials of this deposit are more abundant in the northwestern section of the Hanford Site, and grade into finer materials to the east and south. A generalized stratigraphic cross section is depicted in Figure 6 .

Contours of the basalt surface and the Ringold Formation surface reflect the regional structural deformation that has occurred since the Ringold Formation was deposited. The topographic highs on the basalt surface lie in the same position as the highs on the Ringold Formation surface. The lower blue clay at or near the bottom of the Ringold Formation exhibits the greatest degree of conformity with the basalt, and successively higher beds express less deformation. The Ringold Formation consists of dominantly coarse material such as sands and gravels, but locally grades into sand and coarse silt. In the eastern margin of the Hanford Site, the Ringold Formation becomes mostly silt and coarse clay (Brown 1962). Portions of the middle Ringold Formation member contain sands and gravels thoroughly cemenced with calcium carbonate.

The Hanford Site sediments lie unconformably on the Ringold Formation surface and consist of beds of unconsolidated sand, grave1, boulders, and silt that were deposited from glacial floodwaters. Exposure at the surface has caused much of this formation to be reworked into aeolian deposits, which are typically heterogeneous and poorly mixed. Discontinuous lenses of all grain sizes are common throughout the entire thickness of the formation, which can range up to $52 \mathrm{~m}$ (170 ft). In the $\mathrm{N}$ Reactor area, Hanford Site sediments are commonly sand, gravel, and boulders with some lenses of fine, well sorted materials. These sediments extend from the surface to a depth of $-18 \mathrm{~m}$ $(60 \mathrm{ft})$. The land surface in the area is hummocky, resembling "kame and kettle" topography usually associated with glacial outwash.

Geophysical logs made in 1984 to characterize the stratigraphy around the 1325-N facility generally indicate the presence of unconsolidated or semiconsoi idated sedimentary materials, including boulders, cobbles, and gravel, with some intermixed sand and silt. These logs record a thick, relatively continuous layer containing a high percentage of silt. The top of this layer is $-10.7 \mathrm{~m}$ to $13.8 \mathrm{~m}$ ( $35 \mathrm{ft}$ to $45 \mathrm{ft}$ ) below the land surface and extends down to the present water table. The thickness ranges from $-4.6 \mathrm{~m}$ to over $9 \mathrm{~m}$ ( $15 \mathrm{ft}$ to over $30 \mathrm{ft}$ ) (Prater et al. 1983). 


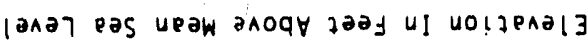

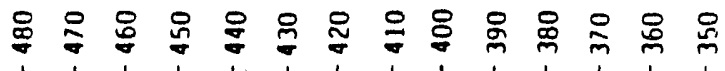

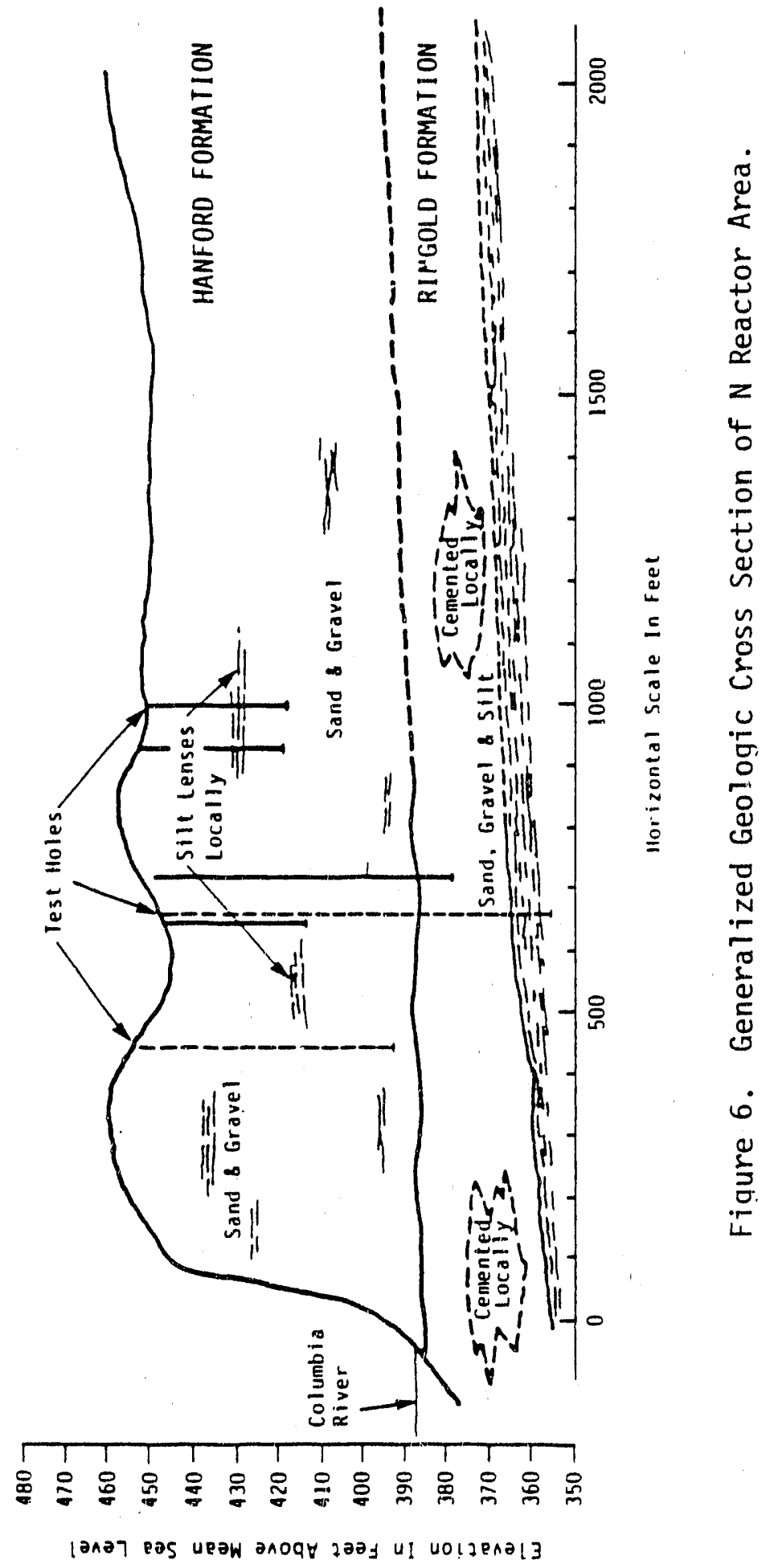


WHC - SP- 0377

Correlation of the geophysical logs around the $1325-\mathrm{N}$ facility sirows that bulk density and clay content decrease and porosity increases in the direction of the 1301-N factility and subsequently the river. These results suggest the presence of a zone of higher permeability sediments in that area: which could account for the larger spring discharge and higher radionuclide activities along a relatively localized part of the river bank (see Figure 5). In the vicinity of the 1325-N crib, the Hanford Formation is underlaid by Ringold Formation conglomerate at a contact elevation of $-125 \mathrm{~m}(410 \mathrm{ft})$ above mean sea level (Prater et a1. 1983), or $-18 \mathrm{~m}$ (60 ft) below land surface. This was approximately the elevation of the water table during the period when the geophysical logs were made and may indicate that the contact between the two formations influences groundwater movement.

\subsection{HYDROLOGY}

Groundwater head data have been collected from monitoring welis on the Hanford Site since the $1940^{\prime} \mathrm{s}$. Generalized flow directions have been well established, and the overall trend is in an easterly direction as shown on Figure 7. Comparison of 1944 data with 1986 data on the figure indicates little change in the overall direction of movement; however, large groundwater mounds resulting from post-1944 waste water disposal facilities are clearly evident in the central part of the site. The exposed basalts at Gable Butte and Gable Mountain act as low permeability features that disrupt the flow of groundwater in the surface sediments. The regional groundwater flow to the north of these structures, where the $N$ Reactor is located, is in a northerly and easterly direction toward the Columbia River. The regional lines of equipotential are aimost perpendicular to the river in the vicinity of the $N$ Reactor, indicating the general trend of regional flow is parallel with the river. Continued waste water disposal at the $N$ Reactor has locally altered the natural groundwater surface by creating a groundwater mound (not shown on Figure 7) that elevates the water table by as much as $4.5 \mathrm{~m}$ (15 ft) and causes local groundwater surface equipotentials to approximately parallel the river. The regional equipotential contours shown in Figure 7 indicate that all water entering the $\mathrm{N}$ Reactor disposal system is driven by regional groundwater flow to the north and east, so it will eventually reach the river. The temperature of the natural groundwater is $-16^{\circ} \mathrm{C}\left(60^{\circ} \mathrm{F}\right)$ and its salinity is reported to be $211 \mathrm{mg} / \mathrm{L}$ TDS (PNL 1986).

A more detailed water table map of the $N$ Reactor area is shown in Figure 8. This figure was prepared from water level data collected in April 1986 during the base period considered in this report. The equipotential contours were drawn to support the larger flow rate observed in the $N$ Springs below well $8 \mathrm{~T}$ and are consistent with the measured water levels and with the aforementioned geophysical data, which suggests a local zone of higher permeability. The flow rates of the $N$ Springs, however, have not been measured, and the river bed has not been investiçated for spring discharge.

Constant-rate pumping tests were conducted in 1984 to determine the transmissivity of the water table aquifer (Prater et al. 1983). Wells $\mathrm{N}-27, \mathrm{~N}-30$, and $\mathrm{N}-32$ (see Figure 1) were chosen because of their close proximity to the $1325-\mathrm{N}$ trench, and because drilling logs indicated the presence of a layer of cemented sediments in wells $\mathrm{N}-27$ and $\mathrm{N}-32$ and the 1 ack of such a layer in well N-30. Each well penetrates $-6 \mathrm{~m}(20 \mathrm{ft})$ below the water tabie. Tests performed in each well consisted of a $24-h$ pumping and a 
WHC-SP-0377

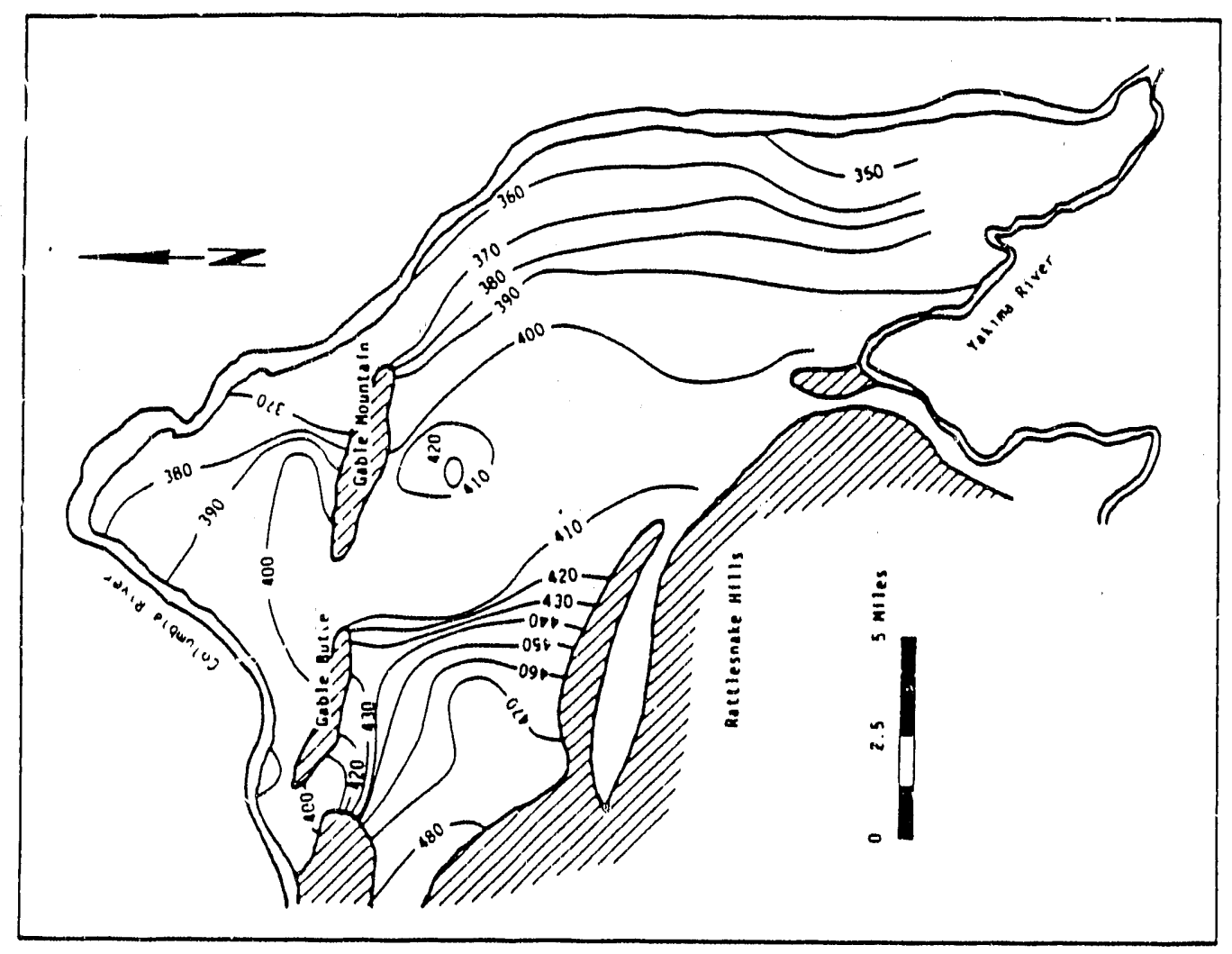

$\begin{array}{ll}\infty & \\ \infty & 1 \\ 0 & 1\end{array}$

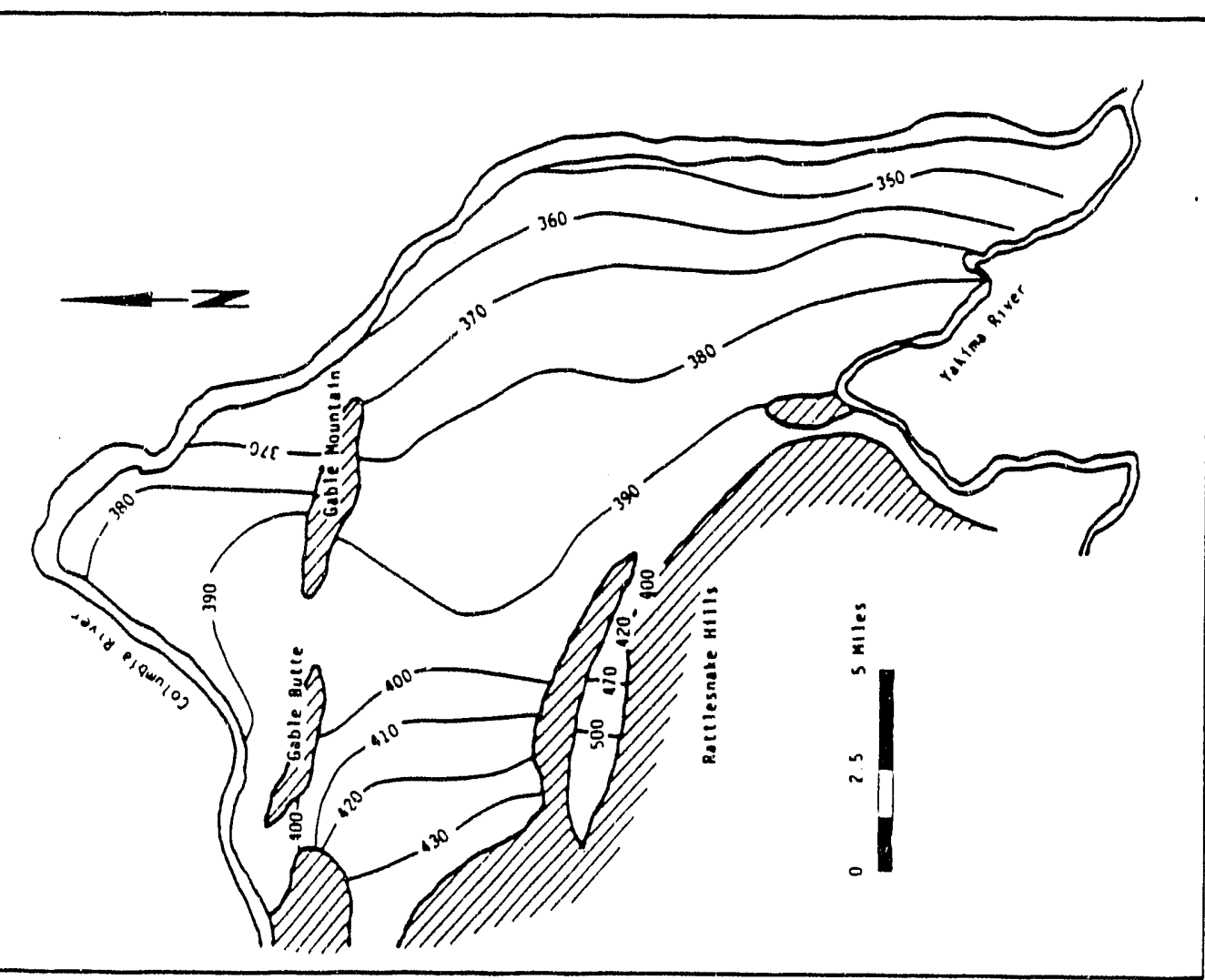



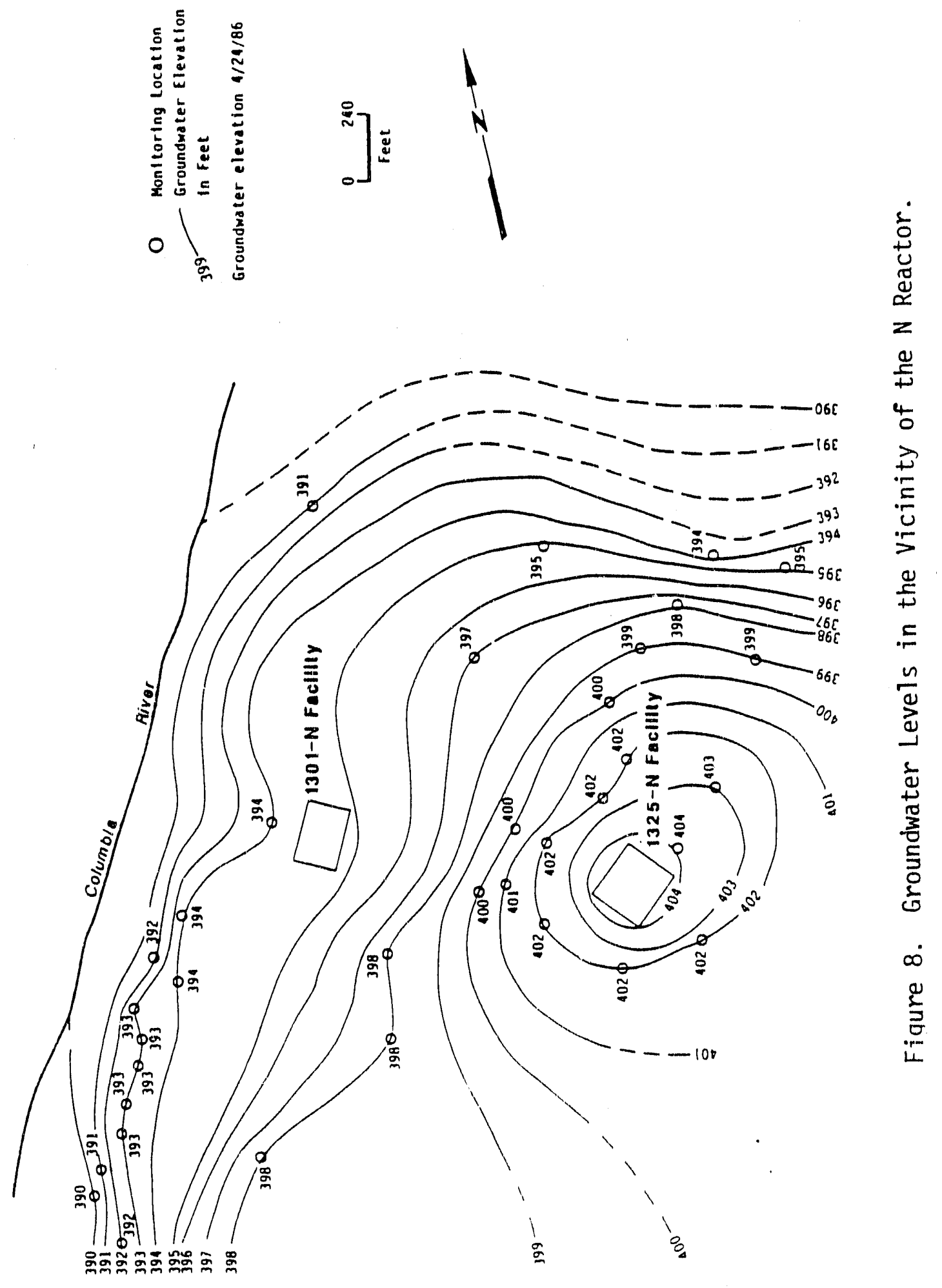
WHC-SP- 0377

24-h recovery period. Multiple observation wells were monitored for each

test. The tests in the two wells exhibiting cemented layers produced transmissivities ranging from $43,000 \mathrm{gpd} / \mathrm{ft}$ to $132,000 \mathrm{gpd} / \mathrm{ft}(535,000 \mathrm{Lpd} / \mathrm{m}$ to $1,640,000 \mathrm{Lpd} / \mathrm{m})$. The calculated transmissivity in we $11 \mathrm{~N}-30$, where no cementation was observed, ranged from $-i v 0,000 \mathrm{gpd} / \mathrm{ft}$ to $200,000 \mathrm{gpd} / \mathrm{ft}$ $(1,240,000 \mathrm{Lpd} / \mathrm{m}$ to $2,490,000 \mathrm{Lpd} / \mathrm{m})$. The results of these tests indicate the sediments have relatively high transmissivities.

\subsection{ASSESSMENT OF CURRENT RELEASE CALCULATIONS}

The present method used for estimating the annual releases of radionuclides irom the $N$ Reastor liquid waste disposal facilities to the Columbia River is based on the formula

$$
\text { Release }=0.5 Q_{F} A_{8 T}
$$

where:

$$
\begin{aligned}
Q_{F}= & \text { Total annual waste water discharged into the disposal } \\
& \text { facilities }(L / y r) \\
A_{8 T}= & \text { The average annual activity of radionuclides in the } \\
& 8 T \text { well }(\mathrm{pC} / \mathrm{L}) \text {. }
\end{aligned}
$$

This equation was originally developed for the $1301-\mathrm{N}$ facility. It has also been applied to the 1325-N facility and to short periods of simultaneous operation of both facilities.

This formula was developed based on two principal assumptions: (1) approximately half of the water discharged into the disposal facilities reaches the river with significant concentrations of radionuclides and (2) the composite sample taken at well $8 \mathrm{~T}$ provides a conservatively high estimate of the average radionuclide loading of the water reaching the river. This equation was developed to provide a simple, conservative estimating technique that could be readily applied and understood. During the 1-yr base period from October 1985 to September 1986, the average discharge to the $1325 \mathrm{-N}$ facility was $1,410 \mathrm{gal} / \mathrm{min}$, and the average activity in well $8 \mathrm{~T}$ of the six radionuclides mentioned in Section 2.0 was $6,130 \mathrm{pCi} / \mathrm{L}$. Applying the formula to these data, an estima?.ed $8.6 \mathrm{Ci}$ of radionuclides were released during the base period.

An initial evaluation suggests that this method would be expected to have overestimated actual annual releases during the routine use of either the $1301-\mathrm{N}$ or the 1325-N factlity alone, but may not have provided conservative estimates during the short periods when both facilities were being used simultaneously. The relatively symmetrical groundwater mound beneath the 1325-N facility (see Figure 8 ) indicates that approximately half the flux leaves the facility on the river side and the other half on the inland side away from the river. The waste water leaving on the river side follows -elatively short flow paths to the river, while that leaving on the inland side generally follows flowpaths to the river that are much longer. While 
this pattern holds for either the $1301-\mathrm{N}$ or the $1325 \mathrm{~N}$ facility operated independently over a long period of time, it does not hold if the factlities are operated simultaneousiy. During simultaneous operation, flux from the 1325-N facility, if substantive, would tend to drive all flux from the 1301-N facility directiy toward the river.

Hydrochemical sampling along the riverfront indicates that the highest concentration of radionuclides enters the river in a short reach closest to the disposal facilities. Farther upstream and downstream, concentrations are reduced to much lower levels. The short reach of high concentration is probably due to a local zone of higher permeabllity sediments, and to the earlier use of the 1301-N disposal facility, which appears to have directly overlaid that zone. The higher conductivity zone would be expected to consist of coarser materials that offer a smaller surface area for sorption. The higher conductivity zone would conduct more flow and its available sorptive capacity would be more quickly saturated. Further, past use of the 1301-N facility could have largely saturated the si. ative capacity along much of the higher conductivity zone before the 1325-N facility was in operation, this leaving only a small volume of soil with additional sorptive capacity for the new $1325-\mathrm{N}$ facility.

Flowpaths immediately upstream and downstream of this short reach appear to be in lower permeability materials with greater sorptive capacities, and are farther from the 1301-N facility and therefore, less affected by its operation. The considerably longer flowpaths farther upstream and downstream provide considerably more sorptive capacity, are far from the 1301-N facility, and provide more travel time for radionuclide decay. As previously mentioned, detailed sampling of $N$ Springs along the river has been conducted in 1984 , 1985 , and 1986, and the resuits were shown in Figure 5. Comparison of the 8T activities in Figure 4 with those of water from the spring samples on Figure 5 shows that activities in $8 \mathrm{~T}$ well are among the highest measured and clearly well above the averages. This field evidence supports the use of the 8T well activities as conservative estimates of the average contaminant loading of seepage into the river.

Several additional assumptions implicit in the formula and the method of monitoring must be addressed. First, by relying on samples from a single key we11 (8T we11), the computation directly addresses only a single flowpath and assumes the activity in that flowpath is conservatively representative of the contaminant loading into the river. This assumption is supported by the $N$ Springs sampling. Second, the use of annual time weighted average values of concentration and flux assumes a groundwater flow and transport system that changes slowly with time. Although the discharge and contaminant loading of the water into the crib may fluctuate rapidly, the groundwater system would be expected to considerably attenuate these fluctuations at the point of discharge into the river. As shown in Figure 4, activities measured in the $8 T$ well do not exhibit significant rapid fluctuations.

A third assumption is that the water percolating from the disposal facilities flows at or near the top of the natural groundwater and does not significantly mix with it. Several conditions may contribute to supporting this assumption: (1) vertical permeabilities may be lower than horizontal permeabilities, causing stratified groundwater flow, (2) regional upward groundwater gradients may exist causing water to flow upward from deeper aquifer systems and discharge into the river, and (3) waste water may be 
sufficiently warmer than the natural groundivater to remain buoyantly on top of the naiural groundwater. If the density of the contaminant solution is less than or the same as the groundwater, the contamillant plume will spread in a zone close to the water table (Freeze and Cherry 1979).

17though the available information for the $\mathrm{N}$ Reactor and Hanford Site generally supports the presence of the first two conditions, the data are not sufficient to quantify their effects. The buoyancy effects resulting from the temperature difference of $6^{\circ} \mathrm{C}\left(11^{\circ} \mathrm{F}\right)$ to $-17^{\circ} \mathrm{C}\left(30^{\circ} \mathrm{F}\right)$ between the waste water and the natural groundwater is expected to be the primary contributor to stratified flow. Limited hydrochemical data al so support vertical stratification of groundwaters. Field measurements from the 8-series wells of the variation of radionuclide activities with depth were obtained in January and February, 1987 (Appendix A). Those results indicated significant reductions in radionuclide activities at depths greater than $9.8 \mathrm{~m}(32 \mathrm{ft})$ below the groundwater table. However, those measurements were taken during a time when discharge to the $1325 \mathrm{~N}$ facility was approximately one half the average base period flow, so they may not be representative of conditions during the base period.

If groundwater and waste water flow are stratified, as suggested by the available data, the depth to which radionuclides migrate along the more significant, shorter flowpaths may depend primarliy upon the average volume of waste water discharged into the crib. The zone of waste water would penetrate to the greatest depths during periods of higher flow rates, and some radionuclides would be retained at those depths by sorbing on to the sediments. During periods of lower waste water discharge, the zone of waste water would be thinner, and the soils at depths formerly occupied by waste water would subsequentiy be occupied by natural groundwater which could leach the sorbed nuclides. Although the net additional transport of desorbed radionuclides by natural groundwater is normally expected to be sinall, under extreme conditions of very low flow into the cribs this phenomenon could cause an underestimation of the total releases.

A fourth assumption is that the monitoring results in well 81 are independent of river stage fluctuations. This is supported by a PNL report (Appendix B) that indicated no correlation between the radionuclide concentration in the well and the river stage. A fifth assumption is that the regional groundwater table and flow direction are relatively stable. The regional trend of groundwater flow has changed little since the $1940^{\prime} \mathrm{s}$, as Figure 7 depicts.

\subsection{ALTERNATIVE RELEASE ANALYSIS}

Two alternative, more refined approaches to estimating offsite radionuclide releases are presented in this section. The available data are sufficient to apply a simplified version of the first of these approaches to the base period. This example application provides a preliminary basis for assessing the conservatism of the release calculation presented in Section 4.0. The first approach is based on identifying flowpaths from the crib to the river, and the second approach is based on a direct computation of flux across a reference release surface. 


\subsection{FLOWPATH APPROACH}

The flowpath approach involves identifying equal flux flowpaths from the crib to the river, and assigning an average release activity to each flowpath based on field sampling of the $N$ springs along the riverbank. While the example application presented here is necessarily approxil"ate, the method can be refined, if required, through numerical modeling and ermanced field data collection. The following discussion is presented in four components:

(1) analysis of flux, (2) analysis of activicies, (3) example application, and (4) analysis of uncertainties. A comparison of this approach with the Westinghouse Hanford method is presented along with recommendations for future activities.

\subsubsection{Analysis of Flux}

The primary effect of $N$ Reactor waste water discharge on regional groundwater flow is in the vicinity of the reactor, where localized groundwater mounding presentiy occurs beneath the $1325-\mathrm{N}$ factlity. An interpretation of paths the waste water might follow away from that facility is shown in Figure 9. The flowpaths were drawn to identify areas of approximately equal waste water flux moving away from the mound based on actual field equipotential contours from the $1325-N$ facility. The method assumes the waste water forms a layer of fluid above the regional groundwater and that the equipotentials represent the surface elevation of that layer. The method also assumes that the flowlines provide an adequate indication of the direction of waste water movement, despite any local geologic heterogeneities that may be present. The flow lines indicate a concentration of flux in the area of the 8T well, which as previously mentioned, is supported by the larger spring flow observed in that area along the riverbank.

\subsubsection{Analysis of Activities}

Samples from the $8 \mathrm{~T}$ well provide a weekly record of radionuclide activities along one of the flowpaths from the $1325-\mathrm{N}$ facility to the river. The areal sampling of the springs and wells along the river shore described in Section 2.0 provides, for the date of sampling, an indication of the radionuclide activities in adjacent groundwater flow paths. If the relative distribution of these activities along the river shore is assumed to be relatively stable with time, the average annual release can be computed for each flowpath through a simple correlation with the sampling results in well 8T. The distribution of activities along the shoreline from the 1986 $N$ Springs samples is illustrated in Figure 9 (UNC 1987).

Placing emphasis on radionuclide concentrations from shallow groundwater assumes, as before, that the shallow groundwater does not significantly mix with the deeper groundwater, but that it remains at or near the water table surface. This assumption is supported by the density differences discussed in Section 4.0 between the natural groundwater and the warmer waste water emanating as springs along the river shore. 


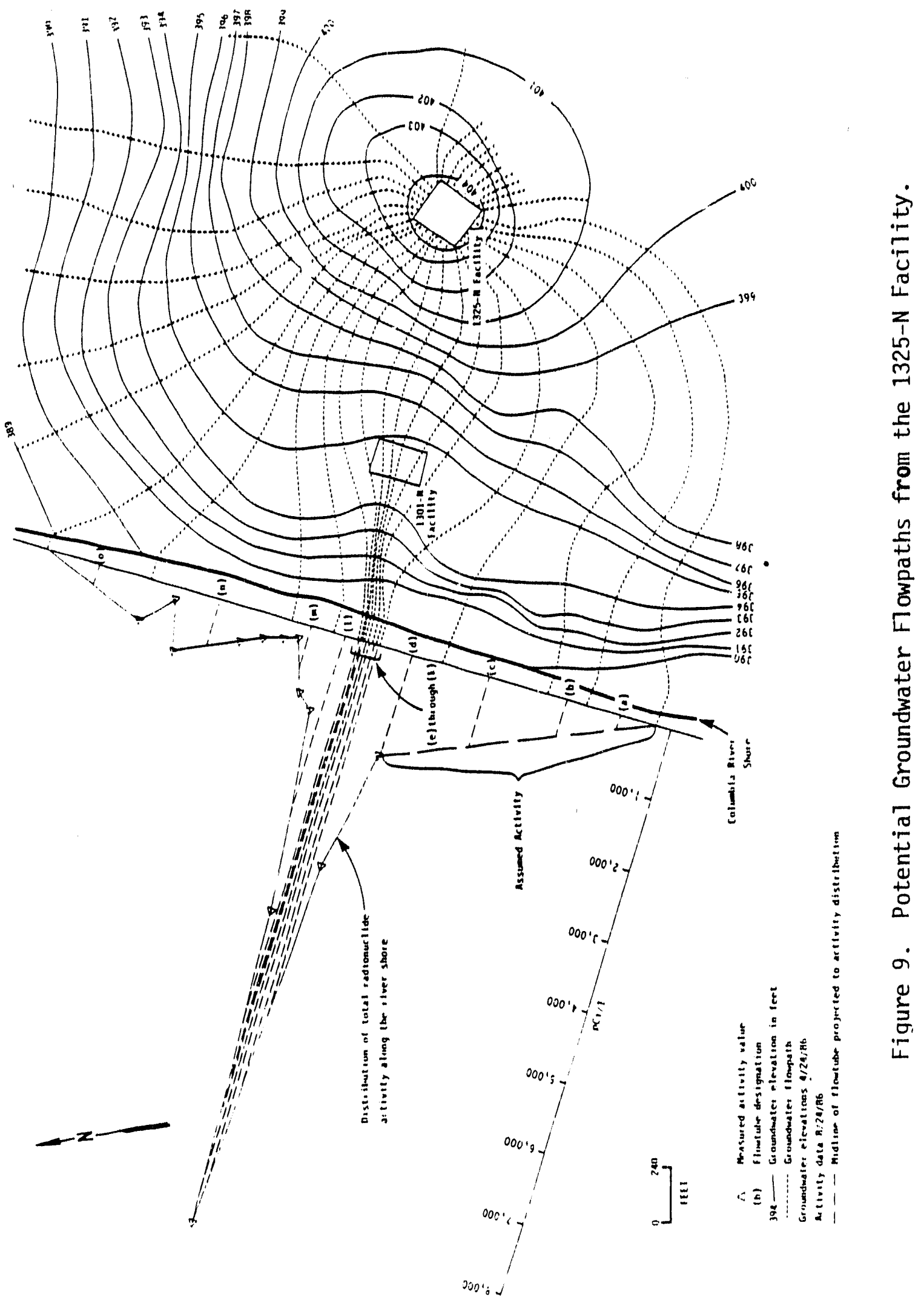


Composite samples for measurement of radionuclide concentrations are collected weekly from well 8T. Samples for measuring radionuclide concentra.. tions in the $N$ Springs have been collected annually. Activities in 8T well on the day of $N$ Springs measurement are compared with the average annual activities in that well to provide a basis for correlating the $N$ Springs measurements with the average annual radionuclide loading. The average annual release is conservatively keyed to the $N$ Springs measurements rather than the $8 T$ well measurements, because on the day of $N$ Springs measurement, the total activities in the $N$ Springs near well $8 T$ have been higher than the activities in well 8T. Samples from well 8T provide average activities for a 3 -m-thick (10-ft-thick) zone ranging from $-1.2 \mathrm{~m}$ to $4.3 \mathrm{~m}$ (4 ft to $14 \mathrm{ft}$ ) below the water table, wrile those from the $N$ springs are taken from approximately the upper foot of groundwater. The differences in activities are, therefore, consistent with the concept that the highest radionuclide concentrations are in a shallow zone at or near the water table.

\subsubsection{Example Application}

The method presented in the foregoing subsections is applied to the estimate release during the October 1985 to September 1986 base period. During that period, al1 waste water was discharged to the $1325-\mathrm{N}$ facility and all but a negligible volume of that water was percolated into the ground through tha $1325-\mathrm{N}$ crib. Groundwater flux from the crib was analyzed by dividing the outside of the crib facilitiy into 32 equal sections and assuming that the average flux out of each section is the same.

$$
Q_{F T}=\frac{Q_{T}}{n}
$$

where:

$\begin{aligned} Q_{F T} & =\text { Average flow in each flowtube (gal/min flowtube) } \\ Q_{T} & =\text { Total flow into disposal factlity (gal/min) } \\ n & =\text { Total number of flowtubes (flowtubes). }\end{aligned}$

The method assumes the flux of the system remains relatively constant over the oase period and that the three-dimensional groundwater flow system can be adequately approximated by a two-dimensional analysis. The average annual total activity of long lived radionuclides released through each flowtube $\left(A_{T}\right)$ is estimated using the relation

$$
A_{T}=\frac{\bar{A}_{8 T}}{A_{8 T}} A
$$


where:

$$
\begin{aligned}
& \AA_{8 T}=\text { Average annual total activity of well } 8 T(\mathrm{PC} 1 / \mathrm{L}) \\
& A_{8 T}=\text { Activity at weil } 8 T \text { on day of } N \text { Springs measurements }(\mathrm{PC} / \mathrm{L}) \\
& A \text { - Estimated average total activity in flowtube on day of } \\
& N \text { Springs measurements }(p C t / L) \text {. }
\end{aligned}
$$

The total activity released to the environment is then calculated by

$$
\text { Release }=\sum_{1}^{n} Q_{F T A T}
$$

During the base ferior, the average annual activity at well $8 \mathrm{~T}$ (A8T) was $6,130 \mathrm{pCi} / \mathrm{L}$, and the activity at well $8 \mathrm{~T}$ (AgT) on the day of the $\mathrm{N}$ Springs measurenient (August 24, 1986) was 6,436 pCi $1 / \mathrm{L}$. The average activity for each flowtube was taken from the shoreline activity distribution in Figure 9 and is given in column A in Table 1. These values indicate that, for this time period, the average annual activity in each flowtube was $95.2 \%$ of the $N$ Springs activity measurement on August 24, 1986. The average flow rate into the $1325-\mathrm{N}$ facility during the base period was $1,410 \mathrm{gal} / \mathrm{min}(5,340 \mathrm{~L} / \mathrm{min})$. With 32 flowtubes $(n)$, the flow in each flow tube (QFT) is $-44 \mathrm{gal} / \mathrm{min}$ $(167 \mathrm{~L} / \mathrm{min})$. Using these values and data from the 15 flowtubes where activity can be measured, the estimated base period release is $4.4 \mathrm{Ci} / \mathrm{yr}$ (see Table 1).

\subsubsection{Uncertainties in Analysis}

The approach set forth in this section provides a refinement over the current methods by considering multiple flowpaths and varying activities, yet it still can be implemented with existing information. The approach, however, necessarily relies upon a number of assumptions whose effects must be evaluated. The assumptions in the flux calculation are discussed first, followed by the assumptions in the activities.

5.1.4.1 Uncertainties in Flux Calculation. The fundamental assumption in the flux calculation is that the discharge from the crib can be reasonably subdivided into flowtubes of equal flux in a two-dimensional approximation of the real three-dimenstonal system. This assumption is supported by the buoyancy of the warmer waste water as discussed in Section 4.0, which suggesis that in the vicinity of the $N$ Reactor, the water flows in a layer on top of the natural groundwater. The assumption is also supported by the approximately circular symmetry of equipotentials around the disposal factilty, which indicates that water is flowing away from the facility with a generaily uniform flux in all directions. If any significant heterogeneities in hydraulic properties were present in the immediate vicinity of the $1325-\mathrm{N}$ crib, they would be indicated by irregular equipotentials. If warranted, identification of equal-flux flowtubes can be refined through numerical modeling. 
Table 1. Flowtube Activities.

\begin{tabular}{|c|c|c|c|}
\hline Flowtube & $\begin{array}{c}\text { Column } A \\
\text { estimated average } \\
\text { flowtube activity } \\
\text { on } 8 / 24 / 86 \\
(p C i / L)\end{array}$ & $\begin{array}{c}\text { Column B } \\
\text { percent of } \\
\text { total activity }\end{array}$ & $\begin{array}{c}\text { Column } C \\
\text { estimated average } \\
\text { annual flowtube } \\
\text { activitya } \\
(\mathrm{pC}+\mathrm{L})\end{array}$ \\
\hline \multirow[t]{2}{*}{$\begin{array}{l}A \\
B \\
C \\
D \\
E \\
F \\
G \\
H \\
I \\
J \\
K \\
L \\
M \\
N \\
D\end{array}$} & $\begin{array}{r}220 \\
550 \\
1,100 \\
1,450 \\
5,400 \\
6,350 \\
7,750 \\
7,850 \\
6,650 \\
6,150 \\
5,300 \\
2,600 \\
650 \\
680 \\
300\end{array}$ & $\begin{array}{r}0.0 \\
1.0 \\
2.0 \\
3.0 \\
10.0 \\
12.0 \\
15.0 \\
15.0 \\
13.0 \\
12.0 \\
10.0 \\
5.0 \\
1.0 \\
1.0 \\
0.0\end{array}$ & $\begin{array}{r}209 \\
524 \\
1,047 \\
1,380 \\
5,141 \\
6,045 \\
7,378 \\
7,473 \\
6,331 \\
5,855 \\
5,046 \\
2,475 \\
619 \\
647 \\
286\end{array}$ \\
\hline & 53,000 & & 50,456 \\
\hline
\end{tabular}

aFor period October 1985 through September 1986.

$$
\begin{aligned}
\text { Column } C & =\frac{\bar{A}_{8 T}}{A_{8 T}} \times \text { Column } A \\
& =0.952 \times \text { column } A
\end{aligned}
$$

(15 flowtubes) $(44 \mathrm{gal} / \mathrm{min})=660$ flowtube $-\mathrm{gal} / \mathrm{min}$

(660 flowtube-gal/min)(3.785 L/ga1) (1,440 min/day) $(365 \mathrm{~d} / \mathrm{yr})(50,456 \mathrm{pCi} / \mathrm{L})$

$=4.4 \mathrm{Ci} / \mathrm{yr}$ 
The flux calculation assumes that the groundwater flow system is essentially stable throughout the year. While this assumption is thought to be valid for the base period studied, it could be invalidated, for example, by periodic heavy use of the 1325-N trench or significant long-term flow reductions. The method can be adapted to treat significant short-term transients, but additional field monitoring data and possibly the use of numerical models may be required. The method may not conservatively estimate release during periods of significantly reduced waste water flow, because sorbed radionuclides would be leached and cransported during such periods by the natural groundwater.

Uncertainty also exists in the shape of the groundwater equipotentials between the $1325-\mathrm{N} \mathrm{crib}$ and the river. More accurately identifying the degree of flowtube concentration that results in the larger springs along the shoreline near well 8T is of particular interest. The flowlines drawn in Figure 9 were purposely concentrated near that well to provide a more conservative release estimate. Water level information from additional monitoring wells now being installed between the crib and the river should permit a more accurate identification of the equipotentials.

5.1.4.2 Uncertainties in Activity Calculations. The activity calculations also assume relatively stable conditions throughout the period of analysis, such that the distribution of radionuclide releases along the shoreline remains predictable between measurements. The method can be adapted to more variable conditions by increasing the frequency of activity measurements in the $N$ Springs as allowed by periods of low river flow.

As discussed in Section 4.0, the accuracy of the shallow groundwater samples in representing average flowtube activities during the base period is expected to be good for the shorter flowpaths between the crib and the river. However, the conservatism of this approach relies on the assumption that the shallow samples are little affected by mixing with the natural groundwater. A zone of mixing will be present along the interface between the waste water and groundwater. The thickness of that zone will increase with distance away from the mound. If the zone of mixing extends to the water table and significantly reduces radionuclide concentrations in the shallow $N$ Springs or we11 8T samples, then the flux from the crib should be supplemented by a component of natural groundwater flux when computing releases to the river. Mixing could be a more significant factor in the longer, wider flowpaths because the layer of waste water flow will be less thick and more time will be available for cooling and mixing to occur. However, more time and greater soil volumes are also available for radionuclide decay and sorption in those longer flowpaths. The $N$ Springs sampling along the river shore indicates that releases from these longer flowpaths are currently not significant.

\subsection{FLUX APPROACH}

The flux approach involves identifying the flux across a reference release surface on which the distribution of radionuclides is known. The flux is based on a simple linear application of Darcy's law and the radionuclide activities that are taken from sampling along the river shore. An example application of this method could not be prepared because the hydraulic conductivities and distributions of activities with debth are not sufficientiy 
quantified along the multiple flowpaths that would have to be considered. Although this approach has the advantage of simplicity and does not require assumptions regarding vertical mixing, its application will require obtaining additional field measurements.

\subsubsection{Flux Analysis}

The flux across the reference release surface would be determined using the equation

$$
Q_{F}=K i A
$$

where:

$Q_{F}=$ Flux across the jncremental portion of the reference surface under consideration $\left(\mathrm{m}^{3} / \mathrm{s}\right)$

$K=$ Average hydraulic conductivity of the sediments along the relevant flowpaths $(\mathrm{m} / \mathrm{s})$

$i=$ Hydraulic gradient in the vicinity of the release surface $(\mathrm{m} / \mathrm{m})$

$A=$ Area of the release surface $\left(\mathrm{m}^{2}\right)$.

The hydraulic conductivity would be determined from pump tests conducted in wells near the release surface. The hydraulic gradient would be determined from water level measurements in the $N$ Reactor monitoring wells, and the area of the release surface would be based on the depth and lateral extent of significant radionuclide activity. The release surface is a vertical plane at or near the river shore, upon which the depth and lateral extent of radionuclide activities and the changes that occur over time can be measured or estimated.

The total activity released to the environment would be calculated by

$$
\text { Retease }=\sum_{1}^{n} Q_{F} A_{F}
$$

where:

$$
\begin{aligned}
& A_{F}= \text { Depth weighted average radionuclide activity across the inçremental } \\
& \text { portion of the reference surface under consideration }\left(\mathrm{C} / \mathrm{m}^{3}\right) \\
& \mathbf{n}=\text { Total number of increments along the surface (dimensionless). }
\end{aligned}
$$

\subsubsection{Activities Analysis}

Radionuclide activities would be determined along the release surface using essentially the same methods as those for the flowpath approach, except additional information would be required on variations with depth on different 
flowpaths. Viriations with depth would be monitored at several locations near the river shore and extrapolated to unmonitored locations, based upon local geologic and hydrologic conditions.

\subsubsection{Uncertainties in Analysis}

Uncertainties in the flux approach would stem primarily from the extent to which the controlling parameters of hydraulic conductivity, gradient, and radionuclide activity are representative of the portion of the release surface being considered. The gradient is already reasonably well known, and relatively few additional field tests are expected to be required to obtain sufficient information on the two remaining parameters.

\subsection{RECOMMENDATIONS}

\subsection{RELEASE CALCULATIONS}

A comparison of the current release calculation method with the results of the first alternative method presented in Section 5.0 indicates that the current method is probably conservative in estimating radionuclide release to the Columbia River. Total release for the 12-mo base period of October 1985 to September 1986 was estimated by the current method to be $8.6 \mathrm{Ci}$. The al ternative flow path method estimates a release of $4.4 \mathrm{Ci}$ for the same period. This alternative method provides release estimates for all significant flowpaths and is considered to be more accurate than the current method. Although a number of simplifying assumptions have necessarily been introduced into the example calculation presented in this report, additional accuracy can be obtained, if required, through more frequent field data collection and application of numerical models. However, an even greater level of accuracy would be expected from application of the alternative flux method of analysis a) so presented in Section 5.0. The flux method would not require extensive additional numerical modeling, but would require some additional field data. The present uncertainties in both the current method and the flowpath method are considered sufficient to justify collecting additional data.

The simplicity of the current method for determining release concentrations allows calculations to be made quickly and conservatively, and this method can continue to be applied as long as it can be demonstrated to provide conservative results. It is recommended that the conservativeness of the current method be checked on a periodic basis by comparison with the results of the more detailed alternative approaches presented in this report.

\subsection{ACTIONS TO REDUCE UNCERTAINTIES}

Recommendations are provided in this section to reduce present uncertainties in estimating radionuclide releases. Most recommendations include simple field tests and extensions of current activities. 


\subsubsection{Pump Testing}

Additional information on hydraulic conductivities are needed near the river shore to support trial application of the alternative flux method described in Section 5.2. Three locations are recommended for testing: (1) upstream from well $8 \mathrm{~T}$ in the vicinity of Hell $\mathrm{N}-19$, (2) in the vicinity of wel1 8T, and (3) downstream from well $8 \mathrm{~T}$ and inland from $\mathrm{N}$ Springs 10.

\subsubsection{Radionuclide Monitoring Expansion}

Additional multilevel well installations are recommended to provide more detailed information on radionuclide distribution and temperature with depth near the Columbia River. This information will help support release calculations by any of the methods discussed in this report. Two locations are recommended: (1) upstream from well $8 \mathrm{~T}$ in the vicinity of well $\mathrm{N}-19$, and (2) downstream from wel1 8T and inland from $N$ Springs 10 . These are the same general locations as recommended for pump tests, and if properly staged, the multilevel wells could be used as monitoring wells to provide information on vertical as well as horizontal hydraulic conductivities.

\subsubsection{Radionuclide Sampling Frequency}

The alternative release calculation methods presented in this report are based on the relationship of $N$ Springs concentrations to well $8 T$ concentrations on a specific day of the sampling year. More frequent sampling of the $N$ Springs, the multilevel well installations, and other established monitoring wells would reduce uncertainties from fluctuations and strengthen the relationship between the springs and well $8 \mathrm{~T}$.

\subsubsection{Groundwater Monitoring Frequency}

A11 release calculation methods assume that the groundwater table and hence the directions of the waste water flowpaths are relatively stable over the period of analysis. Monthly monitoring of groundwater elevations would help to verify this assumption and provide insight into geologic and hydrologic processes that influence water table levels and radionuclide transport.

\subsubsection{N Springs Monitoring Network Expansion}

Current $N$ Springs monitoring locations are limited to visible seeps along a $1.5-\mathrm{mi}$ stretch of river at the $\mathrm{N}$ Reactor. Investigation and sampling of any springs that occur upstream and downstream of this reach should continue to be performed to help validate contaminant release calculations. In addition, installation and sampling of additional shallow wells are recommended at locations outside this reach where there are no springs to verify the present assumption of negligible releases at those locations. If geologic conditions determined from subsequent investigations indicate the potential presence of higher conductivity zones that could permit significant waste water releases 
to bypass the monitoring system, seepage meters should be installed in the Columbia River to monitor underwater discharge. Water temperatures should be measured with each sampling.

\subsubsection{Water Leve1 Monitoring Network Expansion}

Increasing the number of developed monitoring wells will help to assess water level trends and verify flow path directions. Geophysical testing of new wells will help identify the presence or lack of a higher conductivity path within the sediments. Emphas is should be given to improved monitoring between the 1325-N facility and the river. We understand that additional wells are currently being installed in that area.

\subsubsection{Documentation}

Complete documentation should be prepared describing the details of all future monitoring, testing, well installation, and operational activities associated with waste water disposal. Studies made to evaluate the system should be supported with comprehensive presentations of the data, the analyses, and the assumitions made.

\subsubsection{Numerical Analysis}

Additional numerical analyses are not recommended until they can be better supported by additional field data.

\subsection{GROUND DISPOSAL OPTIONS}

\subsubsection{Structural Options}

Structural options that could divert waste water away from the apparent higher condictivity flowpath and around the previously used $1301-\mathrm{N}$ facility include builaing a new disposal facility far from the river and constructing a subsurface barrier wall. The first option of building a new disposal facility would be desirable; however, it is our understanding that this has been considered and is not feasible. A subsurface low permeability barrier that would force groundwater to flow around the 1301-N facility would be expected to impede the transport of radionuclides now present in the soil beneath this former disposal facility, and would increase the path length of waste water now flowing from the 1325-N facility. The effectiveness of such a barrier should be evaluated in more detail before committing to this option. We recommend that a relatively low priority be given to structural options in view of the benefits that can potentially be obtained at relatively low cost: from the operation options discussed below. 


\subsubsection{Operational Options}

Rerouting waste water now discharged into the $1325-\mathrm{N}$ crib to the furthermost end of the 1325 $\mathrm{N}$ trench would provide several advantages. Waste water would then migrate through soil that has had little or no previous disposal history, which would therefore be expected to have enhanced sorptive properties. Discharging waste water to this end of the trench will also change the configuration of flow from the facility to the river, with less waste water passing beneath the 1301-N facility, and less being concentrated in the apparent higher conductivity flowpith at the 8T we11. Adoption of this option may affect the validity of the present method of calculating releases, however, because well $8 \mathrm{~T}$ would no 1 onger lie on the most direct flowpath to the river.

Reduction of the volume of waste water to the facility would reduce the overall flux in the system. Total flow to the $1325 \mathrm{~N}$ facility will be reduced to $-650 \mathrm{gal} / \mathrm{min}(426 \mathrm{~L} / \mathrm{min})$ for $\mathrm{N}$ Reactor operation. If the radionuclide concentrations are unaffected, any reduction in flow would tend to reduce the net radionuclide release. The reduction in release may, however, not be proportional to the reduction in flow because of mobilization of sorbed radionuclides by natural groundwater. Avoiding large fluctuation in waste water flow would enhance the accuracy of the release calculations.

Along with a reduction in flow, it has been proposed that a reduction of temperature and TDS will also occur. As discussed in Section 4.0, a decrease in temperature may not be desirable under the present monitoring system due to decreased buoyancy of waste water and increased mixing with natural groundwater. A decrease in TDS would increase buoyancy and have the opposite effect. Extreme decreases in TDS could however have a deleterious effect by increasing the ability of the waste water to mobilize presently sorbed radionuclides. It would be most desirable to discharge very low TDS water near the outer end of the $1325-\mathrm{N}$ trench.

\subsection{REFERENCES}

Brown, D. J., 1962, Geology Underlying Hanford Reactor Areas, HW-69571, General Electric Company, Richland, Washington:

Freeze, R. A. and J. A. Cherry, 1979, Groundwater, Prentice-Hall Inc., Englewood Cliffs, New Jersey, pp. 396-397.

PNL, 1986, Environmental Monitoring at Hanford for 1986, PNL-6120, Pacific Northwest Laboratory, Richland, Washington.

Prater, L. S., J. T. Riger, E. S. Clein, E. J. Jensen, T. L. Liikala, and K. R. Oster, 1983, Groundwater Surveillance at the Hanford Site for CY 1983, PNL-5041, Pacific Northwest Laboratory, Richland, Washington.

UNC, 1987, Characterization of Radionuclide Concentrations of the $\mathrm{N}$-Springs along the Columbia River Shoreline, UNI-4217, UNC Nuclear Industries, Richiand, Washington. 
WHC-SP-0377

\section{APPENDIX A}

N SPRINGS VERTICAL PROFILE 


\section{UกC กUELEAR INDUSTR!ES}

In a continuing effort to assess the accuracy of the $N$-Springs radionuclide release reporting (currently based on the $N-B T$ composite sampler) a vertical profile sampling regime was conducted between January 12 and February 18, 1987. The study involved sampling of several ground water wells along the $\mathrm{N}$-Area shoreline near the $N-8 T$ well, but from varying depths in the water table (see Figure 1).

The $N-8 T$ sampling well collects samples from a specific stratum in the ground water table. While not scientifically incorrect methodology, this does not necessarily represent radionuclide concentration conditions from the entire vertical profile of the water table. To determine if dissimilar conditions exist, water samples from various depths in the water table were collected and analyzed.

Four of the wells sampled (N-8-P, Q, R, S) are one and one-half inch diameter piezometer wells with varying depths into the water table. These wells have perforation zones (10 foot in length) which are significantly deeper that the N-8T well perforation zone. These increased depths allow for radionuclide concentration comparisons over an extended profile of groundwater strata.

Another nine samples were taken from yet a different ground water we11, N-46. This is an 8" diameter well which is screened along its entire affected area (25' depth) in the water table. Samples were obtained from this well from the uppermost region in the water table extending downward in one foot increments to approximately eight feet into the water table. This eight foot stratum represents virtually the same ground water layer that the $\mathrm{N}-8 \mathrm{~T}$ samples. However, examining the ground water in smal1 increments provides the ability to determine if there is any stratification within this region of nuclide concentrations compared to those observed by the N-8T well.

In the case of the $N-8-P, Q, R$, \& $S$ wells, as depth into the ground water increased, radionuclide concentrations decreased respectively, and in the deepest wells, the nuclide concentrations were at less than detectable levals (see Table 1). 
L. P. Dlediker

Page 2

February 27, 1987

With the exception of I-131, the one foot incremental sampling in well N-46 compared very closely wt th the radionuclide concentrations reported by the N-8T well (see Table 2). Though generally higher than the N-8T concentrations, the I-131 concentrations seen in the $\mathrm{N}-46$ we 11 are significantly lower than the historical average $(2,000$ to $3,000 \mathrm{pCi} / \mathrm{L})$ reported before the new 1325-N factilty was placed into service in September, 1985. The DOE Derived Concentration Guide (DCG) is $3,000 \mathrm{pCt} / \mathrm{L}$ for $1-131$. One possible explanation for the increased I-131 concentrations in the upper strata of ground water is the tendency for this nuclide to volatilize raptdly. With travel times from the $1325-\mathrm{N}$ crib being approximately 90 days for $1-131$, it is predictable that its concentrations would be highest in the upper region of the water table by the time it appears at the $\mathrm{N}$-Springs.

Based on this vertical profting of the N-Springs water table, the N-8T well is sampling from the stratum of ground water containing the highest radionuclide concentrations being released to the river.

CJP/tik

Attachments

CC: JJ Dorian
KA Gano
WJ Klover
KM Probasco
DJ Rokkan
VR Richards
DA Wiggins
CJP:File/Ib


FIIILIRE I

VERTICAL PRDFILE SAMFLING WELLS

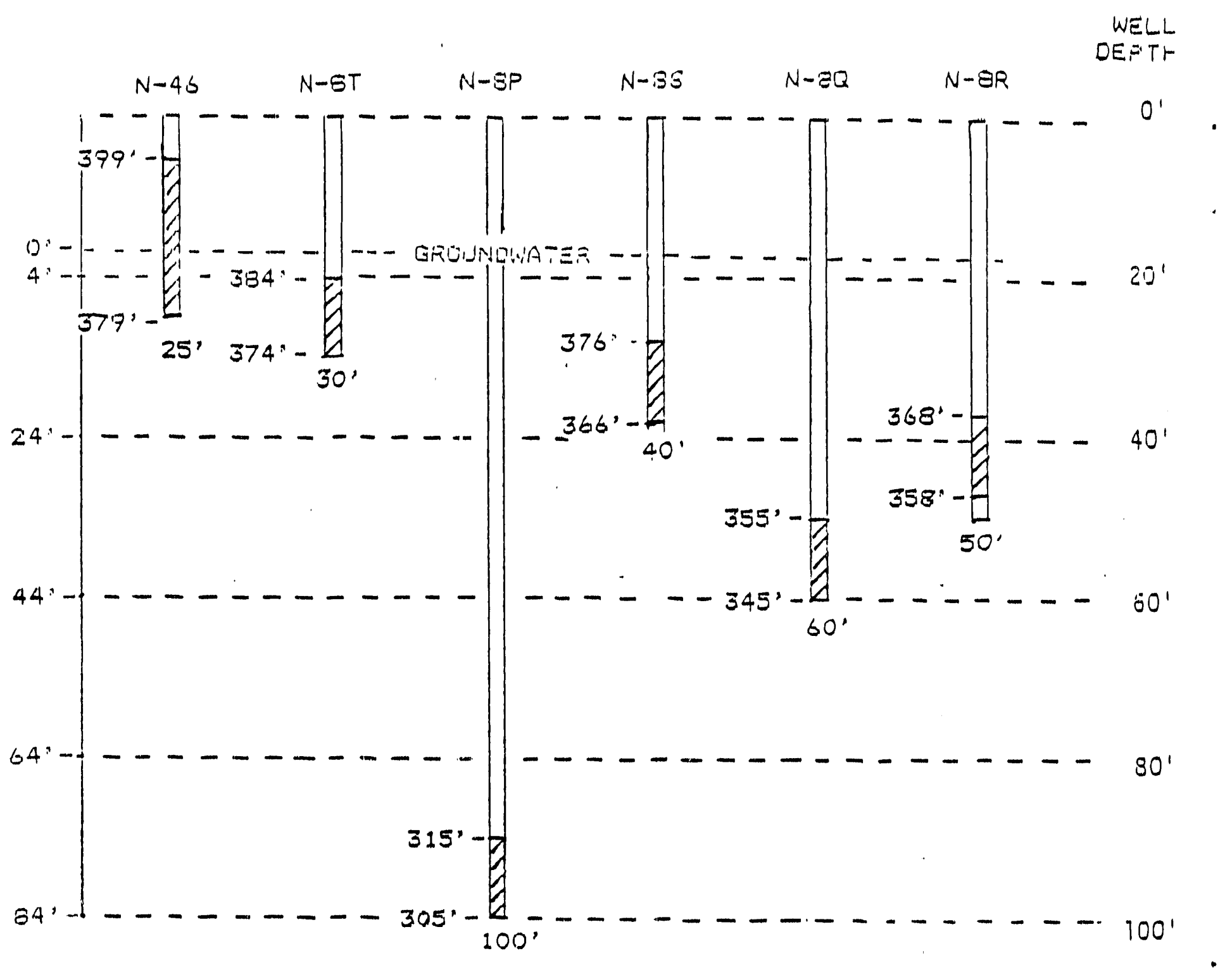

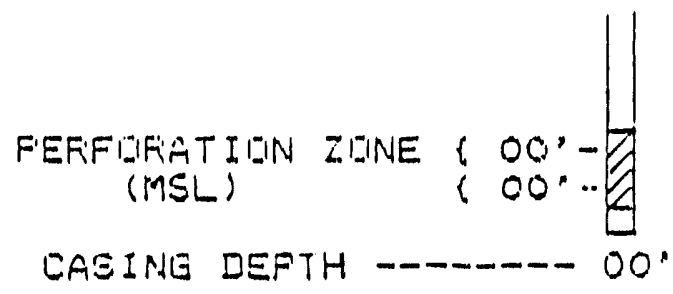


WHC-SP-0377

TAPLE 1

RAUIONUCLIDE CONCENTRATIONS IN WELLS N-8-P,Q,R,S

$(\mathrm{pC}+\mathrm{L})$

\begin{tabular}{|c|c|c|c|c|c|c|}
\hline $\begin{array}{l}\text { (depth filto } \\
\text { water table ....) }\end{array}$ & $\begin{array}{c}N-8 P \\
\left(74^{\prime}-84^{\prime}\right) \\
\end{array}$ & $\begin{array}{c}N-80 \\
\left(34^{\prime}-44^{\prime}\right) \\
\end{array}$ & $\begin{array}{c}\quad N-8 R \\
\left(22^{\prime}-32^{\prime}\right) \\
\end{array}$ & $\begin{array}{c}N-8 S \\
\left(12^{\prime}-22^{\prime}\right) \\
\end{array}$ & $\begin{array}{l}* \\
4 \\
4\end{array}$ & $\begin{array}{l}\frac{8 T}{a v g} C Y^{\prime} 86 \\
\left.14^{\prime}\right)\end{array}$ \\
\hline radtorucltde & & & & & & \\
\hline $00-60$ & 6 & 10 & 75 & 78 & 100 & 94 \\
\hline Ru-103 & $<6$ & $<8$ & 11 & 20 & 3.4 & 37 \\
\hline$R u-106$ & $<46$ & $<54$ & 95 & 87 & 81 & 89 \\
\hline$S b-125$ & $<19$ & $<22$ & $<24$ & 66 & 120 & 120 \\
\hline $1-131$ & $<9$ & $<11$ & $<10$ & $<10$ & 22 & 23 \\
\hline
\end{tabular}

*N-8T compost te sample taken from $2 / 11-2 / 19 / 87$ 
WHC-SP-0377

TABLE 2

RADIONUCLIDE CONCENTRATIONS IN N-46 WELL.

$$
(p C i / L)
$$

\begin{tabular}{|c|c|c|c|c|c|c|c|c|c|c|c|}
\hline \multirow[b]{2}{*}{$\begin{array}{l}\text { Depth into } \\
\text { water table .... }\end{array}$} & \multirow[b]{2}{*}{211} & \multirow[b]{2}{*}{11} & \multirow[b]{2}{*}{$\underline{2^{\prime}}$} & \multirow[b]{2}{*}{$3^{\prime}$} & \multirow[b]{2}{*}{$4^{\prime}$} & \multirow[b]{2}{*}{$5^{\prime}$} & \multirow[b]{2}{*}{$6^{\prime}$} & \multirow[b]{2}{*}{$7^{\prime}$} & \multirow[b]{2}{*}{$8^{\prime}$} & \multicolumn{2}{|c|}{$N-8 T$} \\
\hline & & & & & & & & & & $*$ & $\begin{array}{l}\text { avg } \\
c y^{\prime} 86\end{array}$ \\
\hline \multicolumn{12}{|l|}{ radtonuclide } \\
\hline Co-60 & 97 & 100 & 100 & 99 & 96 & 100 & 110 & 97 & 97 & 100 & 94 \\
\hline$R u-103$ & 56 & 61 & 62 & 59 & 60 & 59 & 56 & 58 & 41 & 59 & 37 \\
\hline$R u-106$ & 100 & 120 & 110 & 110 & 150 & 93 & 140 & 140 & 79 & 92 & 89 \\
\hline$S b-125$ & 97 & 100 & 110 & 120 & 110 & 98 & 110 & 120 & 120 & 120 & 120 \\
\hline$I-131$ & 190 & 190 & 200 & 190 & 180 & 140 & 120 & 130 & 87 & 58 & 23 \\
\hline
\end{tabular}

*N-8T composite sample taken from $1 / 7-1 / 14 / 87$ 
WHC - SP- 0377

APPENDIX B

100-N CRIB STUDY, PHASE III 


\section{ERRATA \\ APPENDIX B}

\section{0-N Crib Study, Phase III}

Because several tables and figures appear in Appendix $B$ that were not referenced in the text, this sheet lists changes to Appendix $B$ that clarify its ambiguity. For each change listed, there is an accompanying number in parentheses in the right-hand margin of Appendix B.

1. For "can be seen in Figures 1 through 10" read "can be seen in Figures 1 through 11."

2. For "Table 1 records the disposal volumes and identifies" read "Tables 1 through 6 record the disposal volumes and identify."

3. For "Figures 1 through 3" read "Figures 1 through 4."

4. For "The three figures" read "Figures 1 through 4."

5. For "shown in Figures 4 through 6" read "shown in Figures 5 through 7."

6. For "Appendix Table 4" read "Table 4"

7. For "Figure 7 shows" read "Figure 8 shows."

8. For "Figures 8 through 10 show" read "Figures 9 through 11."

9. For "were performed" read "were performed (Figures 2 and 3)." 
Date June 9, 1982

CT Kincaid

To Larry Diediker

DA Zimmerman

To Lar

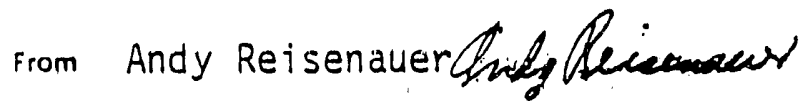

AER/File

Subject 100-N Crib Study, Phase III

The Phase III Crib Study work proposed to UNC March 24, 1982 has been completed and two separate letter reports are attached.

Du-ing the initial study it became clear that additional daily I-13I data were available from fuel failure incidents records (contained in UNI-1460). On your verbal approval that funding was available for additional work, we began an analysis which we believe could add significant understanding to the I-131 travel times. When funding bocame uncertain, efforts on this increased scope of work were terminated. At this time a cost overrun of $\$ 1 K$ does appear on our books. We feel the work should be continued and completed. Coupled with the results of column studies currently underway, the analyses of fuel failure incidents could yield an independent calculation of travel time for the iodine. It may be possible to determine if retardation or dilution is the primary cause of the I-131 reduction seen at the river bank springs.

Estimated Budget to Complete Work

\begin{tabular}{|c|c|}
\hline $\begin{array}{l}\text { Labor } \\
\text { Computer Time }\end{array}$ & $\begin{array}{r}\$ J .1 K \\
.4 K \\
\end{array}$ \\
\hline Subtotal & $\$ 3.5 \mathrm{~K}$ \\
\hline Cost Overrun & 1.0 \\
\hline . & \\
\hline
\end{tabular}

We recognize that we continued beyond the scope of the original work; however, we were lead to believe that funding was available and that the analysis was of the greatest urgency. Funding in the amount of $\$ 4.5 \mathrm{~K}$ is requested to complete this work effort and issue a letter report. If the new work is not approved and funded, it is requested that a supplement of $\$ 1 K$ be approved to cover the present overrun.

AER:del

Attachments 
Phase III, Tasks 1, 2 and 3 of 1301-N Crib Study - Model Existing Conditions and Examine Two Disposal Options for a New Crib

Introduction

A study was made of the ground-water flow characteristics beneath the 100 $N$ area of the Hanford Reservation. The objective of the study was to determine the effects of constructing and operating a replacement to the 1301-N waste disposal crib located about 800-1000 fit east of the existing crib. The objective included determining the effects of the new crib on the existing tile drain field, determining the effects of river stage on the travei times and distances to the river, and determining the effects of two waste disposal plans.

The Variable Thickness Transient (VTT) model was used to simulate the ground-water system response to various river stages and disposal plans. The model and the data used to calibrate it have been developed and collected over an extensive period of time as part of the Haniord Waste Management and. Environmental Monitoring Proyram. Specific disposal volume, disposal site coordinates, and operating plans were provided by UNC. The VTT model is installed and run on a POP 11/70 computer. Results displayed in this letter report were generated on various peripheral devices of the PDP 11/70 system.

The VTT model uses finite difference techniques to simulate horizontal, two-dimensional, saturated ground-water flow. The model can be used in either a steady state or transient mode, and it can handie confined or unconfined aquifer systems. The 100-N area has been modeled previously using ine VTT model; the same basic model was set up for this analysis.

\section{Study Procedure}

The resolution necessary for a study of the $1301-N$ trench requires that the $V T T$ model be run for two spatial resolution scales. The initial simulation for each river stage involved a VTT model of the entire Hanford site. Inputs to the mode? included the Hanford site data base, the river flow condition(s), and the trench and pond infiltration quanitites for the site. A steady-state simulation was made for the Hanford site and subsequently used to set boundary conditions for the study area immediately surrounding the 
100-N Area. This study area, with its significantly greater spatial resolution, was then run for the existing $1301-\mathrm{N}$ crib and two disposal options for the new crib. The VTT model of $100-\mathrm{N}$ was run nine times to simulate three different flow conditions and different crib disposal options. The three river flows were a low flow of 35,000 cfs chosen as the lowest flow that would be released from Priest Rapids Dam; a flow of 100,000 cfs chosen as an average flow; and a flow of 350,000 cfs chosen as the highest sustained flow that would likely occur in this reach. The calculated potentials for each of the runs were plotted and streamlines were drawn from each of the disposal areas. The results of the runs can be seen in Figures 1 through 10 and in Appendix A. Appendix $A$ contains Tables $A-1$ through A-9 which show the travel time and distances along each streamline started from three separate lines near the cribs. Table 1 records the disposal voiumes and identifies the model nodes at which these sources are appiied to the ground-water system.

\section{Discussion}

Figures 1 through 3 show the current disposal plan with the river boundaries held at low, average, and high flows. These represent a base condition for comparison of the new crib disposal options. The three figures show little change in the flow paths with the different river levels. The flow paths from the "back" (inland side) of the existing mound appear to be most changed, but given the length of travel and the time of travel, they are of little concern in this study. The streamlines were started from three different locations around the disposal sites. The large number of lines and their corresponding travel times were developed to show travel directions and times from every side of the disposal area. The shortest travel times from the crib to the river for the average river discharge are 0.03 yeurs or about 11 days. The 11 day travel time is influenced by the distance between the crib and the river in the model, which is several hundred feet further than the measured distance on site due to spatial resolution. This travel time is reasonable given the assumption of the Hanford site data. Given the flow directions generated by the model, the calculated travel times and the potential surface representation, it appears that the model represents the existing conditions. 
The first disposal option using the new crib would split the waste streams between the new and old crib according to their origin. The second option would dispose of all waste streams to the new crib. Under the first option the primary loop and bleed stream which contains essentially all of the I-131 would be disposed to the new crib, and other streams such as the spill cooler water and the 100-iN fuel storage basin overflow would be disposed to the old $130 \mathrm{~L}-\mathrm{N}$ crib and trench. Thus, the water disposed at the old crib would act to divert streamlines from the new crib into longer paths. For the purposes of studying this option the present disposal volume was split equally between the new and old cribs.

The water surface potential maps for the three different river levels of this option are shown in Figures 4 through 6 . The mound that appeared in the initial or base condition has shifted to the location of the new crib and is due to the point discharge of one half of the existing flow into the new crib. The potential maps appear to be essentially the same with only minor variations in the directions the various equipotentials. The streamlines for the low flow condition show somewhat more divergence and longer travel times. Appendix Tabie 4 shows that for average flow the travel times for the shortesi streamlines are about 127 days. The increased travel time is due in part to the increased distance separating the river from the new ground-water mound. The streamline origins have been changed from the base case so that the 1 ines would show the travel times and directions from the new crib. In this analysis there is no apparent decrease in gradient or change in the flow pattern created by the old crib. An additional computer run was made on the area of the two cribs to attempt to define more clearly the flow paths. Figure 7 shows an expanded view of the region around two disposal sites. The flactened portion of the potential surface shows the effects of the split disposal. Streamiines from the new crib site are diverted around the 1301-N crib and travel times are correspondingly longer.

The second disposai option placed all of the flow into the new crib. Figures 8 through 10 show the potential surfaces for this option. The travel times for the streamlines are listed in Table 4. For average river flow the shortest travel time was 69 days. It is readily apparent that the travel times and distances for the second disposal option are shorter than those for 
the spitt disposal option. The decreased travel times are the result of the direct route to the river (undiverted by disposal to the existing crib), and by the increased head caused by disposal in a smaller area.

An additional concern with the disposal of large volumes of wastes at 100-N is the possibility of inundating the sanitary tile drain field by raising the water table. Table 6 lists the water table elevations calculated by the model under the sanitary tile drain field for each of the disposal plans and each of the river conditions. The bottom of the tile field is at elevation $439 \mathrm{ft} \mathrm{ms} 1$. The highest ground-water table beneath the site would be created by disposing all of the flow into the old crib during high river flow. The elevation of the tile field is higher than any potential water surface that would occur with the proposed disposal options.

\section{Conclusions}

The model appears to be a good representation of the ground-water conditions beneath the 100 $\mathrm{N}$ reactor area. Neither of the two disposal options modeled would affect the tile drain field. The travel times from the new crib to the river in all cases are significantly longer than the present disposal practices, 0.19 years vs 0.03 years.

Using the average river flow (100,000 cfs) as the point of comparison for the two options, the shortest travel time to the river $(0.19$ years) occurred when all wastes went to the new srib. Travel time from the same release iocations increased to 0.35 years when the wastes were split between the old and new cribs. Under this option ground-water flow originatirig at the new crib was forced to move around the waste being disposed to the old crib. The same relative comparisons hold true for the other river flows used in the modeling. 
WHC -SP-0377

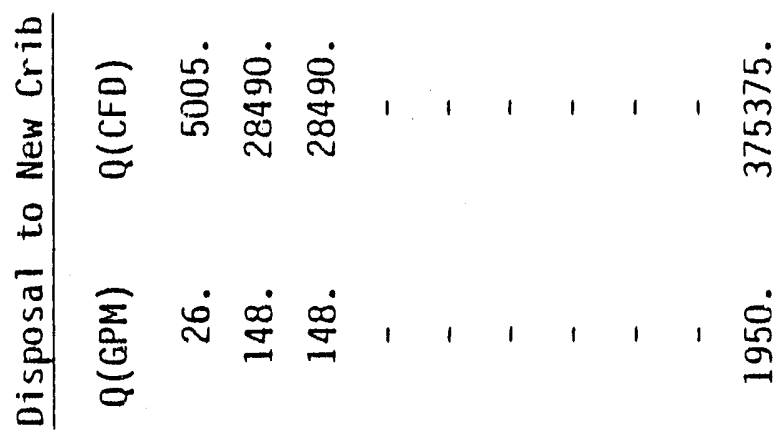

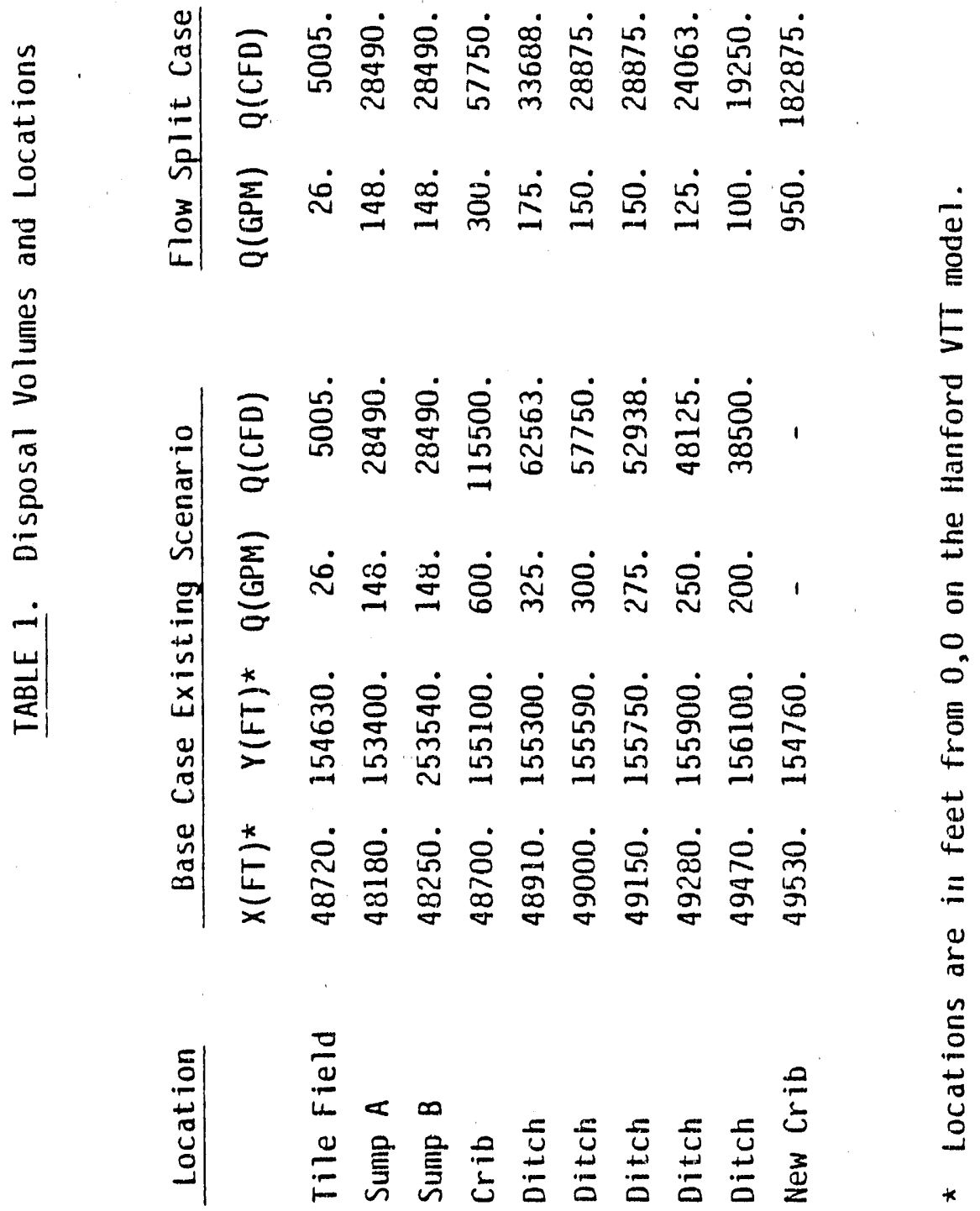




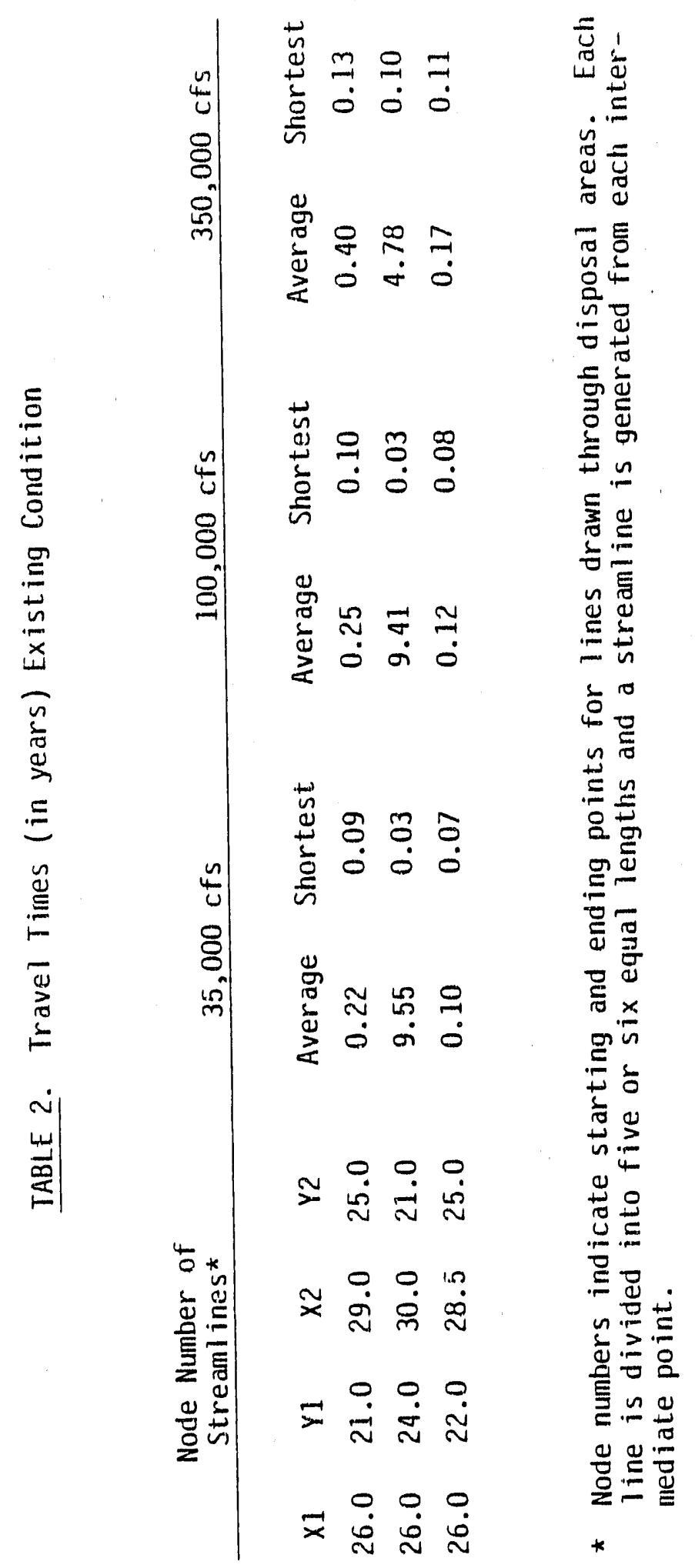


WHC - SP-0377

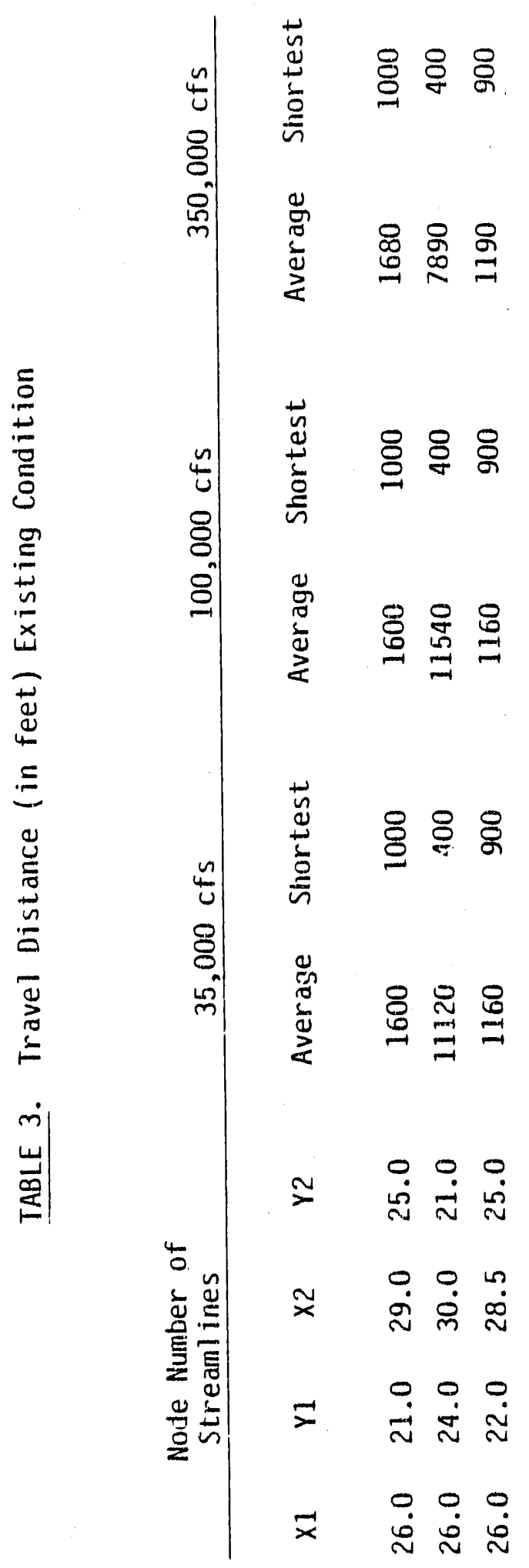




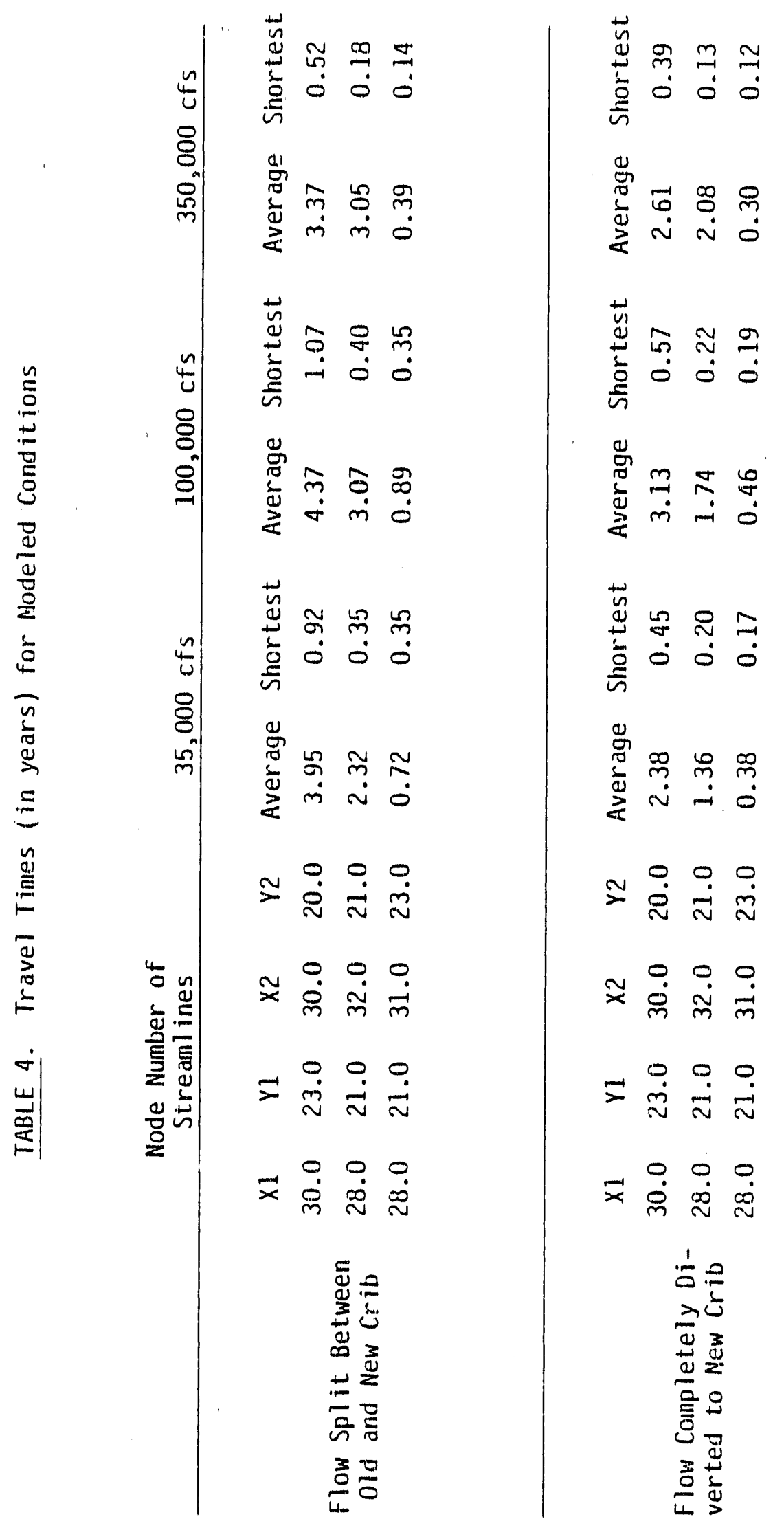




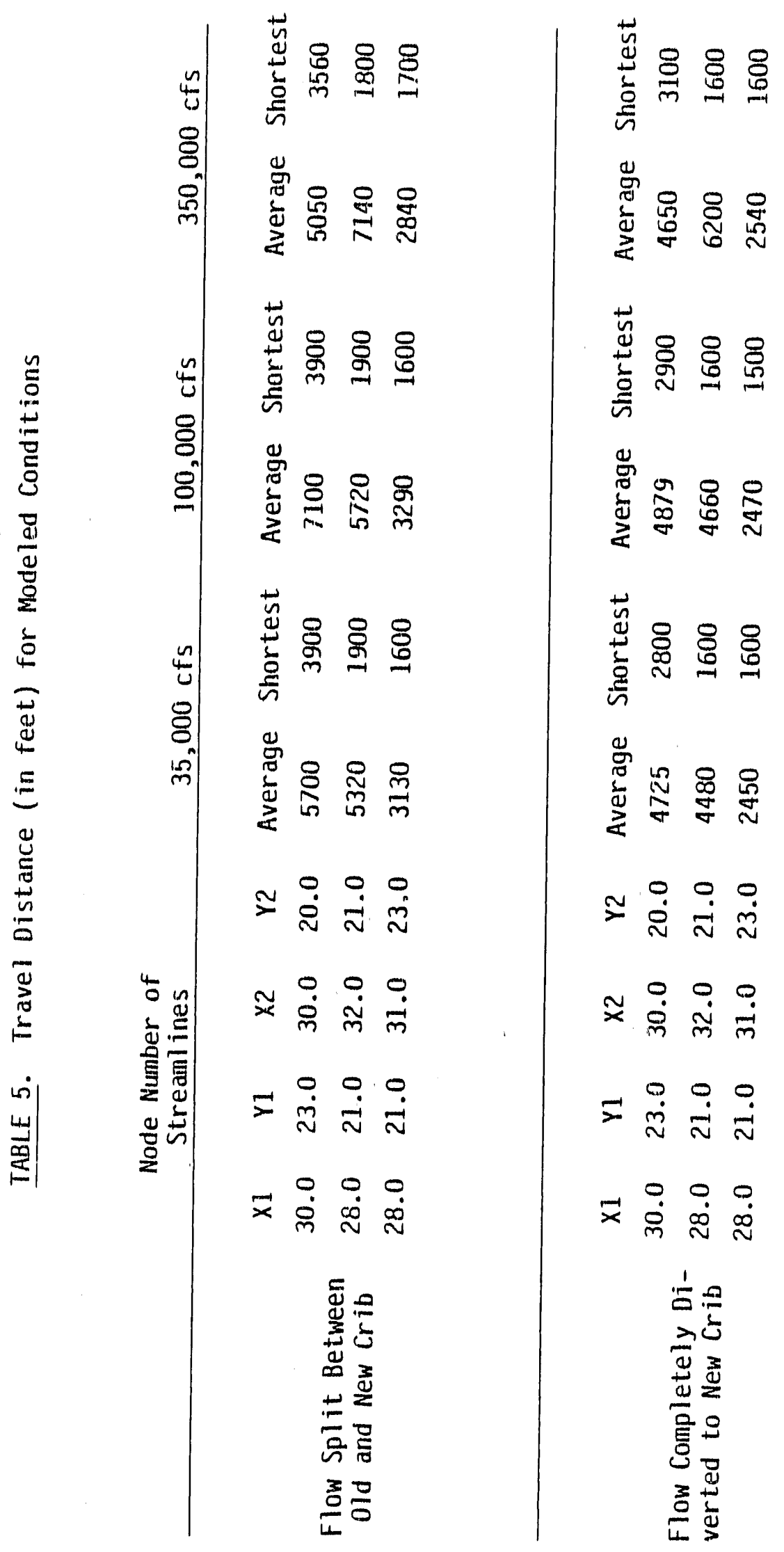


TABLE 6. Predicted Potentials (in feet msl) at Tile Field

Thle fleld location on small area -. node 21,27

Elevation of tile fleld 439 ms 1

$35,000 \mathrm{cfs} \quad 100,000 \mathrm{cfs} \quad 350,000 \mathrm{cfs}$

Extsting Condition $\quad 390.7 \quad 394.1 \quad 404.2$

$\begin{array}{llll}\text { Split Flow } & 390.6 & 393.9 & 401.9\end{array}$

Flow Diverted To

New Crib

390.4

393.8

40.1 .8 
WHC - SP- 0377

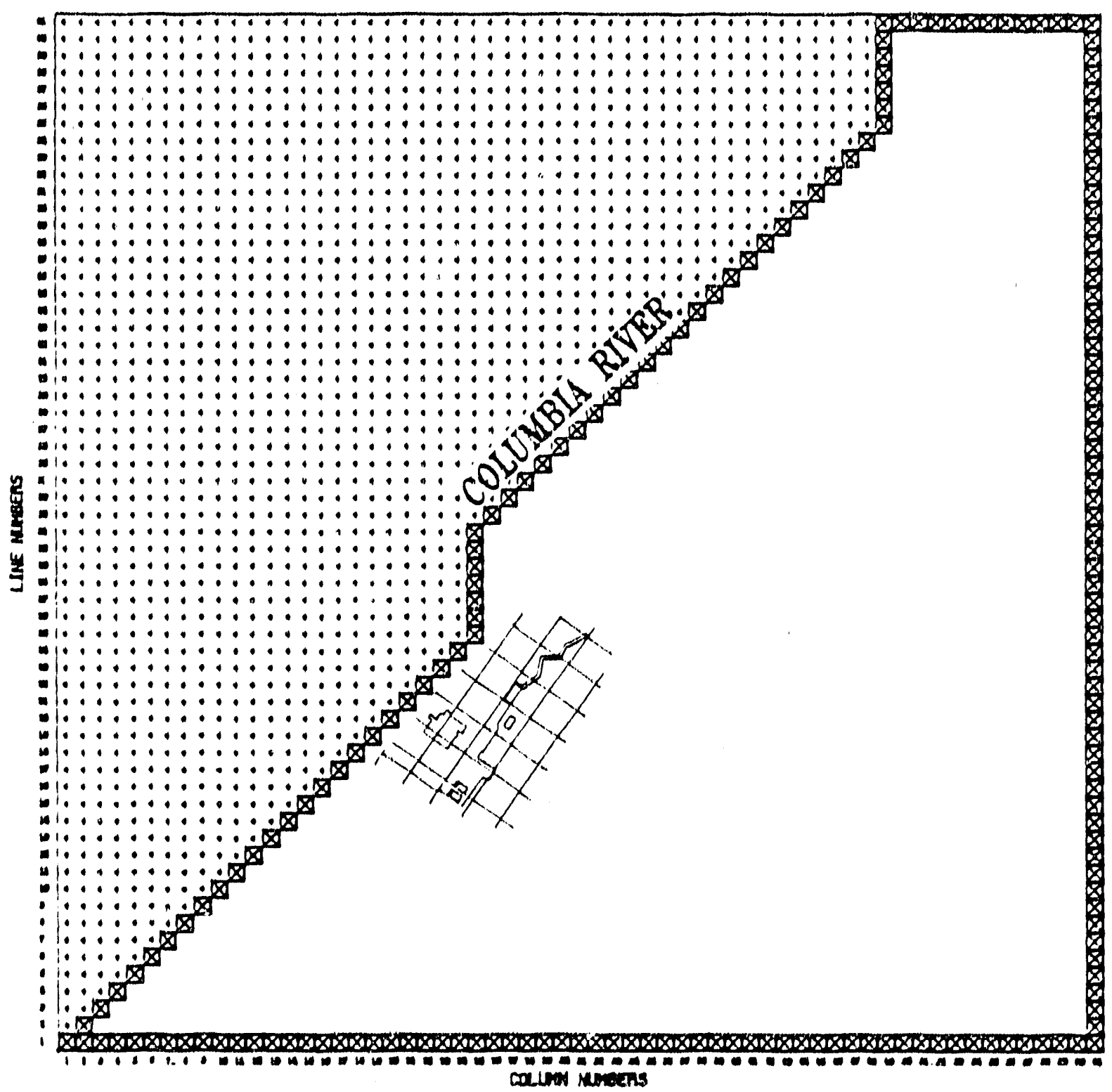

FIGURE 1. Location Map, Reference for all Figures Except 8. 
WHC-SP-0377

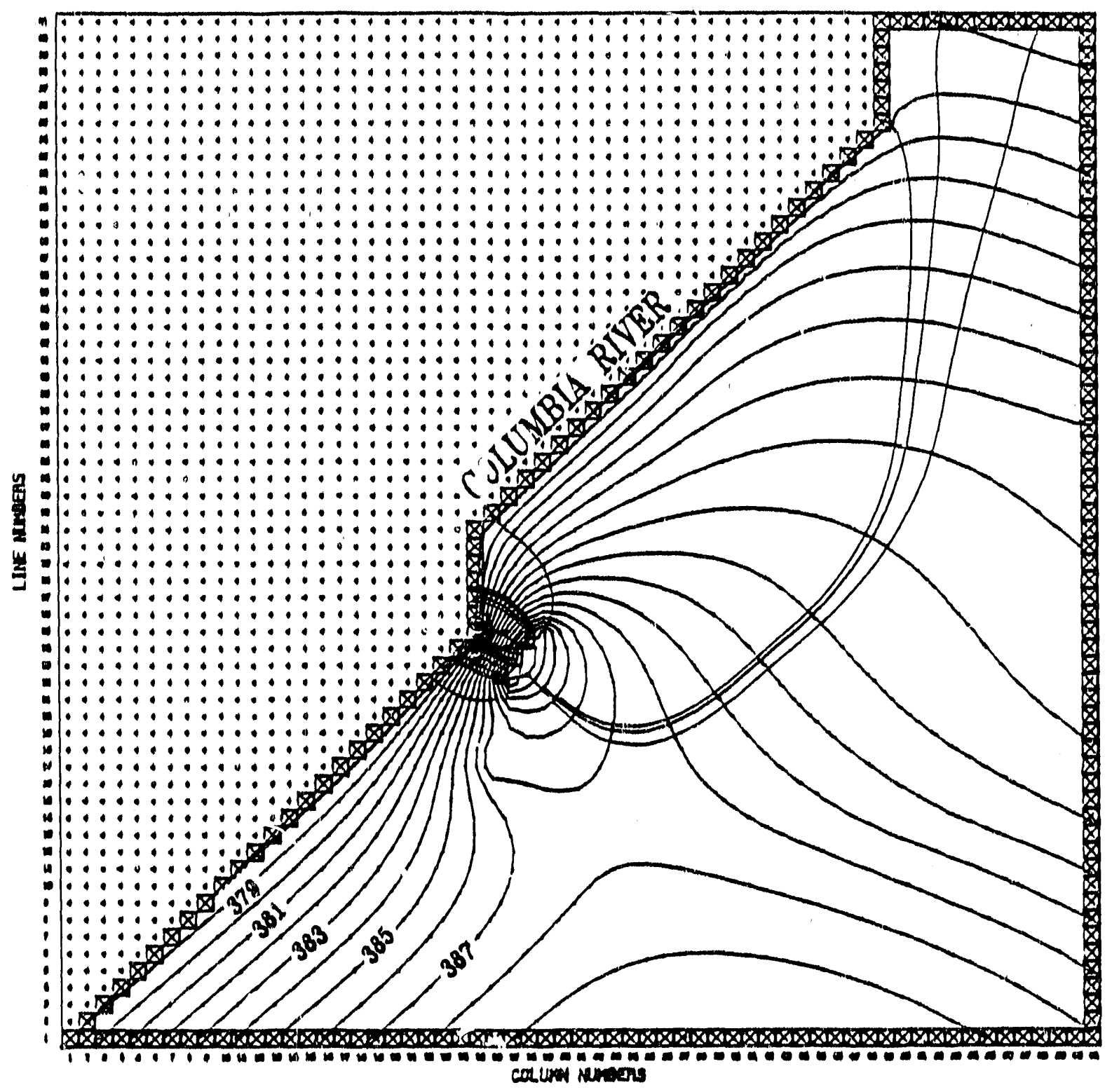

FIGURE $\therefore$ Ground Water Potential Surface with River Flow at 35,000 cis -Existing Conditions 


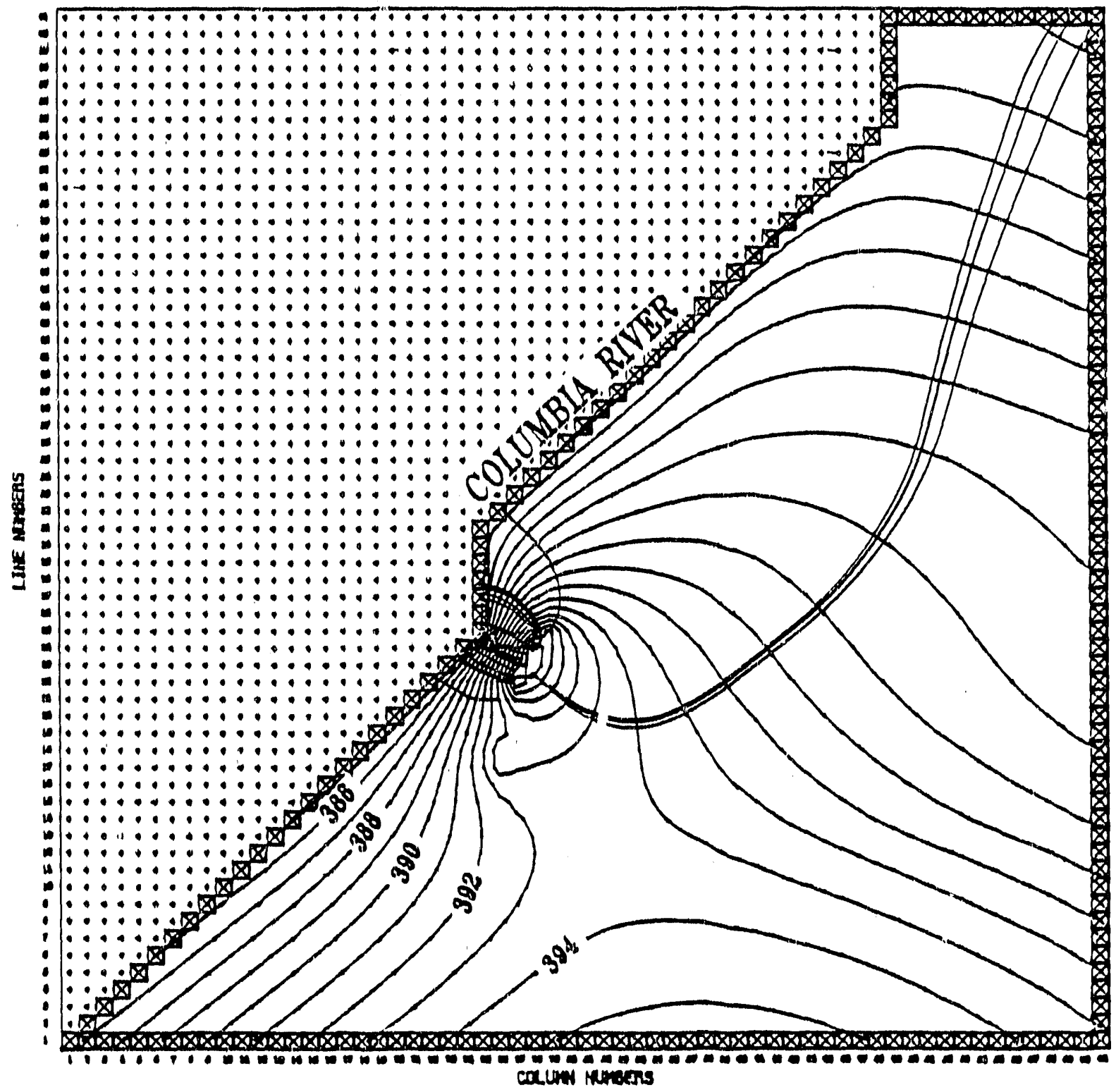

FIGURE 3. Ground Water Potential Surface with River Flow at 100,000 cis - - Existina Conditions 
WHC - SP - 0377

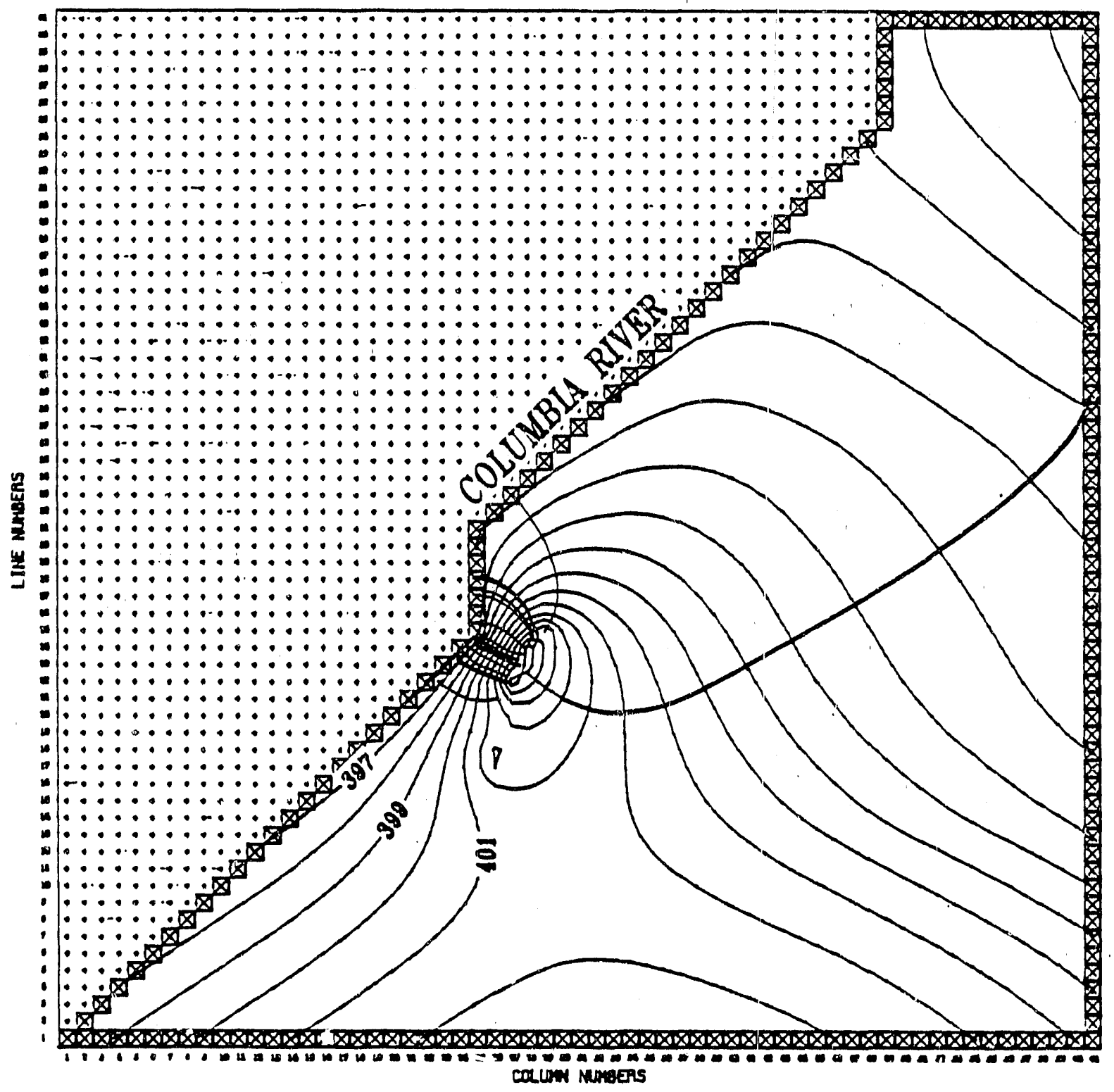

FIGURE 4. Ground Water Potential Surface with River Flow at 350,000 cfs -- Existing Conditions 
WHC - SP- 0377

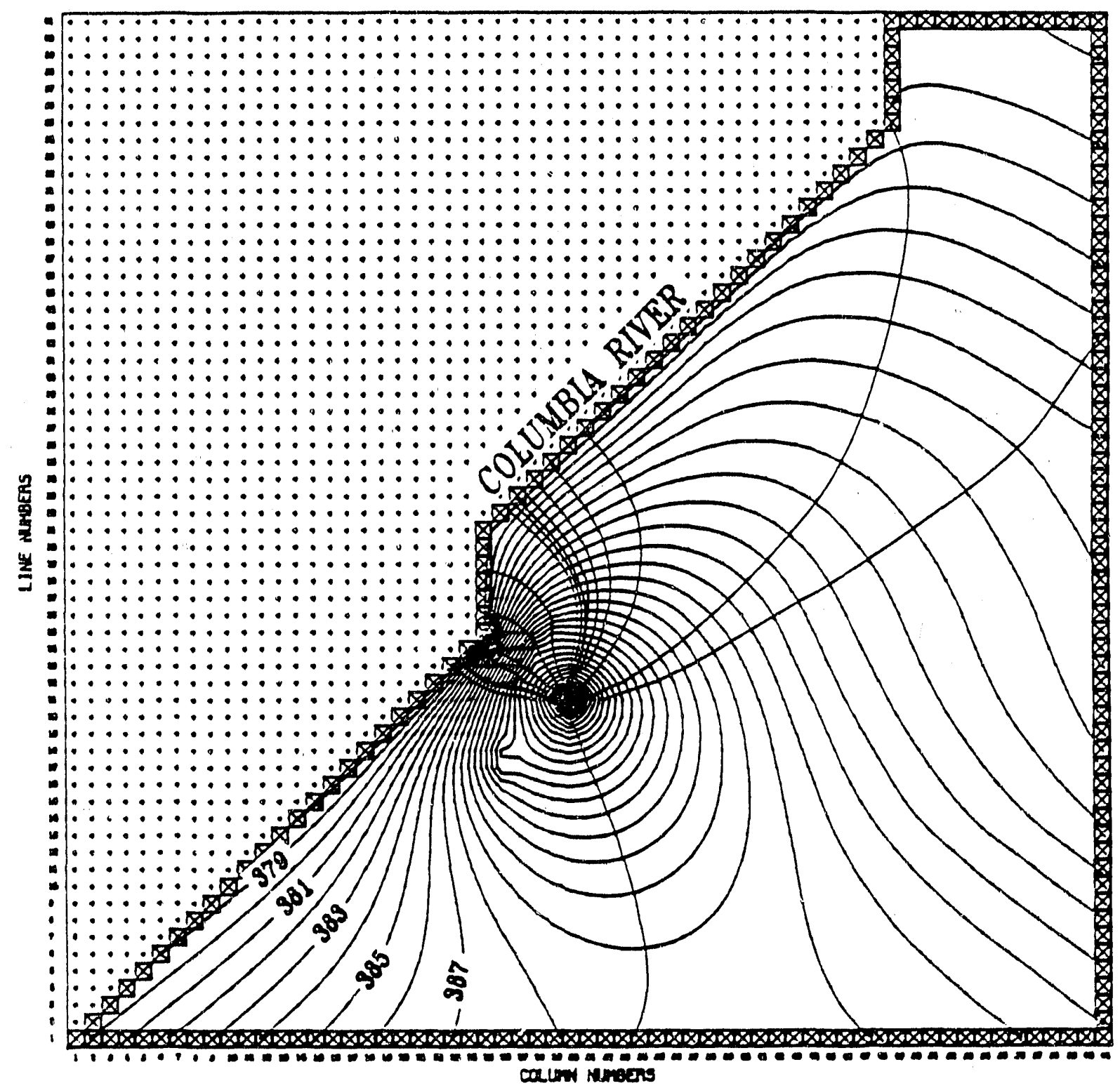

FIGURE 5. Ground Water Potential Surface with River Flow at 35,000 cfs - Crib Flows Split 


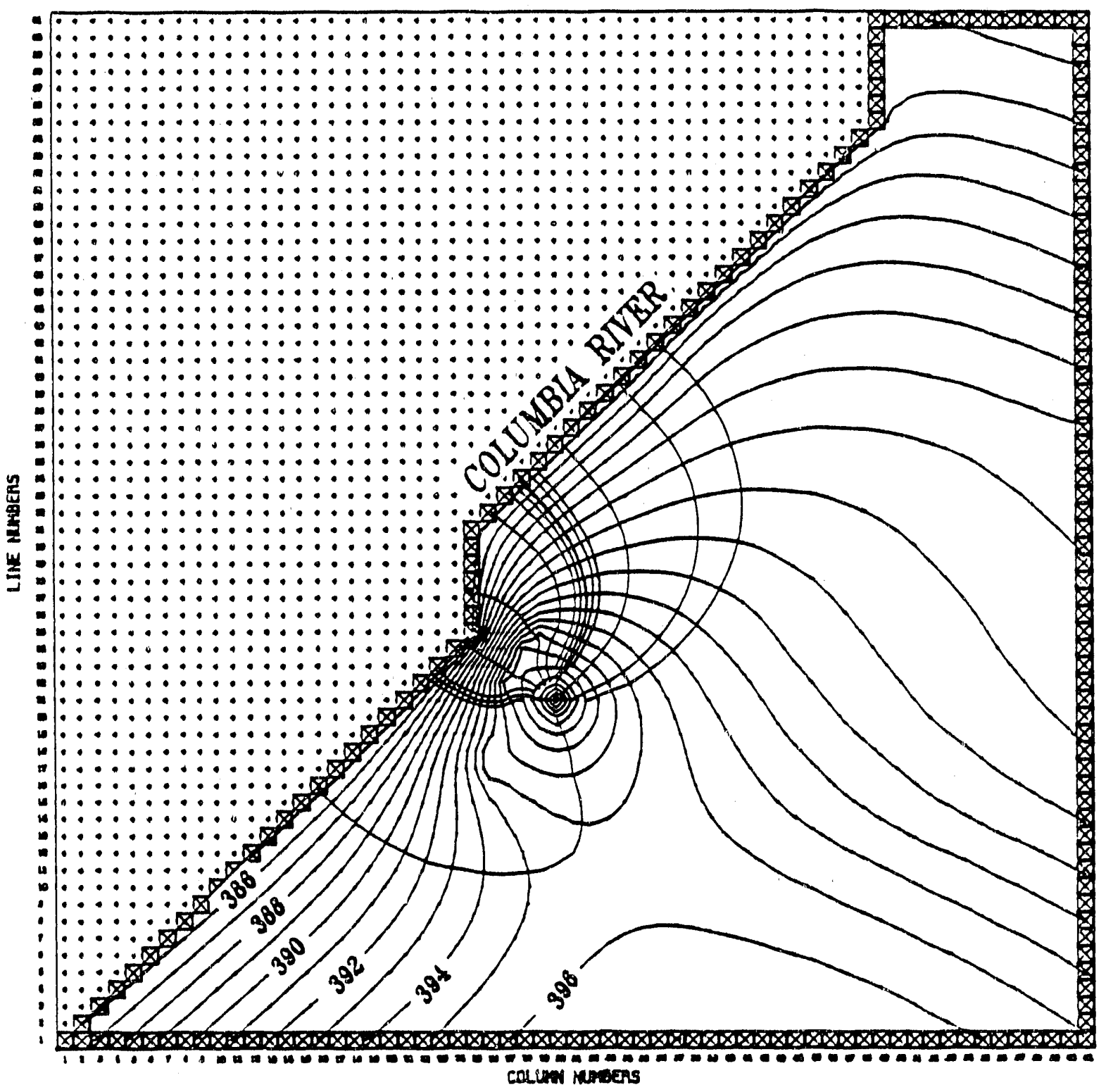

Figure 6. Ground Water Potential Surface with River Flow at 100,000 cfs -- Crib Flows Split 


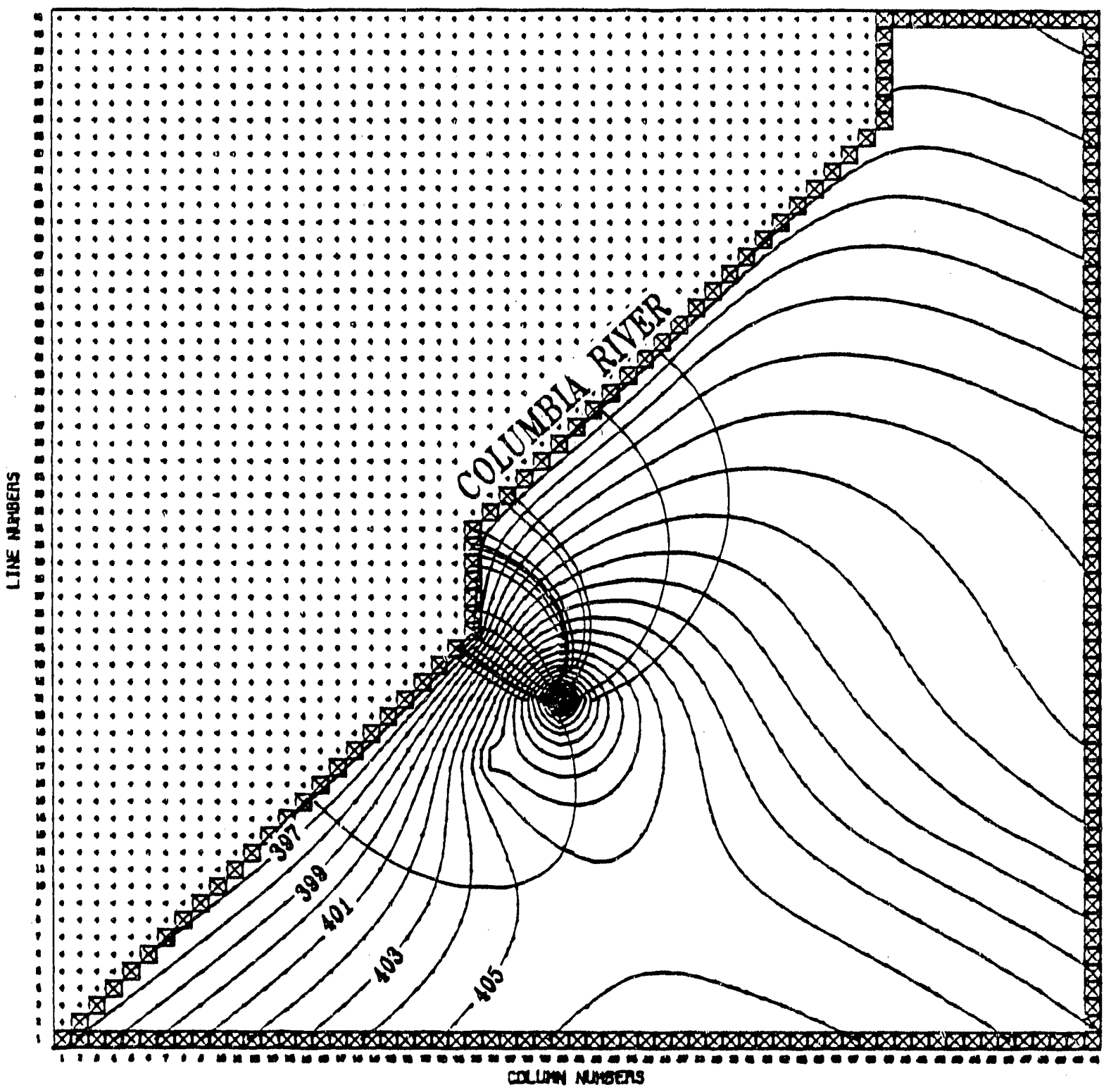

FIGURE 7. Ground Water Potential Surface with River Flow at 350,000 cfs -- Crib Flows Split 


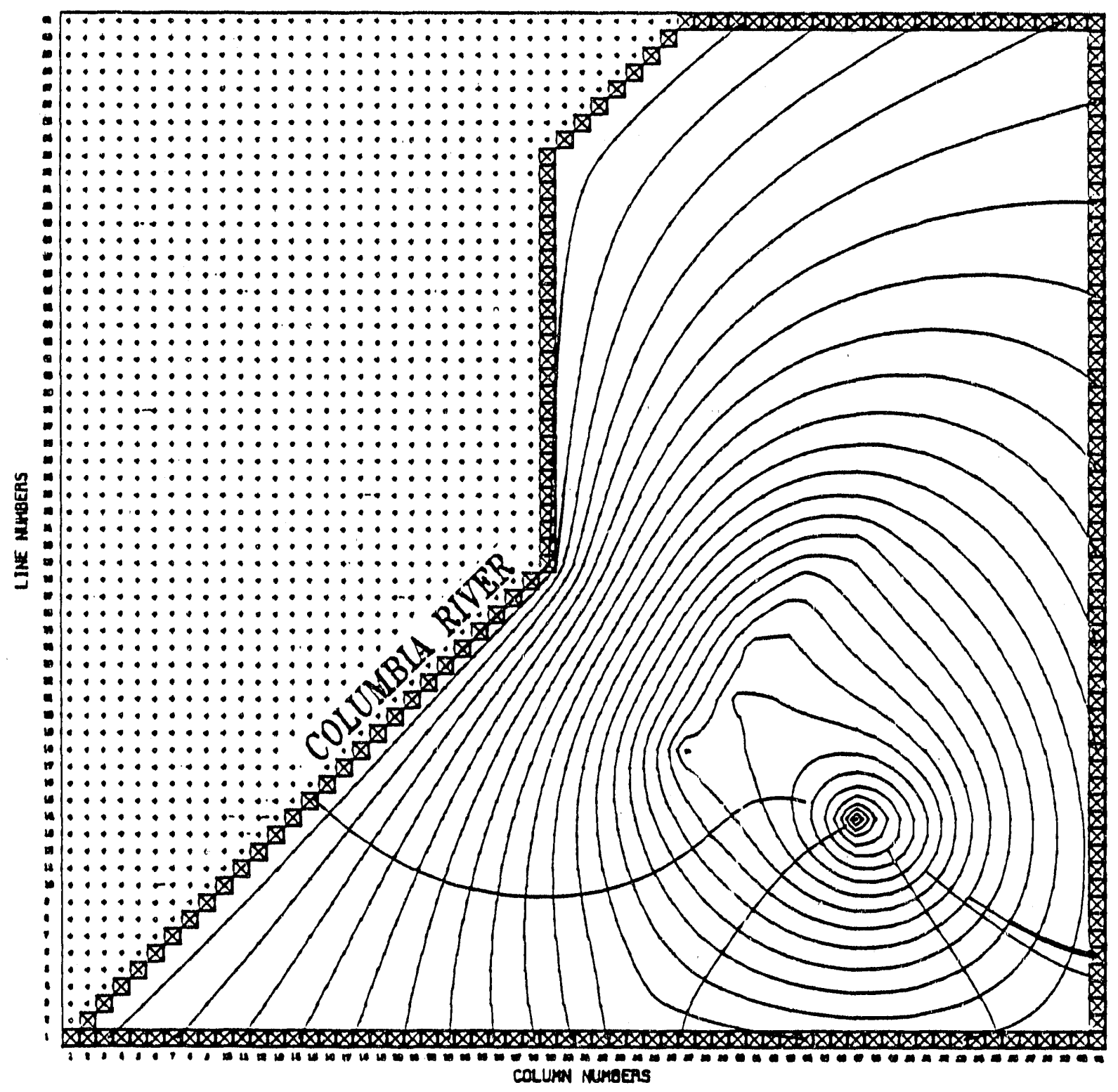

FIGURE 8. Ground Water Potential Surface with River Flow at 100,000 cfs with Crib Flows Split -- Expanded Scale 


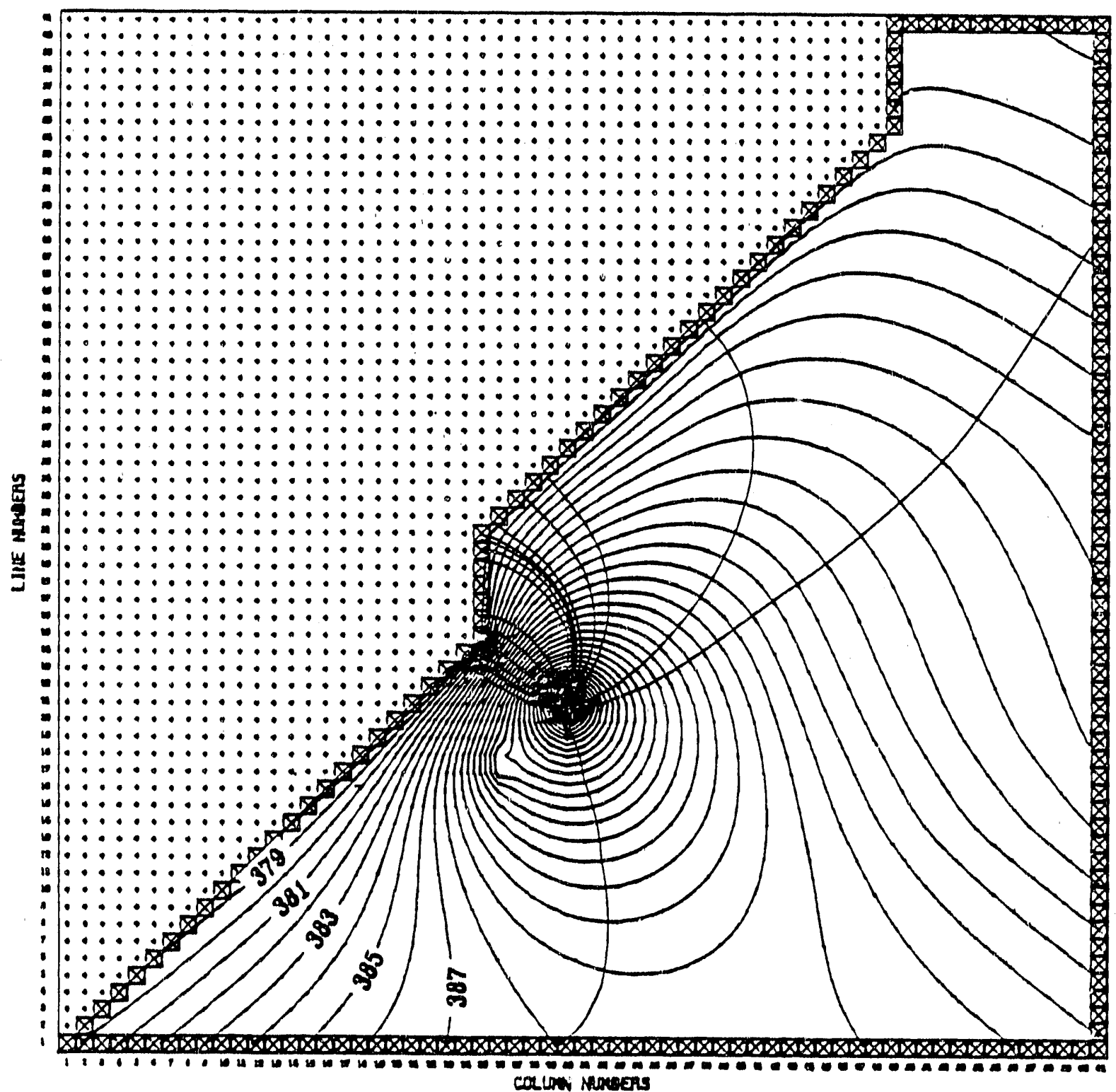

FIGURE 9. Ground Water Potential Surface with River Flow at 35,000 cfs -- Flow Diverted from Old to New Crib 


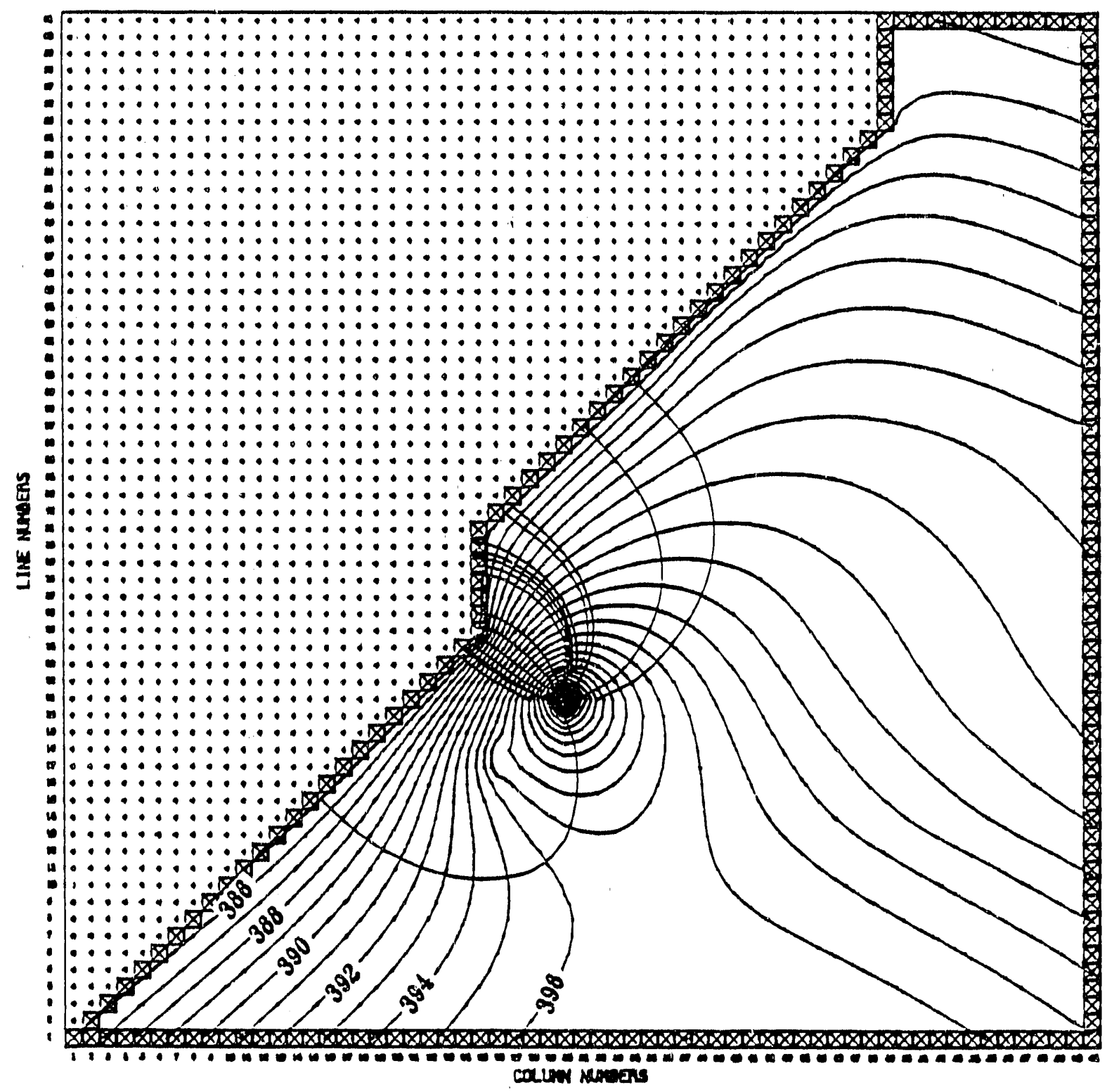

FIGURE 10. Ground Water Potential Surface with River Flow at 100,000 cfs -- Flow Diverted from 01d to New Crib 


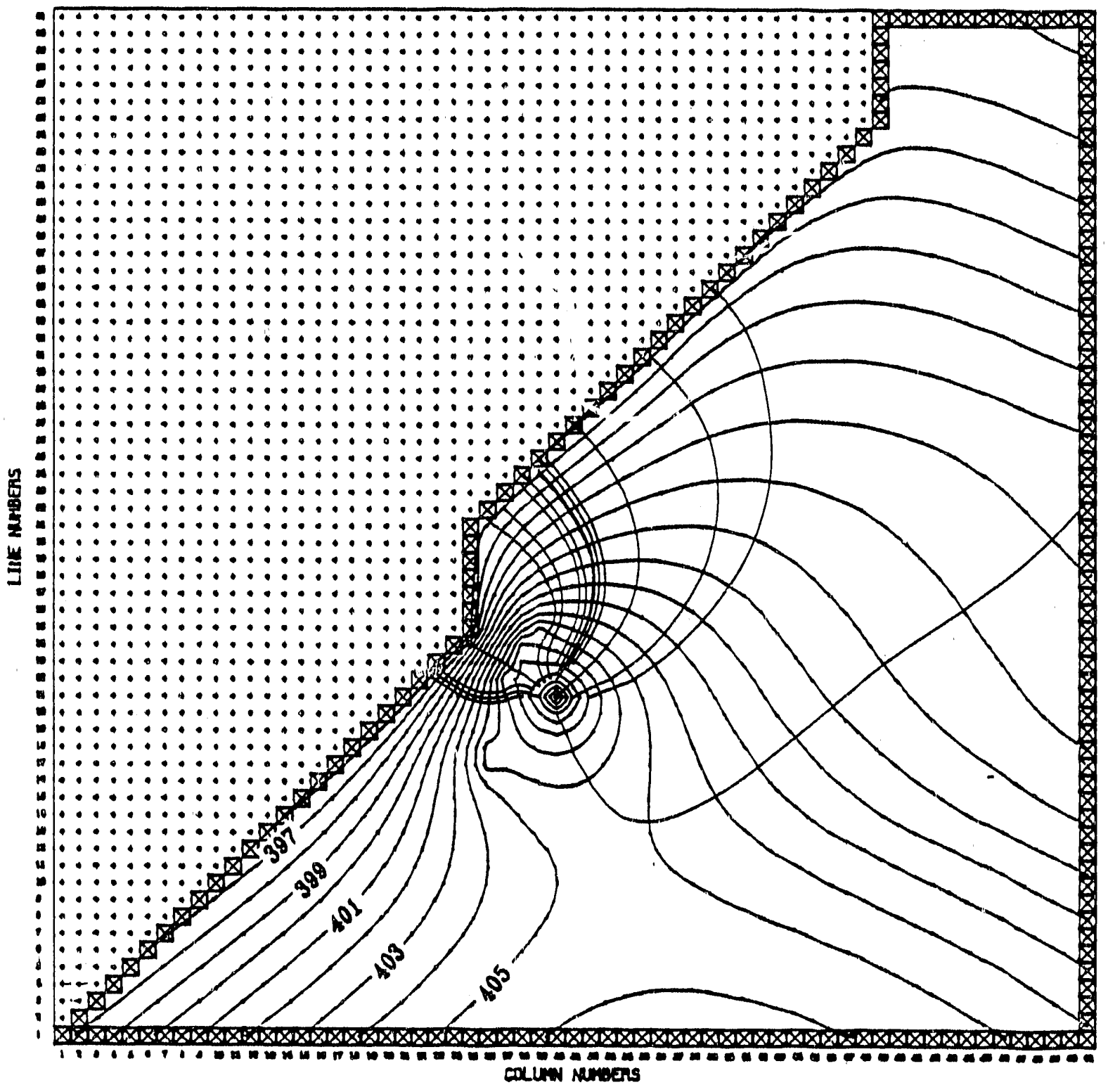

FIGURE 11. Ground Water Potential Surfide with River Flow at 350,000 cfs -- Flow Diverted from 01d to New Crib 
Phase III, Task 4 of 1301-N Crib Study - Examination of Possible Iodine-131 River Stage Relationship

INTRODUCTION

The objective of this task of the 1301-N crlb study has been to investigate and subsequently determine whether a relationship exists betiween the decontamination factor (DECON factor or DF) and river stage (elevation). Moreover, the scope of the investigation has been limited to the study of weekly averaged samples of I-131 collected on seven day sampling intervals and river stage developed from discharge measurements at Priest Rapids Dam.

The analysis proceeded in three stages. First, a plot of the concentration history, at both the springs and the disposal crib, was prepared (Figure 1a). Concentrations measured during perinds when the reactor was operating were plotted; values of I-13I less than the detectable 1 imit were not plotted. Secondly, an investigation of the DECON factor used to evaluate the effectiveness of I-131 attenuation was undertaken. Because the OF presently used (defined as the ratio of total curies delivered to the crib to the total curies arriving at the springs) fluctuates one or more orders of magnitude from week to week, it was felt that a less sensitive parameter might be more useful for evaluating the attenuation that takes place between the crib and the springs. Finally, various methods of comparing the concentration data with river stage measurements were performed.

ANALYSIS

Stage I

Examination of figure la reveals an apparent long-term trend in which the crib concentrations appear to be decreasing with time while the springs conceritrations appear to be increasing with time. This observation may be misleading; Figure lb clearly shows that the attenuation, expresssed as a normalized $D F$, does not steadily increase or decrease with time. The similarity in the graphs of the crib and springs concentrations indicates that, if the river stage does affect the observed concentrations at the 
springs, the effect is minor. However, there are pertods, most notably in the early spring of 1978 and in 1982, during whtch the crib and the springs I-131 concentrattons move in opposite directlons. The crlb concentration of January 24, 1979 is suspected to be in error by one order of magnitude.

\section{Stage II}

Close examination of Figure la also shows a time delay effect between the I-131 values at the crib and the springs. It was felt that if this tine lag were incorporated into the OF, a difierent trend might be observed. Figure 3 is a plot of the of with and without the time lag. A 7 day time lag was chosen because the sampling interval is 7 days. This is approximately the same as the accepted travel, time between the crib and the springs of 5 to 8 days. The DF was calculated by taking the ratio of twice the crib concentration over the springs concentration. This is the same prucedure UNC uses to calculate the of under the assumption of constant flow into the crib. The plot shows the time lag consideration to be of relatively little importance.

Other parameters were sought to quantitatively describe the attenuation taking place between the crib and the springs. A normalized decontamination factor (NDF) calculated as

\section{[Log (Crib Concentration)t-7 days - Log (Springs Concentration)t]}

$$
\text { Log (Crib Concentration) t-7 days }
$$

was chosen to represent the attentuation. Table 1 shows vearly average decontamination factors computed by UNC and by the normalized method. Both data sets show a decreasing trend with time.

The advantage of using a normalized decontamination factor is that the amount of attenuation is measured relative to the driving quantity. Through the use of the logarithmic function, the sensitivity of the decontamination factor is reduced. Examination of the normalized decontamination factor revealed that the decontamination factor used by UNC quantifies decontamination in a manner dependent upon the dose to the trench. For example, one might arbitrarily choose a lower limit to the NDF of 0.2 (see Figure 2). This transiates into maintaining the presently used OF above a value of 2 - (crib concentration).2 - which is a function of the crib concentration and hence not constant (see appendix). 
Stage III

During Stage III, vartous methods were used to assess the degree of correiation betiveen river stage and the $1-131$ data. The river stage data collected by UNC had been converted to a river flow rate (discharge) using a stage -discharge curve developed from measurements at Priest Raptos Dam. The original river stage readings were unavallable. River stage is highly dependent upon channel cross-section. Therefore, it became necessary to use a stage-discharge curve deveioped for the cross-section at the $100 \mathrm{-N}$ intake structure to calculate the water surface elevations adjacent to the springs.

Comparison of Figures 16 and 2 show that during certain pertods the vartables (NDF and river stage) behave simtlarly; most notable are the upward trends occuring in early 1978 and 1982, and the downward trends occuring in early 1977 and late 1981. In these few cases there appears to be a strong positive correlation between river stage and I-131 attenuation. At other intervals, (extending over several months) no long term trends are apparent, a) though at a few points the vartables diverge such as in May, 1979. Figure 4 is a plot of the NOF versus river stage; no apparent relation exists. Figure 5 compares changes in NDF with changes in river stage at corresponding times; again, there appears to be no functional relation between these variables.

As a final attempt to find quantitative evidence of a relation between river stage and I-13I attenuation, cross-correlation analyses were carried out. Table 2 presents the results of cross-correlation analyses. The confidence level determines the significance of the cross-correlation coefficient. A high confidence level implies that the correlationcoefficient is statistically significant. In cross-correlating two data sets we are testing the hypothesis that the two sets are independent of each other. For example, the first entry in Table 2 yields a correlation coefificient of .5021 at the 99.9 percent: confidence level. Hence, with 99.9 percent confidence (or with .1 percent chance of being in error) we reject the hypothesis that the two data sets are independent. The degree of dependency $(.5021)$ is relatively strong. The correlation coefficient will range from 0.0 (zero correlation) to \pm 1.0 (perfect correlation). Since crib concentrations are independent of flow rates in the river, one would naturally expect a higher correlation betiveen the springs concentration and 
river stage than between the crtb concentration and river stage. The correlation analyses show this to be true. For the last entry in Table 2, the cross-correlation coeffictent becomes statisttcally significant at the 39 percent confidence level. In other words we are confident that the correlation (-.1184) is not a result of randomness, and that 39 percent of the time we $c$ an expect to observe this weak dependency. Furthermore, the river stage - springs concentration cross-correlation coeffictent is negattve indicating that an inverse relationship exists. Indeed, one would expect the springs concentration to decrease with increasing river stage if dilution or retardation were enhanced by the increased stage.

\section{EVALUATION}

The focus of this research has been on finding an explanation for the decreasing trend in I-131 decontamination factors. The objectlve of this phase of the study has been the identification of any relationship between river stage and DECON factor. A cursory examination of figures $1 b$ and 2 reveals pertods of increasing river stage that correspond with increases in the DECON factor; however, in-depth analysts of the data (supplited on seven day sampling intervals) provides only weak evidence of a causal relationship between river stage and the DECON factor. The relationship may be statistically weak due to the temporal observation interval or seven days and the potentfally more rapld response of the ground-water system; 1.e., the resolution of the data may be too coarse to capture the correspondence between river stage and the DECON factor. In light of the data no conclustons can be drawn from the analysts cornpleted to date.

Additionally, it has been noted that the sampling well (100-N-BT) is not perforated and that the springs concentration values are taken from water approximately 16 feet below the water table. Contaminants, in general, travel at or near the water table surface (assuming they enter the ground-water system through the unsaturated zone). Noting the fast travel time ( 5 to 8 days from disposal crib to river springs) and the elevated temperature (approximately 20 to $30^{\circ} \mathrm{F}$ above the ambient ground-water temperature), vertical dispersion may be too small to assure the concentration 16 feet below the surface is representative of the entire plume. It 
is our optnion that if nigher concentrations of I-1,31 exist and are not being observed at the sample point (30 feet underground at well 100-N-BT), then they extst between the free surface of ground water and the sampling elevation ( 374 feet).

RECOMMENDATIONS

Implementing the following recommendations will provide a more thorough analysts of the problem and may produce significant results.

- UNC should consider collecting and analyzing any data pertaining to I-131 releases and springs measurements spaced closer together than the 7 day sampling interval. Espectally useful would be data corresponding to a slug release such as would occur during a fuel fallure. Curves representing the $1-131$ injection at the crlb and the response at the springs may substantially contribute to an understanding of the problem.

- It is recommended that ground-water samples be taken only a few feet below the water table near well 100-N-8T. The I-131 concentration in these samples would indicate whether higher concentrations exist above the present sampling level located 16 feet below the water table. This could be accomplished by installing a plezometer a few feet from well 100-N-BT to a depth of approximately 16 feet (14 feet to the water table plus 2 feet) and taking grab samples on a regular interval. Particularly useful would be a program of grab sampling beginning just before startup of operations and continuing until the I-131 in the groundwater system has stablitized at an elevated level. Any significant difference between the concentrations taken from samples in the well and samples from the plezometer would indicate that the well (100-N-8T) may not accurately reflect the plume concentration.

Alternately, grab samples could be taken from running spring water at the seepage face on the river bank below well 100-N-8T. However, this has an tnherent disadvantage: It is not possible to take grab samples at the seepage face during pertods of high river stage because the seepage face becomes inundated with river water. Hence, there can be no comparison of grab samples with well samples to determine conjectured dllution/retardation effects assoctated with high river stage. 
- To better understand the attenuation observed a long-term study should be instituted to determine the detalls of flow in the vertical profile between the 1301-N disposal $\mathrm{cr}$ tb and the Columbla Rtver. The cunceptual model development necessary to fully evaluate the river stage dependence of springs concentrations would include a tivo-dinenstonal mode 1 for a vertical cross-section of the ground-water flow path between the disposal crib and the springs. Such a conceptual model and its computer implementation would examine the vertical distribution within the groundwater system of contamination originating from the $1301-\mathrm{N}$ disposal crtb. Engtneering design of the sampling well (100-N-8T) could be revtewed to determine if conservative estimates of 1-131 are being obtained from the present monttoring system for all river stage.

The development of the conceptual model and its eventual computer implementation would require a substantial data base. properties of the hydrologic system would require vertical definition. This study would involve data collection for parameters of the unsaturated and saturated transmisstve zones; installation of new wells and well tests would be necessary. Data necessary for the validation of the model would include vertical profiles of temperature, I-131, and perhaps I-133 concentrations. 
WHC - SP - 0377

TABLE 1. Yearly Average Decontamination Factors

\begin{tabular}{lcc} 
Year & $\begin{array}{c}\text { Average } \\
\text { UNC DF }\end{array}$ & $\begin{array}{c}\text { Average } \\
\text { NDF }\end{array}$ \\
\cline { 2 - 3 } 1974 & 210 & \\
1975 & 240 & \\
1976 & 245 & .43 \\
1977 & 130 & .37 \\
1978 & 150 & .37 \\
1979 & 170 & .34 \\
1980 & 120 & .35 \\
1981 & 50 & .31
\end{tabular}


TABLE 2. Cross-Correlation Analysis Results

Variables Correlated

Crib Concentrations

vs

Springs Concentrations

Norma 1 ized DF

vs

River Stage

Crib Concentrations vs

River Stage

Springs Concentrations vs

River Stage
Correlation

Coefficient

0.5021

0.3021

0.0624

$-0.1184$

$89 \%$

Level

$99.9 \%$

$99.9 \%$

$59 \%$
Confidence 

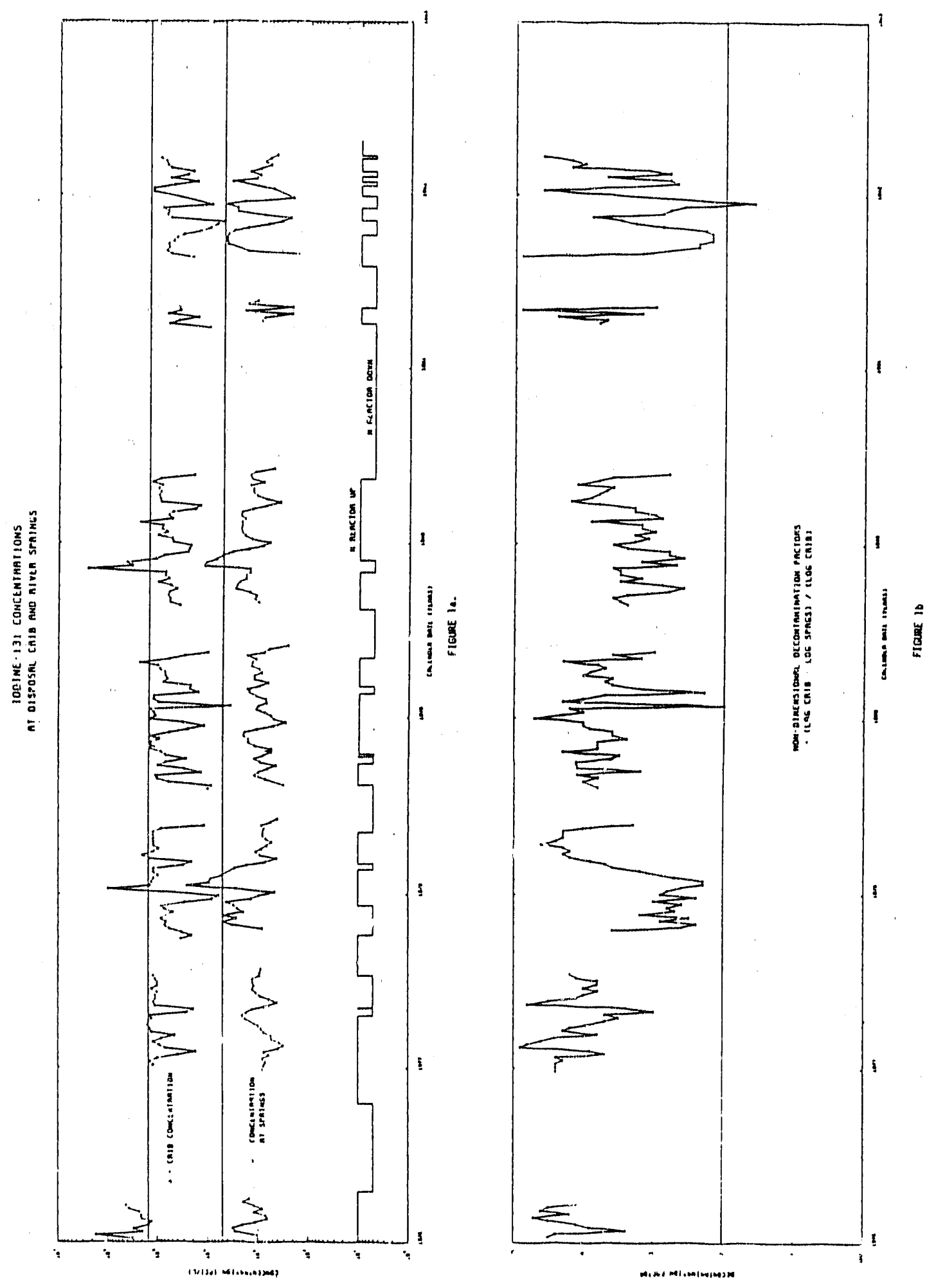
WHC-SP-0377

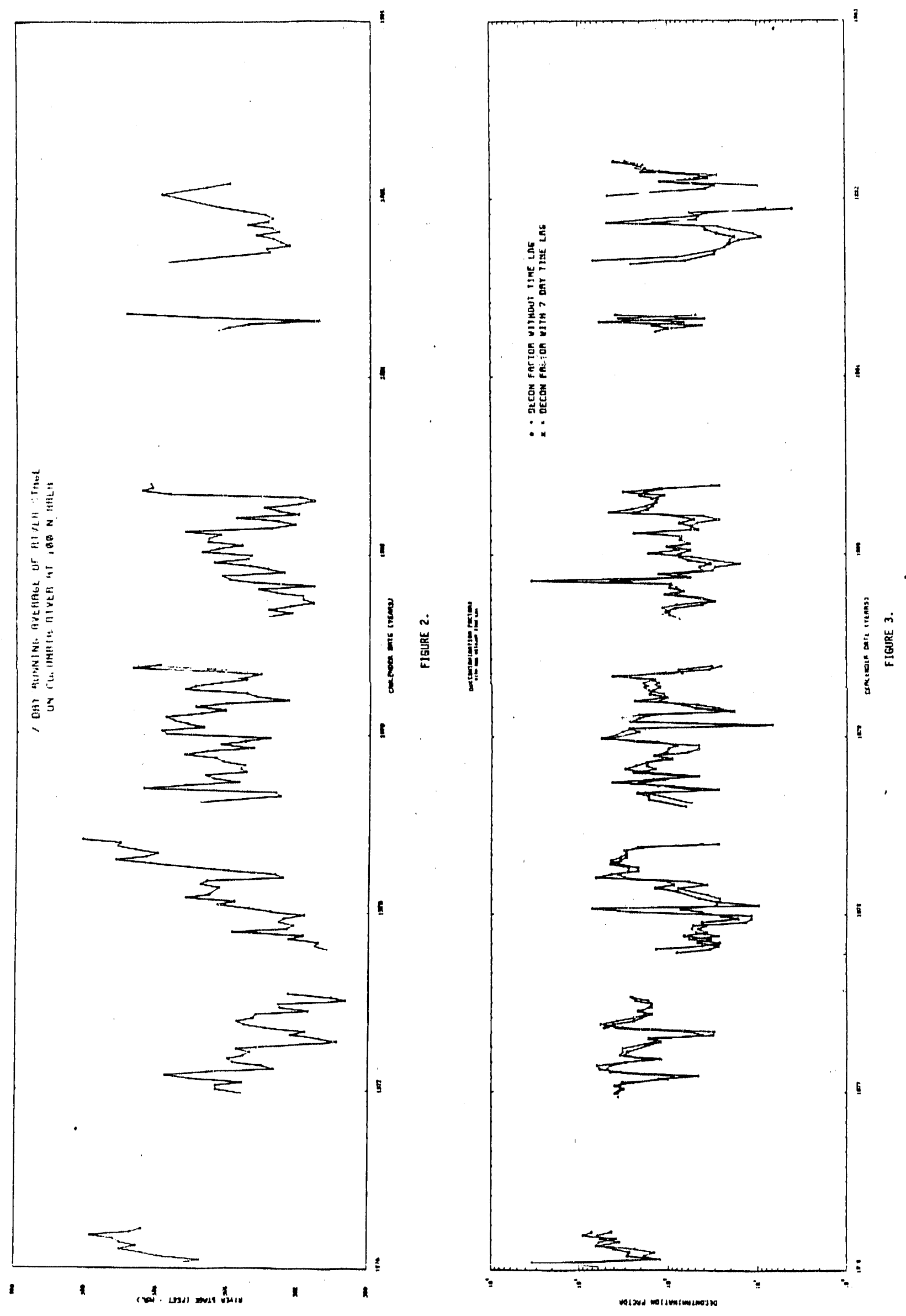


WHC - SP-0377

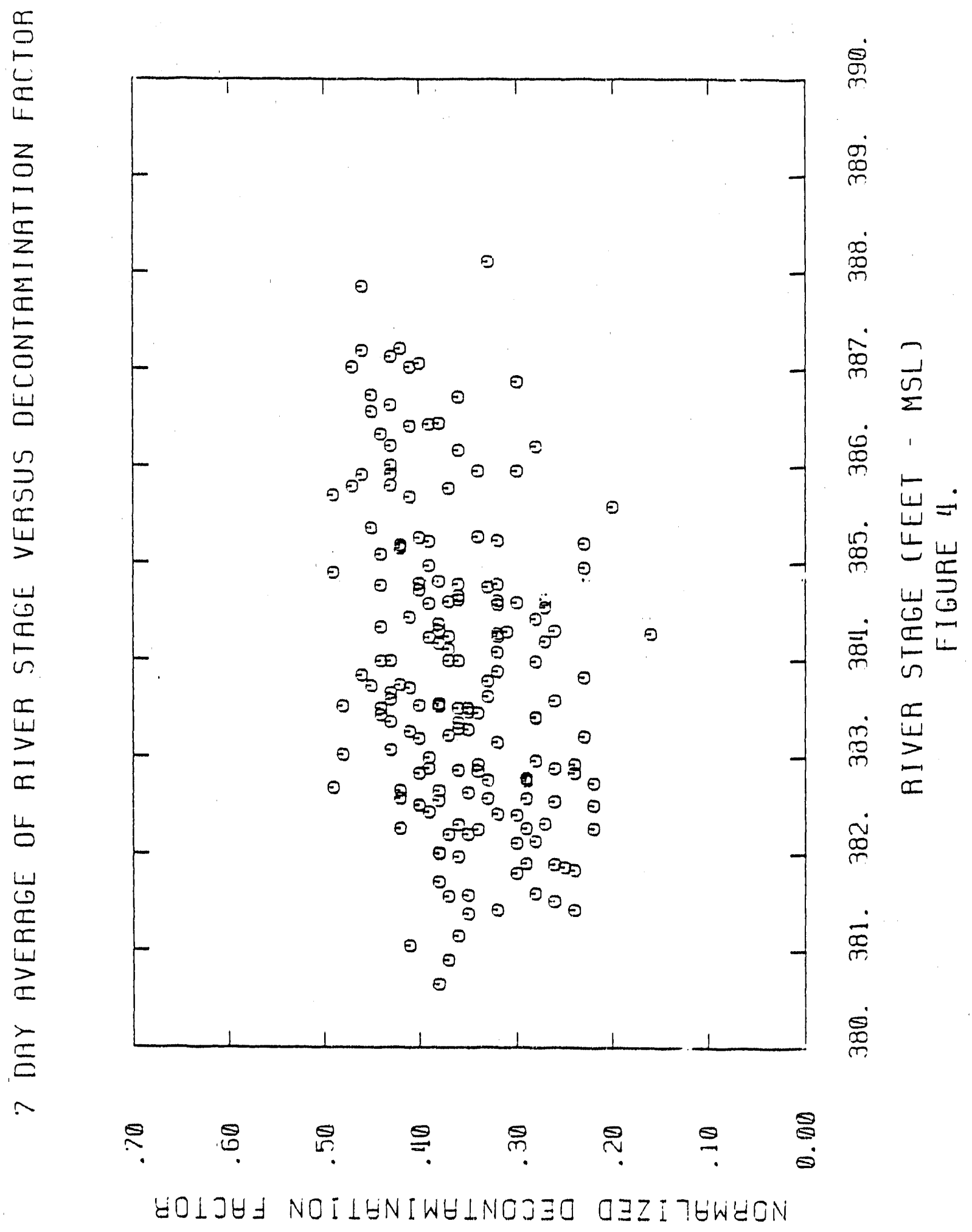




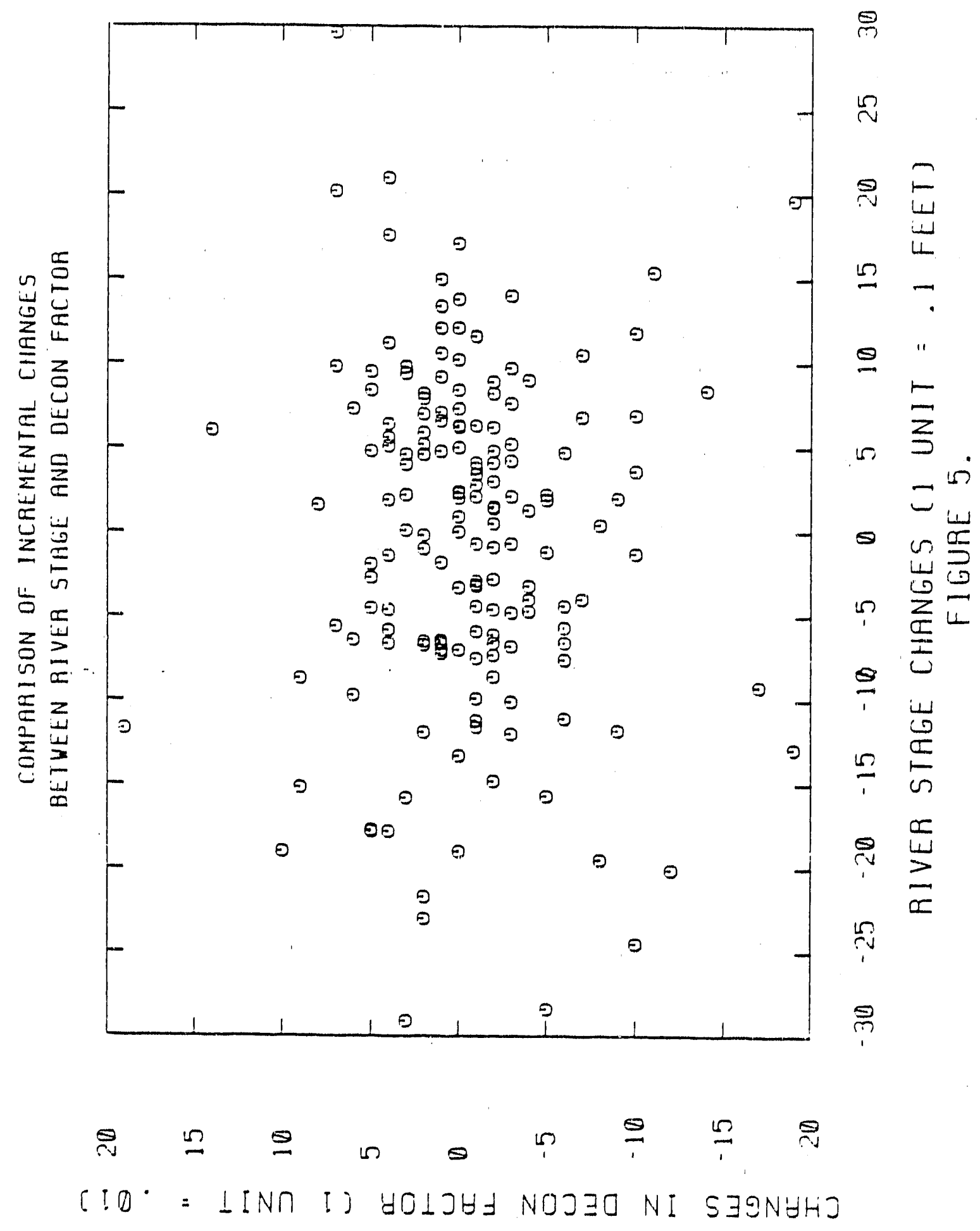


APPENDIX

$$
\begin{aligned}
& \text { UNC OF }=\frac{\text { Total curies to crib }}{\text { Total curies to springs }} \\
& =\frac{\text { (Crib concentration) (flow into crib) }}{\text { Springs concentration } \pi / / 2 \text { (flow into crib) }} \\
& \text { Let } C=\text { Crib concentration } \\
& S=\text { Springs concentration } \\
& \text { Under constant flow conditions UNC DF }=\frac{2 C}{5} \\
& \text { Whereas NDF }=\frac{\log (C)-\log (S)}{\log (C)} \\
& \text { Make NDF }=\text { constant }=.2 \\
& \text { then } \log (C)-\log (S)=.2 \log (C) \\
& \log (C / S)=\log (C \cdot 2) \\
& C / S=C \cdot 2 \\
& 2 C / S=U N C \text { OF }=2 C \cdot 2
\end{aligned}
$$


WHC-SP-0377

药崖

$0000000=00$

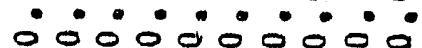

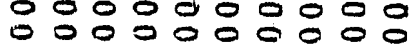

$=100000$ in

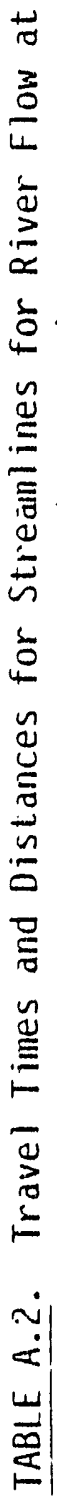

$\frac{3}{0}$

08

ᄒ̀

$\stackrel{0}{=}$

플

$\pm$

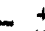

은

๑

밍

出

$5 \cdot \frac{1}{x}$

믇

$\stackrel{\mathscr{W}}{4}$

$-8$

$-8$

\о

$=\pi$

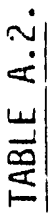

iี

$=2$

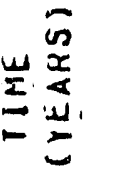

$=\because 0: 0000 \simeq 0 \quad \overrightarrow{0}$

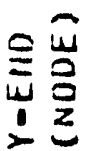

manmina gon

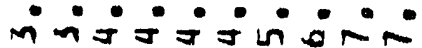

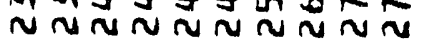

五

D $2 m 00 \sigma a \sigma a$

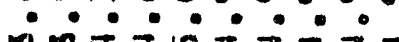

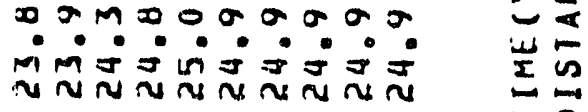

กิ

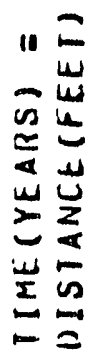

لِّ

象

$x \propto$

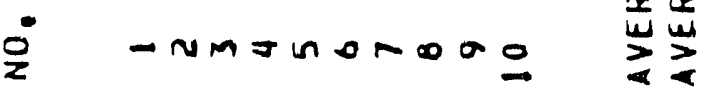

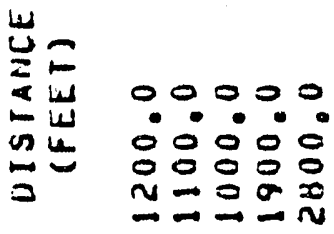

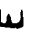

W 00000

m 00000

T 00000

$\checkmark$ o in m $\sigma 20$

$\underset{0}{\stackrel{0}{*}=}$

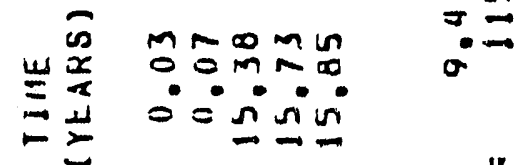

30

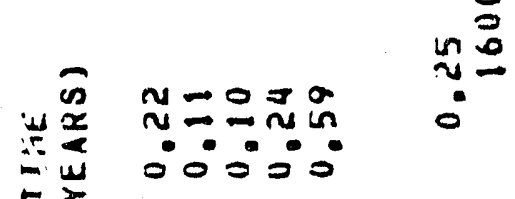

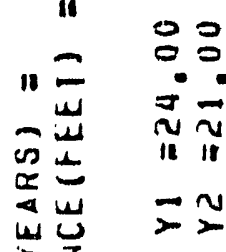

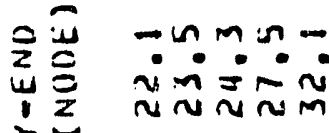

造坚

추 $\sim \infty \infty \%$

ㄴ.

i"응

$-\infty$

00

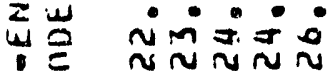

的

$\Xi \Xi$

00

uñun

㟧

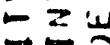

(0.0

象

$x$

क을

a 111

준

$\stackrel{0}{2}$

$-n m=n$

w

?․

$\circ 0$

$\sim m$

$\nexists \underset{x}{x}$

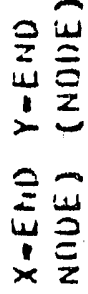

$\because \div ? \div$

$\because \div=0$

$\| F$

की it

$\simeq$

4

난는

鱼管

$\times \underline{z} \sim \sim 0$ in in $=\frac{2}{0}$

- Nman $\geq 2$ 
us

$\underset{2}{2}$

in 0000000000

nL 0000000000

- 0 - 0900000000

立造

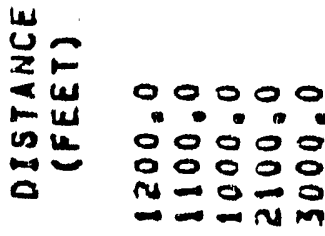

$\pi$

$5 \cdot$

밈

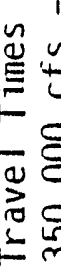

$\dot{m}$
$\dot{\square}$
$\dot{\square}$

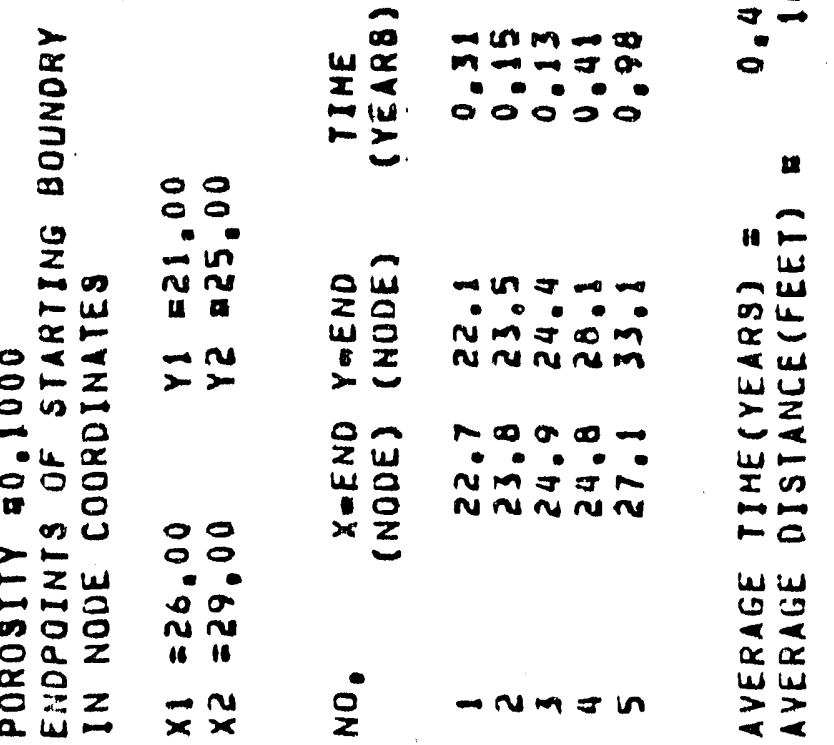

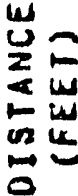

00000

- . - . 00000 인요 $m n n$

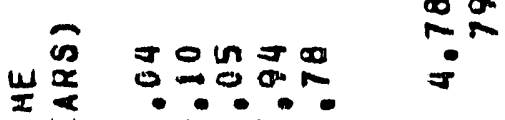
In $0^{\circ} 0^{\circ} \infty N$

80

$\because$ - $\quad$ ए

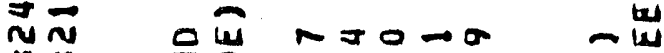

* $=0$ isu

$=0 \quad$ แ

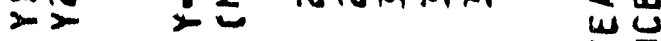

0 $00-\infty-2 \leq$

$\sum u$ 난

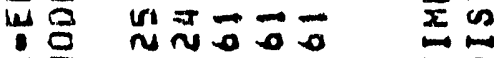

$00 \times \frac{1}{0}$ N

0

00

$n$

$x \frac{n}{x}$

us un

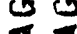

$\alpha$

$\frac{0}{2} \quad-n m=n \quad \geqslant \geqslant$ 
WHC-SP-0377

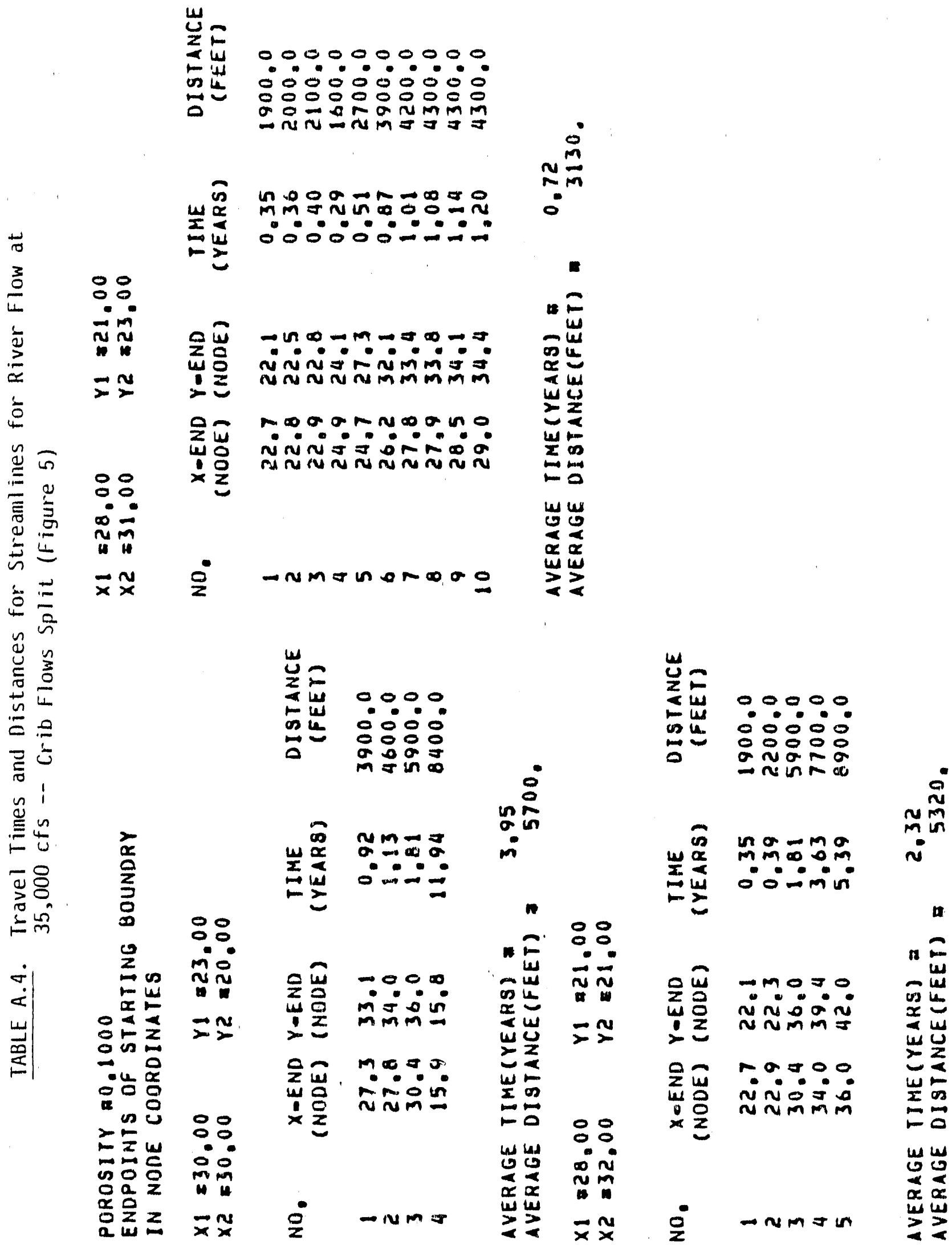




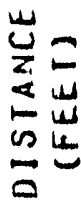

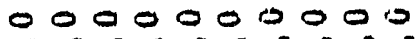

i.

2000

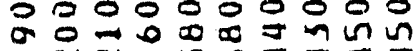

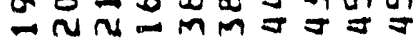

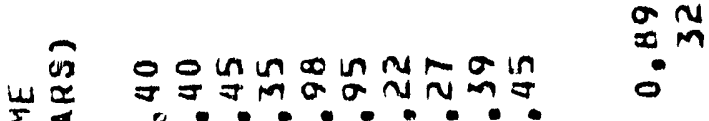
in 11

03

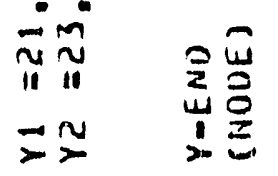

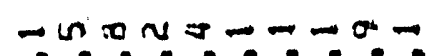

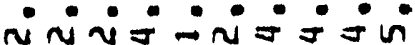

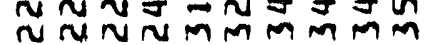

용 $\quad \frac{1}{2}$

20

$r \approx \sigma \sigma \sigma-\sigma o m$ iñ $\dot{\sim} \dot{0} \dot{0} \dot{0} \dot{0} \dot{0}$ unN $\sim \sim \sim \sim \sim N$

11

舟

$x$ is

$\sum w$

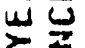

2

wi

10

س

0

x $\frac{x}{\alpha}$

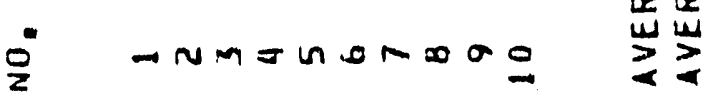

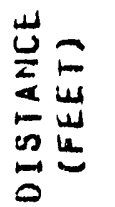

0000

0000

o 0

崔

$\underset{2}{2}$

잉

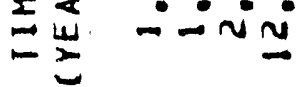

$\frac{1}{2}$

$\sum_{n=0}$

$2 \pm$

$3 \leq 2 \leq 2$

$0 \pi=$

는

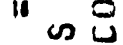

$=\infty$

$= \pm$

00

00

ci:

î

20

른

$\vec{x}$

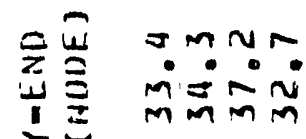

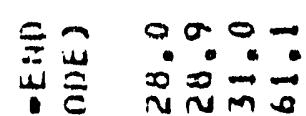

$x z$

: $\quad-n m=$

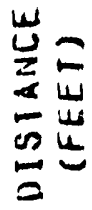

00000 :0ं0ं0

- 0000

$\sigma \sim m a$

$\sum_{i=1}^{\infty} \quad 0=0 \infty i n$

$n$

90

11

en

感 $\Rightarrow$

$\vec{\pi} \underset{\pi}{\pi}$

$\sum_{i}^{\omega}$

$\sum_{\bar{\Sigma}}^{w}$

$\rightarrow \mathrm{NO}^{-}-\frac{\omega}{4}$ iñ்-í $\sim N m=2$

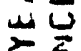

立

wi

$\lim _{x \rightarrow \infty}$

$\because 0$

$\stackrel{0}{0}$

ص⿺

40

in

$0 ?$

$\sim \sim \vec{m} \sim$

$=0$

سن س

$\infty \pi$

il in

$\boldsymbol{x} \underset{w}{x}$

w

$=2$

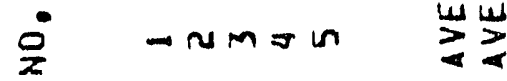




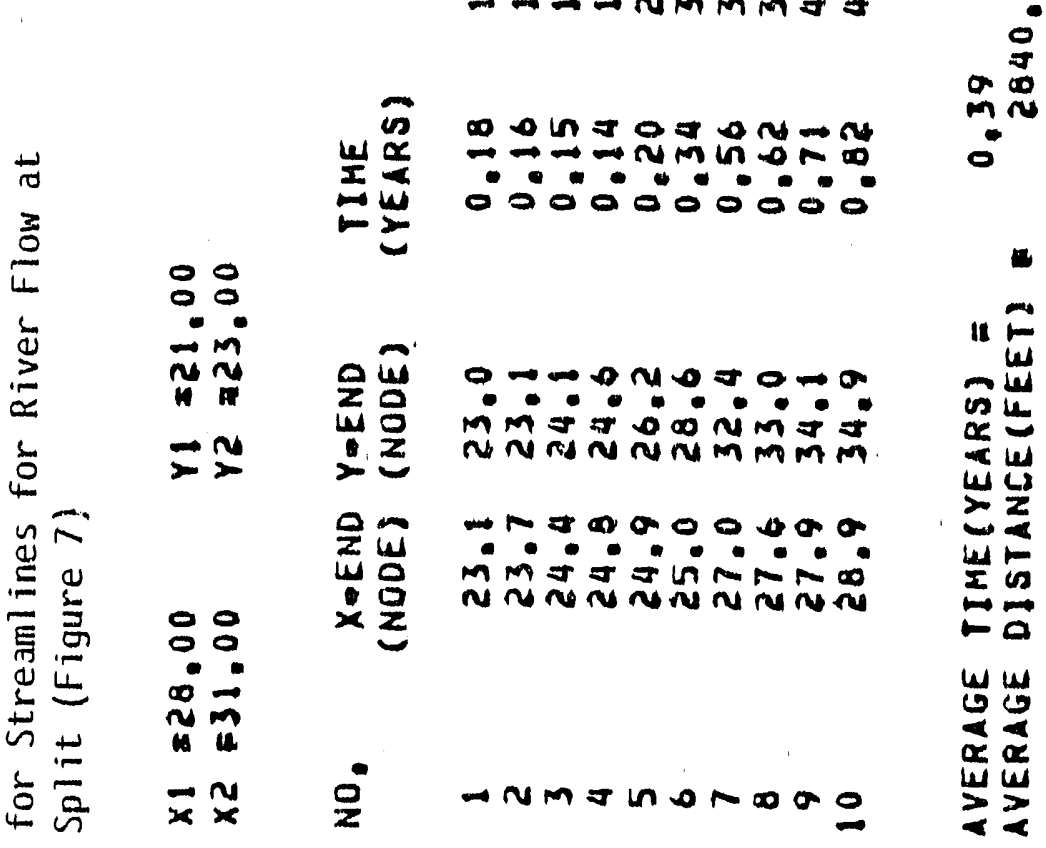

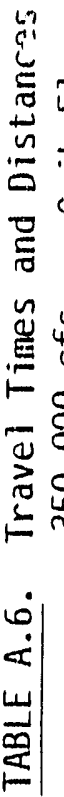

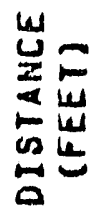

o 00000000

- * - .

$\because 080000000$

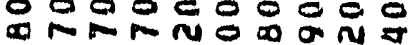

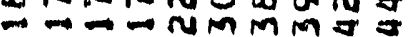

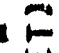

in

$\infty$

is 4

2

15

$\rightarrow 0$

w

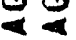

in

$x<$

$\omega$

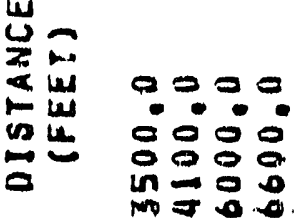

는

$\sum$ in

Iw

जU 00000

ㄴ. 00000

$\infty 00 \pi$

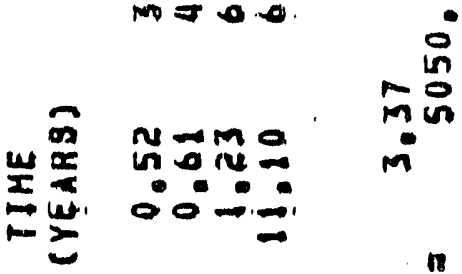

80

10

$\sum_{i \infty n} M$

-U แ

$=x$

능

11

89

$-$

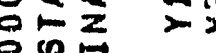

in

- u a

- 00

a 8

$-\infty$

$-z \omega$

등

क a

$0 \frac{0}{2} \geq-\infty$

08

00

0

$m$

a. un $=\vec{x} x$

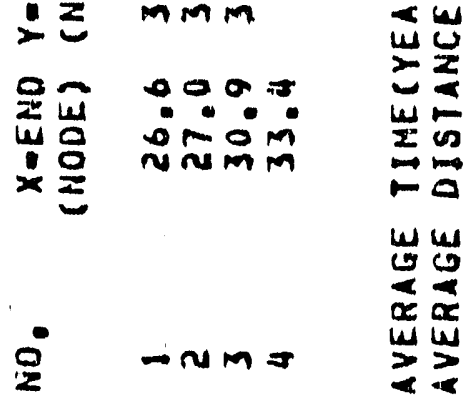

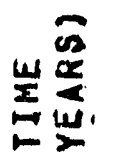

- $\ln \frac{1}{0}$

- Mruma m

- $00-00$

$\sum_{i=1}^{\infty} \sum_{\infty}^{\infty}$

$00 \quad \times \frac{1}{2}$

$0, \infty 0$

2

if $\underset{\text { if }}{\mathrm{r}}$

$=\infty$

ñm

$\sum_{m} \frac{1}{2}$
$x \frac{0}{2}$

$-\infty 0002>2$

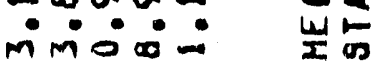

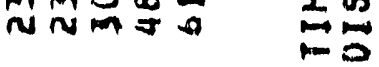

-

u

学

\#x $\quad$ o 
0000000000

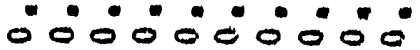

응영영영영영

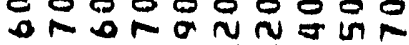

- - - NMMMM

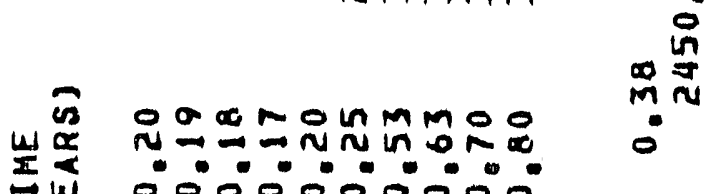

$0000000000^{\circ}$

$\sum_{0}^{0}$

$\stackrel{0}{0}$

is

$=n$

$\sum_{i=0}^{0}$

nONMNOOMM-

- $-\cdots$

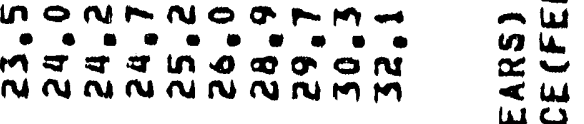

$\sum u$

w嵅

$2 \frac{1}{2}$

w正

$\underset{10}{2}$

$\therefore: \quad \quad \therefore \frac{0}{2}$

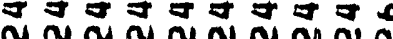

$-0$

$4 w$

00

खे

F

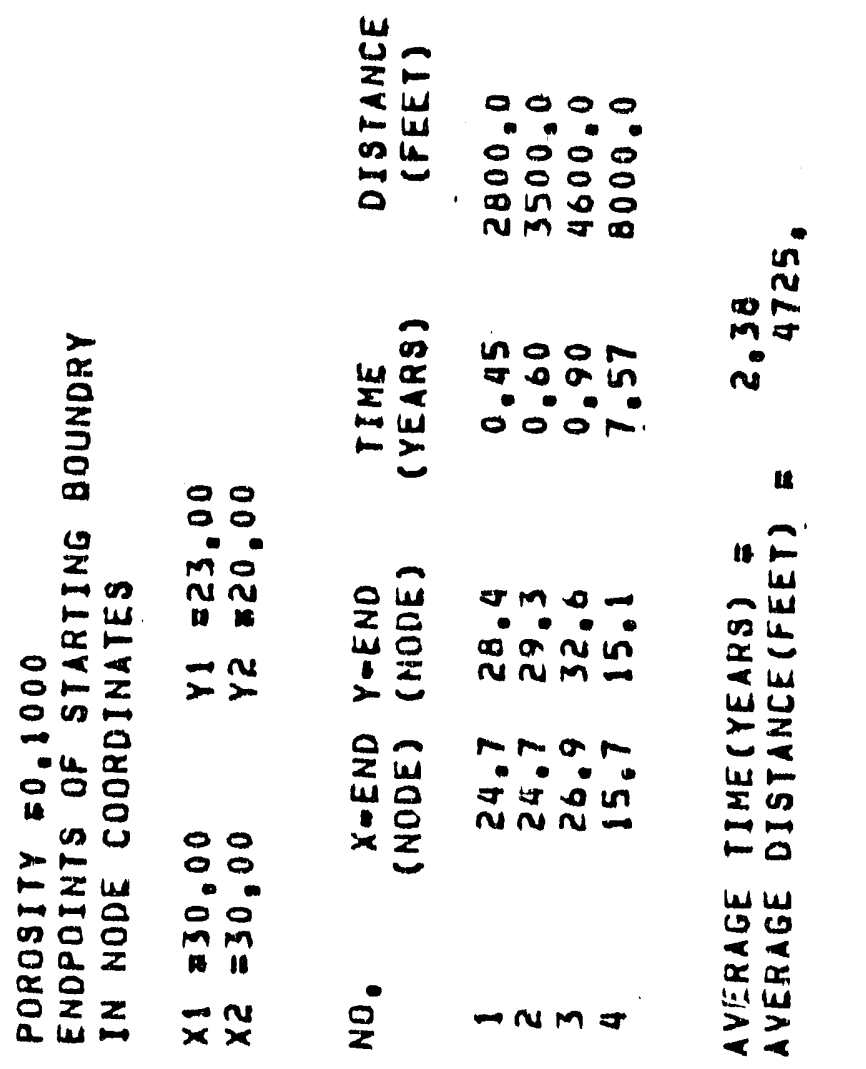

용

00

$\vec{n}$

$=\pi$

$\sum_{i=1}^{\circ}$

$\sum_{1} \frac{0}{2}$

in $-0 n 0$

minis:

ñ̉mo

C. ONO-O 2E

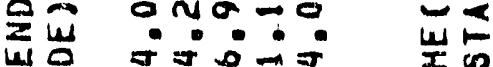

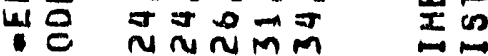

: 즈 NNNMm

:

$\infty \mathrm{N}$

तin in

Mn $D$ D

$\bar{x} \ddot{x} \quad 0 \quad$ onm 

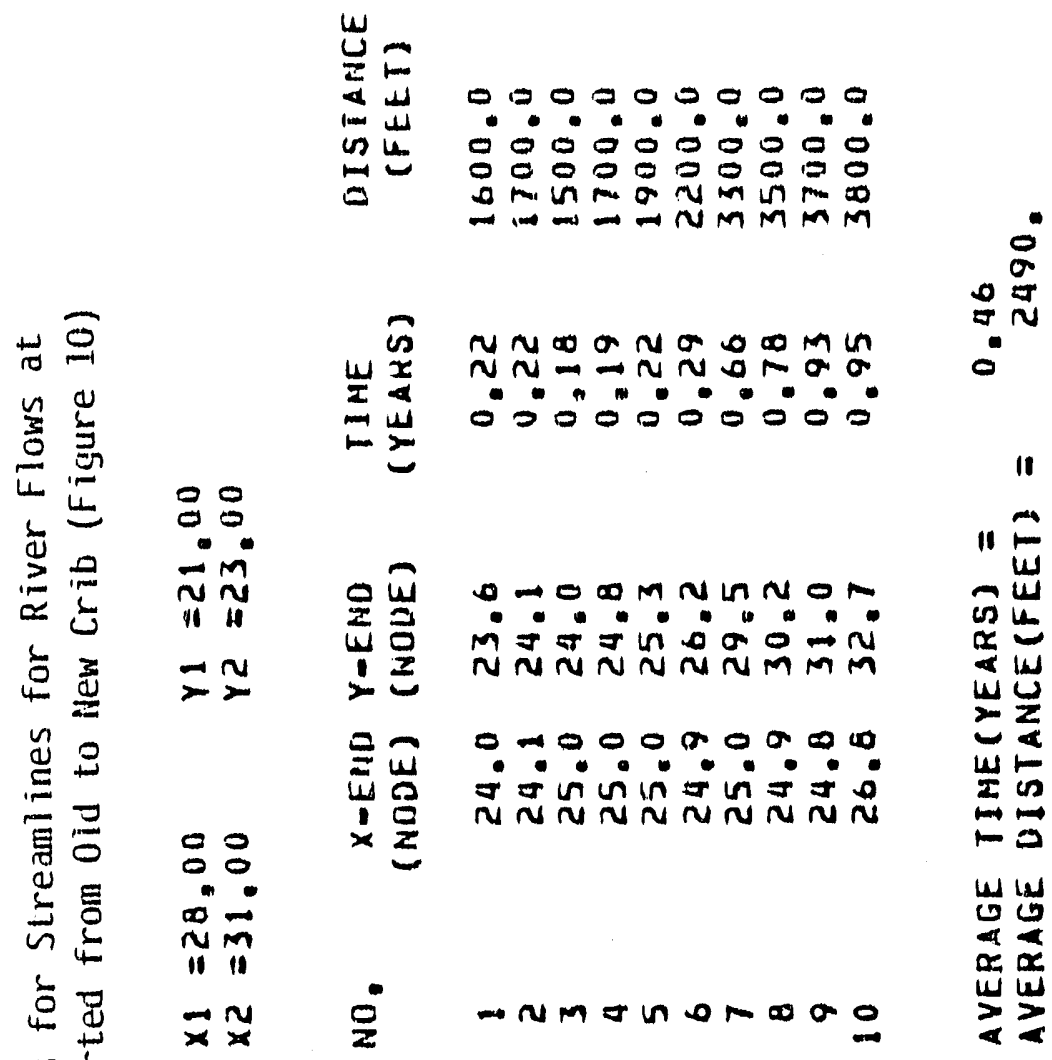

mos

U

का

w

20

w

m

4 I

a

wit

-

य

它 $\geq$

व

学

巳一ำ

巡

$-8$

$>0$

iv

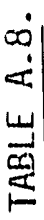

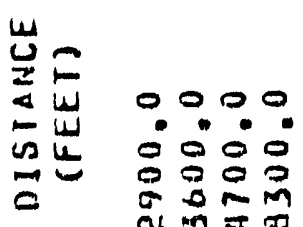

$\underset{2}{2}$

00

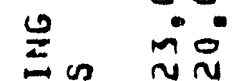

EN

$x=$

$0 \leq \leq ⿻ 一$

$\approx 2$

내 $\infty a-0$

แ

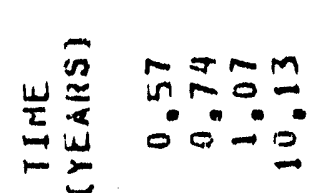

$\stackrel{\substack{n \\ m}}{\stackrel{n}{\square}}$

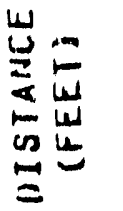

00000 $\therefore 0^{\circ}=$ 00009

0070

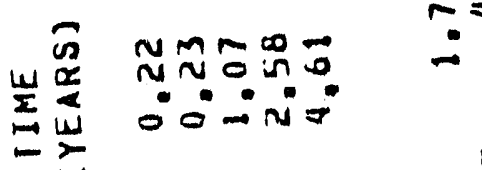

10

II

0

11 10

(1) W

(9)

$\approx$

出

$=\infty$

는?

$\because$

0 is

-

(1) 0

c)?

$>1$

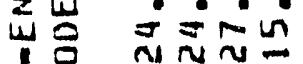

is

$\equiv$

- $=\omega$

un

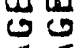

$\alpha$

ज泟

는

$\frac{x}{2} \frac{2}{2} z=\frac{x}{x}$
30
00
$0 N$
11
11
$-N$
$x x$

岂

a $\sim \sim n$

Mํmin=

퐁

ommax $\quad \geq z$

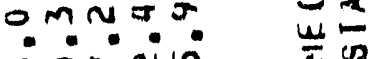

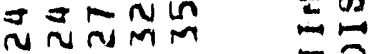

$\times \geq$

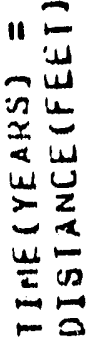

岕

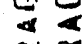

a. $x$

i $\quad$ - 


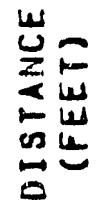

0000000000

:

000000000000

Q 0000 in $r 0=$

$\rightarrow-m$ n $m$ in $m$

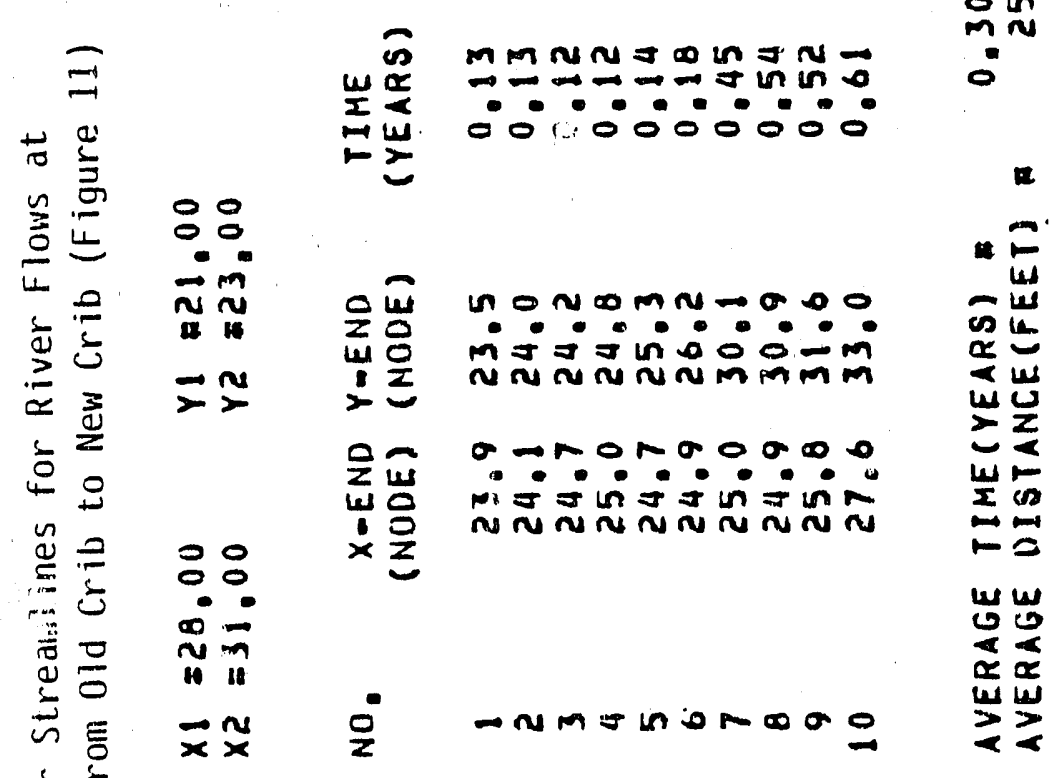

w

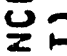

In 0000

- If

on 0000

$\therefore=200$

正

ज!

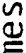

$\stackrel{\varrho}{=}$

$\pitchfork 8$

I.

$\dot{0}$
$\dot{<}$
$\dot{\infty}$

$=\frac{1}{2} 00^{\circ} 0^{\circ}$

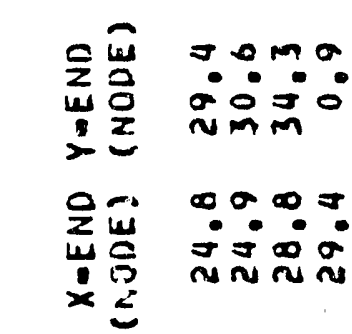

元

:

용

w

占必

这

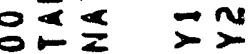

-4ㅇํㅇ

os

>

$=z$ w

옹응

울

$\sum_{a} \sum_{i=1}$

$\circ-$

요요

$\because x$ $\stackrel{\circ}{\dot{v}_{0}^{n}}$

a

2

in

con.

w

$\sum \geq$

紧

$\sum$ in

-

u w

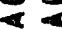

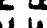

2
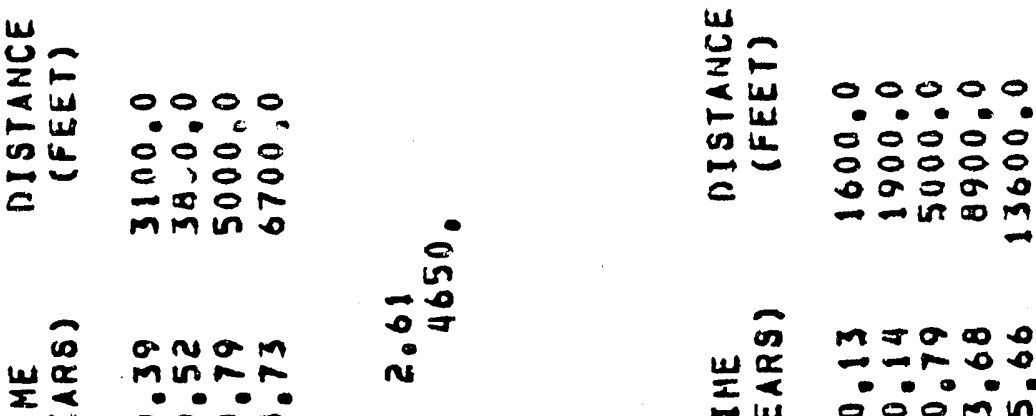

क $m=0 \%$

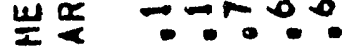

$\underbrace{}_{\substack{\infty \\ 0}}$

$\Rightarrow$ 岸 $000 \mathrm{~min}$

$0: 0$

1

$\therefore \dot{n}$

こ

(n)

a

2

$€$ m n m

zo $m=m a$

$=\pi$

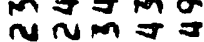

은

(2)

w

us

w定

$2 \sum$

丠占

0

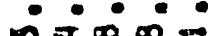

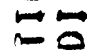

wh

$\sum$

然

x

س

00

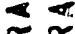

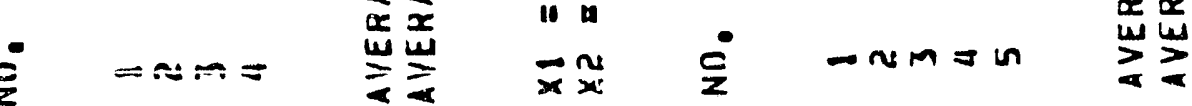



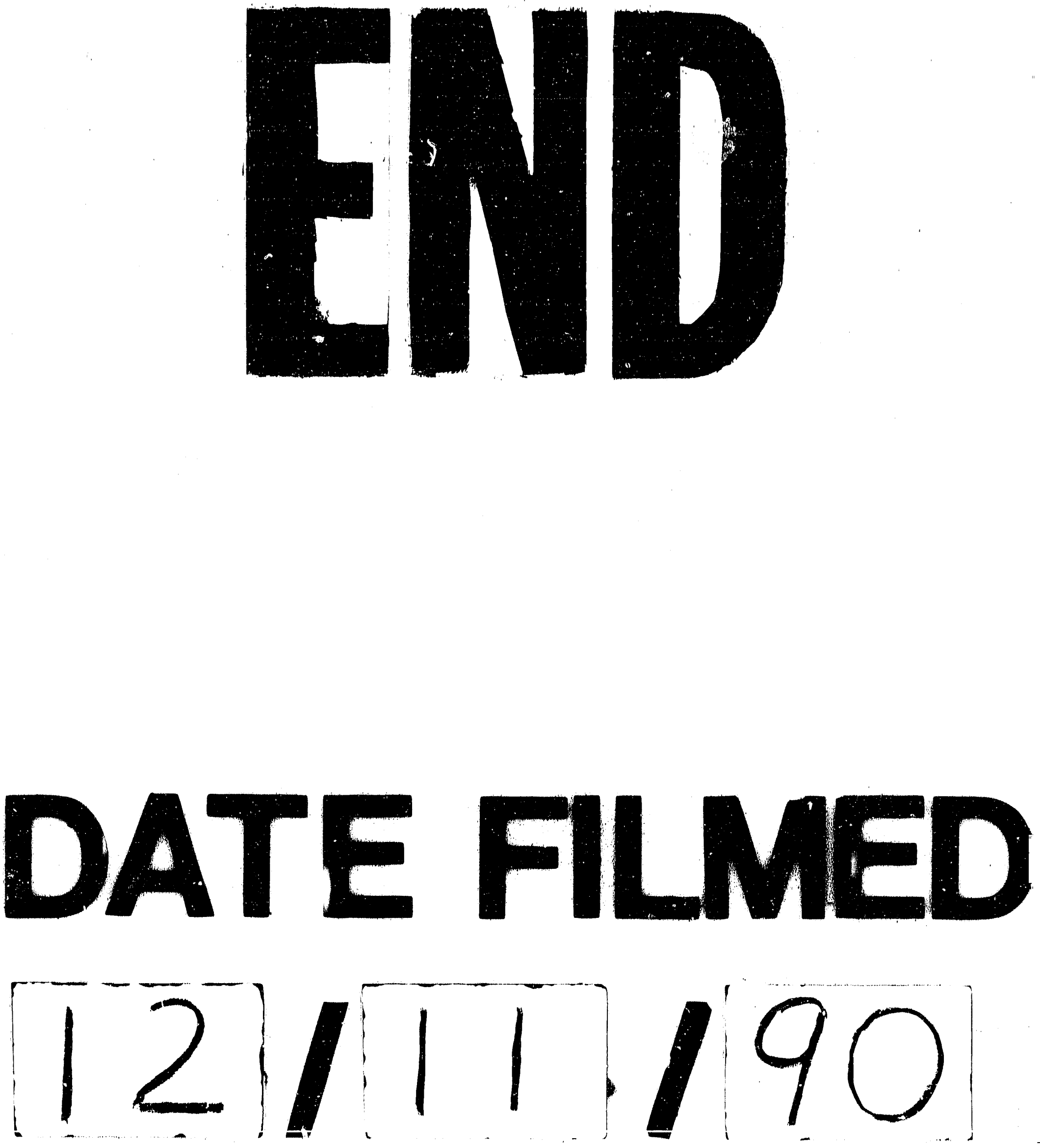
